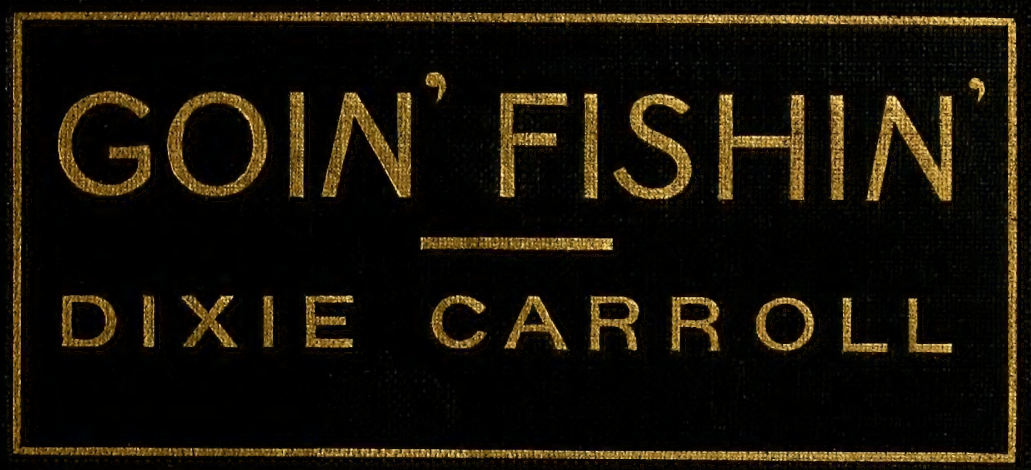




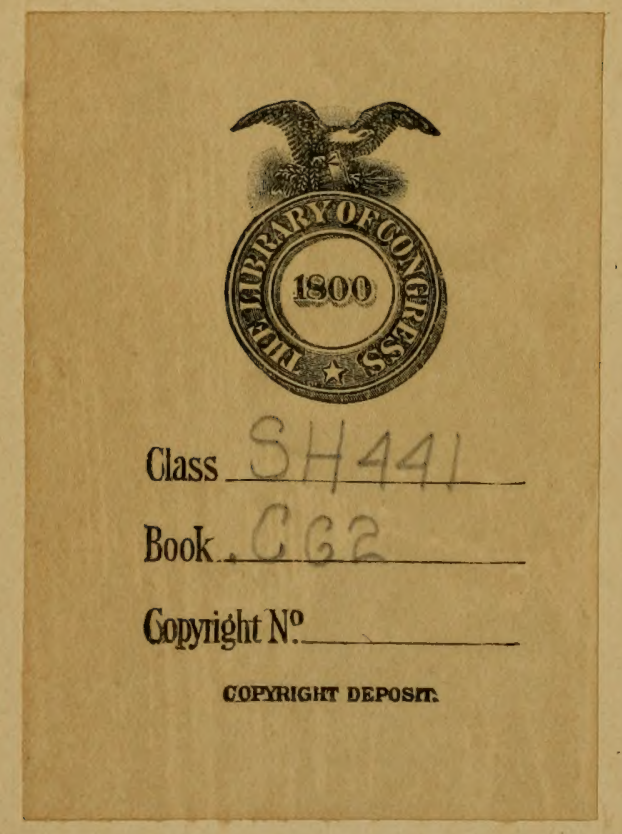






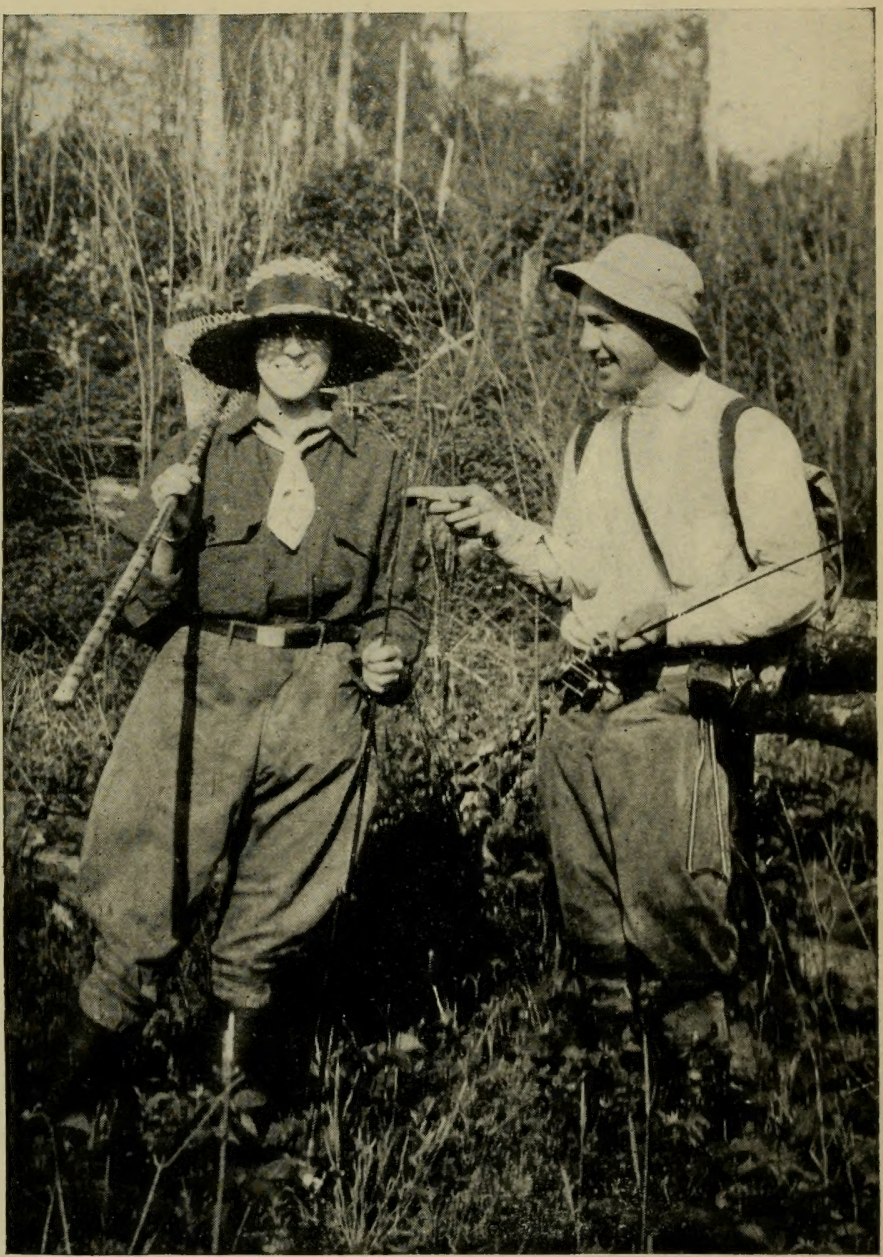

"Goin' fishing!", Oh! boy, the thrill that goes through a fellow when he hears those words. It means a trip to the out-o-doors along the woods and water trails, close to nature and her forest children, the rushing, tumbling stream, the moonbeam kissed lake waters, the wind soughing through the pines, the aroma of coffee and bacon of the evening campfire. Get the tackle ready pardner, let's go a-fishin'. 


\title{
GOIN' FISHIN'
}

Weather and Feed Facts; the Fresh-Water

Game Fish; the Natural and Artificial

Baits and their use

\begin{abstract}
BY
DIXIE CARROLL

Editor of "The National Sportsman" and Fishing Editor of "The Chicago Daily Nerws,"

President of "The American Anglers' League," Author of "Lake and Stream Game Fishing,"

and "Fishing, Tackle and Kits."
\end{abstract}

WITH AN INTRODUCTION BY

MAJOR GENERAL LEONARD WOOD, U.S.A.

AND A FOREWORD BY

WRIGHT A. PATTERSON

Editor-in-Chief of the Western

Newspaper Union

CINCINNATI

STEWART \& KIDD COMPANY

PUBLISHERS 


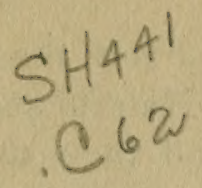

\begin{tabular}{|c|}
\hline COPYRIGHT, I920, BY \\
STEWART \& KIDD COMPANY \\
All rights reserved \\
COPYRIGHT IN ENGLAND
\end{tabular}

SEP 251920

(C) Cl.A576568 


\section{TO}

\section{ROSE AND PEARL}

MY WIFE AND SISTER.

MY "PALS" FOR A HALF SCORE YEARS ALONG

WILDERNESS WOODS AND WATER TRAILS. BOTH LOVERS OF THE OUT-O'-DOORS

AND NATURE AND TRUE FRIENDS

OF THE WILD CHILDREN

OF THE FORESTS. 



\section{FOREWORD}

\section{"Goin' Fishin'?"}

"Sure!" On a beautiful sunshiny Spring day with the buds bursting on the trees, with the first shimmer of green in the grass, with the chirp of the first robin, there comes again that craving for the lake, the river and the woodland that means but one thing: "Goin' Fishin'."

Sure we're "goin' fishin'"! We're going again to the home of the bass, the musky, the pike and the trout; we're going again armed with the confidence of landing the big one that just escaped last year. We know the log beneath which he is waiting for another juicy frog or minnow, the log beneath which he has waited for us year after year, that fighting old grandfather of all his kind, but this year is to be his last.

We have sorted up the old tackle box, have tested the favorite casting rod, have spooled a new line on the old reliable reel, and we are going forth with a keen anticipation of the battle royal that awaits us, and with an assurance of victory.

Yes we have that assurance of victory born of past defeats. We are familiar with that old game- 
ster, and are confident he has exhausted everything in his box of tricks with which it would be possible for him to defeat our purpose. His day of doom has dawned.

"Goin' Fishin'?"

Yes, going, again with Dixie. Going back to McNaughton, to Tomahawk, to Lost Land, and others of the lakes of Northern Wisconsin and Michigan where we have idled away glorious hours of Spring and Summer and Fall. Going back to again experience the thrill that comes with the strike of the gamey old musky or bass. Going back to float again into the nooks and corners of favorite waters, every one of which contains memories of past defeats or victories. Going again to enjoy the pleasures of a camp fire meal, and days and nights in the open. Going again for all that is implied in "goin' fishin'."

"Goin' Fishin'?"

Sure! When the winds of winter howl outside the windows; when the ice and sleet and snow have enshrouded the lakes, the rivers and the woodland; when pipes are lighted and the warmth of the blazing fire produces the drowsiness of a winter's evening, we're "Goin' Fishin" " with Dixie.

Then it is that we are going to dream of the days when we pushed the canoe along the beautiful streams of the northland; when we skirted the shores of wondrous lakes; when we carried a pack over 
the blazed trails; when we matched our wits against those of the gamey denizens of the waters, always in a fair fight, sometimes for us to win, sometimes for us to lose. We are going to see the vision of that musky as he leaves the water; to see the wide opened mouth, the sheen of his silvery sides; the shake of his mighty head as he fights for freedom. We are going to feel again the thrill that comes with the tug at the line; to watch the bend of the rod; to fight over again all that good fight and to experience again all the pleasure that came with the landing of a big one.

Yes, beside the winter fires we are going to visit with Joe Begosh, with Jim Friday, and others of the Indian guides; we are going to again enjoy the wondrous summer nights spent in the open of the northland where the only claim to fame is measured by the day's catch. We are going to taste again the goodies of the camp fire table at which we could enjoy a meal without fear of indigestion.

The pleasures of "Goin' Fishin' " are not only those of a Summer's day; they are year 'round pleasures, and of all our treasures the memories of "Goin' Fishin'" are the greatest.

\section{Wright A. Patterson.}

Chicago,

Mar. 18, 1920. 



\section{PREFACE}

Within the heart of every one of us burns the spark of love for the out-o'-doors. It comes to us by nature from the ancestors of other days. Of the days when these sturdy forebears carried the ax on one shoulder and the long squirrel rifle on the other as they carved their homes out of the wilderness.

In some, the spark lies dormant awaiting the call that eventually will come from the red gods of the outlands, the call that will take them back to nature, while in others the spark has fanned and flamed into a burning desire to make us wish to throw off the shackles of civilization with its prosaic, regulated workaday life, tear the shirt wide open from our neck and gallop out into the land of heart's desire, along woodland and water trail, there to commune with nature and her wonders.

Once in the open places of the outlands, under the brim of our old felt hat, our spirits are back with the days of our ancestors and the good old primitive love of the stone ages trickles through our skin and the out-o'-doors takes us back to her 
bosom, like the long lost children we are, there to sooth us with the whisper of the wind as it soughs through the pines, the laughing purl of the tumbling, running stream, the quiet murmur of the wind-tossed lake waters that try to climb the beams o' silver winking down from the moon in its blue-bowled setting.

I am glad that the love for the out-o'-doors burns like an unquenchable volcano within my being and that it has from the earliest moments of my life, that I recall. Much of the early development of this love for the quiet places is due to my father and mother, both keen lovers of nature and the open. Much of the outdoor life, fishing and hunting, game fish and wild animal life came to me through experiences with my father, who as a youngster, left the home trails of the Blue Ridge country and led the life of a frontiersman for a number of years, making the long trek along the old "Sante $\mathrm{Fe}$ Trail" four times, in the days when making that trail was a man's-sized job for a youngster. Driving a tack at thirty paces with his old "forty-four" was a record he set up for me and one that I am still driving at.

It has been a pleasure to me to write this book with the thought that it may help a little in making the quest of the game fish more enjoyable to the reader; if it helps fan the spark into flame and 
brings the call of the out-o'-doors to you, the pleasure will be doubled.

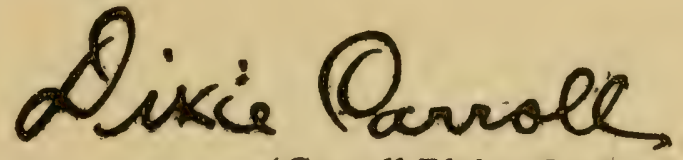

(Carroll Blaine Cook)

Timberedge Lodge, McNaughton, Wis.

Nov. 27, 1919. 



\section{INTRODUCTION}

Some one has said that it is not all of fishing to fish nor all of hunting to hunt. The spirit of this is understood by every sportsman worthy of the high name. We go into the open to get not only the satisfaction which comes from a fair day's fishing or shooting but that spiritual satisfaction which comes from companionship with Nature. There is something in the freedom of the fields and the fragrance of the forest which appeals to the man who is a sportsman and not merely a killer. The campfire has its allurements. Its smoke is a sweet smelling savor. The tramper of the fields and the fisherman of the streamside are better men and better citizens because of these avocations which they love.

The fisherman is the companion of Nature and Nature makes a companion of him. I have heard a story of a man who went fishing for trout in the streams of northern Michigan. He came back and was asked what he had caught. He said, "I forgot to fish because a hermit thrush was singing."

This is the spirit of the whole thing. There is a joy which comes from the tingling of the rod and the sound of the splash of the troubled waters and xiii 
there is likewise a joy in a good catch, but there is no joy in a basket that is overfull. Moderation and a fixed regard for the legal limit are the things for which the true sportsman stands whether he be fisherman or gunner.

We cannot kill our game birds and our fish and still have them. Something is due to posterity. Our children and grandchildren should not be deprived because of our gluttony of the opportunity for the sports which we follow and which make for manhood and citizenship. Let us see to it that posterity can continue to follow them. None of us has any love for the butcher of our game birds, our game animals and our game fish. No slaughterer knows anything of the true spirit of the sportsman. He has no joy in the open life. He is simply a killer with no soul beyond the killing.

The real sportsman finds a true interest and a true zest not in wantonness but in the securing of his quarry in a way which will give to it a sporting chance. He pits his own skill against the skill and inborn intelligence of the game. He has nothing in common with the pot hunter. In other words, the spirit of the true fisherman and the true hunter is one of fair play.

Our American sportsman has that keen appreciation of life in the open, of the campfire and of the rough but wholesome food of his own cooking. $\mathrm{He}$ loves to test his wits against the instinct and clever- 
ness of the children of the wilds; his strength and endurance against theirs and he has an instinctive dislike of slaughter for slaughter's sake.

Men of the outdoor type, fishermen and hunters, bring a healthy influence into our public life. They are freer from the spirit of intrigue and the narrowing influence of sequestered living. They can bring into our public life that spirit of freshness and vigor which is much needed.

I believe it to be the object of this book to preach the gospel of the open air, of moderation in the pursuit of the sport which we love, of the conservation of the wild life and of those other things which appeal to manly men who love Nature in all her moods and who seek her society for the joy that it gives them. With this view of it I commend it.

LEONARD WOOD.

Chicago, March Ioth, I920. 



\section{CONTENTS}

Get the Tackle Ready . . . . . . . . ${ }^{\text {Page }}$ Playing the Fish . . . . . . . . . . 5 The Bait-Casting Plug . . . . . . . io Defense of the Plug . • . . . . . . . I5 Natural Batts . . . . . . . . . 20 Stream Fly-Fishing . . . . . . . . 25 FEed Facts . . . . . . . . . . . . 30 Give Your Bait a Chance . . . . . . 35 Bait-Casting Lines . • . . . . . . . . 40 Accuracy IN Casting . . . . . . . . 45 The Reel and Backlashes . . . . . . 50 Fishing the Spoon . . . . . . . . . 55 The Crawfish as Bait . . . . . . . 59 The Surface Strike . . . . . . . . 64 The Minnow as Bait . . . . . . . . 69 Meet Mr. Wall-Eye Pike • • • • • . 74 TO THE MUSKY . . . . . . . . . . . 79 Spooling the Line. . . . . . . . . 83 The Frog as Batt . . . . . . . . 88 The Pike Family . . . . . . . . . . 93 Handling the Rod • • • • • • • • • . 98 Hot Weather Bassing . • . . . . . . . IO3 Among the Catfish . . . . . . . . . 108 When to Go A-Fishing . . . . . . . . 113 


\section{CONTENTS}

The Floating Bass Bug • • • • • • • • II8

Tail-End Trouting . . . . . . . . . 123

The Bass Family . • . . . . . . . . I 28

The Musky Game . . . . . . . . . 132

Fall Fly Fishing • • • • • . • . • . I 37

The Fall Fighter . . • . . . . . . . 142

Thank the Pickerel . . . . . . . . . I46

"Busting" the Rules . . . . . . . . . I5I

Skittering for Pickerel . . . . . . . 156

Care of the Fly Tackle . . . . . . . . I6I

KeEPin' Up the SUPply • . . . . . . . 166

What Fools 'Em . . . . . . . . . . 169

Trout vs. Small Mouth Bass . . . . . 174

Fishing Weather . . . . . . . . . . I77

Colors of Artificials . . . . . . . . . 182

LARge-Mouth vs. Small-Mouth . . . . . . 187

Among the Little Fellows . . . . . . 192

CANoeing the UPPeR Wisconsin . . . . . . 197

LeAVES FROM AN ANGleR'S DiARY . . . . . 201

Batt-Casting Rods . . . . . . . . . . 220

The Steel Bait-Casting Rod . . . . . . 230

The Outboard Motor in Fishing . . . . 242

Footwear For THE OUtDoORS . . . . . . 251

A Bit about the Camp Commissary . . . . . 263

Head Camp Talks . . . . . . . . . 275

Where to Go A-Fishing . . . . . . . 329

Wisconsin Fishing Waters . . . . . . . 330

Minnesota Fishing Waters . . . . . . 338

Pacific Northwest Fishing Waters . • . 344

Canadian Fishing Waters . . . . . . 35 I 


\section{GOIN' FISHIN'}

\section{GET THE TACKLE READY}

Nearly every angler is a tinker, a handy man with the screwdriver and the odds and ends of the family tool kit. Some of the boys take naturally to tinkering with the reel and tackle, while some of them have a nervous pair of hands that simply itch to take things apart. The tackle of the bait caster consists mainly of the rod, reel and line, together with an endless assortment of plugs, bucktails, spoons, spinners, swivels and many odd baits that he has doped up himself.

The rod, if it is split bamboo and has had a good run of work during last season, likely has a couple of ferrules loose. The top guide may have worked into a little play, and as a general thing the varnish has cracked in places. Give it a thorough overhauling, cementing on the ferrules, rewinding any loose wrapping of silk, and then give it a coat of varnish. Let it dry for a week and then put on another coat, so that when the season opens this fine part of the kit is ready for the first fair fishing day that comes along. 


\section{ALWAYS READY FOR FISHING}

Many times the first fine fishing day comes bobbing along unexpectedly, and finds the angler grabbing the rod that should have two or three hours of work and attention before it opens the season. And the loose ferrule may mean the loss of a fine game fish, while the cracked varnish may mean a dampened strip of bamboo that will put the rod completely out of commission. The real angler takes good care of the tools of his trade; in fact, he is judged by his fellow sportsmen by the shape in which he keeps his tackle, and a few hours during the layoff days pay big dividends on the life of the favorite split bamboo rod, which, if good at the start, should last a lifetime with a little attention and care.

The steel rod, of which there are many in use in the bait-casting sport, needs far less care than the split bamboo. It should be wiped dry each day while in use, the same as the finer split bamboo, and it is well to wipe it with an oiled cloth, using a little three-in-one oil. This prevents rusting, which saves the enamel from cracking off the rod. Then hang it up in its little case out of reach of the kiddies so they do not draw on it as a gun or baseball bat on a rainy day.

\section{REEL NEEDS ATTENTION}

There is no part of the bait casters' tackle that should be given more care than the reel. Upon 
this tool the greatest share of the quality of the cast depends. A reel that jams or rides out of plumb is a great little cause for the backlashes that visit, more or less, all of us on the waters.

If the reel happens to be one of the excellent take-aparts, then cleaning and oiling it is a simple proposition. When the reel is taken apart it is a good plan to give it a bath in kerosene, wiping off the hardened oil that has caked on the spool and end plates and then giving it a thorough oiling with a good light oil, placing a small daub of vaseline on the cogs of the gears. This will keep it in fine shape during the resting period and assure you that it is ready for the emergency trip of the opener.

If the reel is one of the high-strung affairs that has been finely balanced by the maker, one of those loving wonder-workers of the reel family, and you do not happen to be of the tinkering class, do not take it apart yourself, but send it to a good reel repairer and have him give it a little attention.

A fellow can put a finely balanced reel out of commission easier than any other piece of outdoor kit and when one has paid high for a fine tool why take any chances with it? Finally, wrap the reel in a slightly oiled cloth and place it in the leather reel case, which is a good insurance against knocks and bumps which could easily put it out of smooth running order. 


\section{SAVE THE OLD LINE}

If the bait-casting line has been given good care during the season it should be in fair shape for use the following one; that is, as a second line at least. If you have alternated the ends in casting each day and dried the line each evening after use you will be surprised at the strength still remaining in that piece of braided silk.

Take the line off the reel and wind it closely on the original spool. I have found it a good plan to roll a piece of tinfoil over the spool, which keeps the line clean and dry until needed. It is not a bad idea at all to run the line through a slightly oiled rag before winding it on the spool.

\section{SHARPEN THE HOOK POINTS}

The plugs should be gone over and the points of the hooks sharpened with the small file usually tucked away in the box. A sharp hook point at the right time means an easily set strike in the tough old mouth of the game fish. A drop of oil on the swivels makes them turn better and keeps them from corroding and stiffening up.

Taking a slant at the odds and ends of the outfit, such as sinkers, snaps, leaders, etc., shows you just what you need among these little "fellers." 


\section{PLAYING THE FISH}

"Playing the fish" is a phrase the beginner hears when the "regular" spins his fishing stories after getting back to civilization. And it is a mighty important part of the game; in fact, playing the fish, and playing it right, is where the real sport of fishing is found.

To simply hook a game old bass and then pull it in as fast as you can possibly turn the reel handle, or to drag it in hand over hand if you happen to be trolling with a hand line, is about as much sport as to have your guide row like blazes and down a man's size musky while you sit back and hold the rod.

This is merely catching fish, and to the fellow who is satisfied with yanking them in that way this story will not be very interesting. To the good scout who wants to get a full measure of enjoyment out of his fishing trip and at the same time give the game fighters just a little chance for their "white alley" this dope will hit the right spot. To the regular, who plays the game right from every angle, it will be old stuff, but perhaps at that a point or two may be gleaned before the last period is reached. 


\section{LET HIM TAKE THE LINE}

As a general thing, right after the strike of the game bass, musky or pike, and after you have set the hook with a switch backward of the wrist, the fish makes a decided effort to start for other parts. This is the start of playing the fish; let him go for a run, but keep a slight pressure of the thumb on the reel spool so that he does not have an entirely free line. Let him take the line, let him run, bringing the pressure down steadily until you have slackened him in his flight and have just enough arch to the rod to make him pull a trifle. This arch will eventually be the springing pull and pressure that will kill the fish while you play him.

Naturally if the game fellow makes a break for the weeds or underwater snags and logs you will shove on the pressure more speedily and begin reeling in. This in order to work him out to cleaner water where you can play him to your heart's content.

If you have worked out to cleaner water you can give him the line and let him take it in his teeth for the length of his run. Then the sport is ripping.

The line sings through the water in a tune that is music to the angler and something to go many miles to hear. The main thing in giving the fish a chance to run the limit, is to keep slack out of the line. The thumb must quickly detect the slowing 
up of the pull and then you must quickly reel in the line. One of the stock tricks of these masters of water strategy is to come back on a rush for a short run and then up out of the water for a shake that will send your lure or bait flying in the air, and the clever rascal will kick off to other waters.

\section{KEEP THE LINE TAUT}

Should the small-mouth bass or musky get you unawares and jump up to the top for a shake, keep the line taut, but as he lands back on the water let the rod go forward and give him just a little slack as he hits the surface. This is as essential as keeping the line taut at the beginning of the leap as the hook is often torn out of the mouth when the game fish lands back on the water with a taut line. A quick taking away of the slack as he doubles back to you, holding him taut as he makes his leap and giving him a trifle of line as he hits the water, is the real way to save your fish when he tries to dance on the surface.

During the first few minutes of the fight do not try to work the bass too close to the boat; reel him in to within, say, thirty feet, then if he shows any inclination to take the line, let him run again, bringing him back a little closer each time. On each run make him take the line a little harder, put just a little more pressure on the reel spool and arch the rod a little more. This tires him out and after a 
few long runs he will come in more easily and each run will be shorter and less snappy.

\section{OFTEN HEADS UNDER BOAT}

Often at the first sight of the boat he will make a straight header down and under it. Here your work is cut out for you, and unless you show some speed he will get a right angle on your rod and snap it against the side of the boat. Many a rod has been broken by a foxy bass or musky by this stunt. As he makes this run, quickly swing the rod around the end of the boat and bring him promptly to his senses by shutting down the thumb pressure before he beats it for strange waters, which are usually full of snags.

After you have worked him close up to the boat and he seems to have just a little too much fight to make it safe to net him, a good system of playing him until he tires completely is to give the rod a figure eight movement at arm's length for a few minutes. This little game of swimming him around in double circles works him right off his feet, and he is soon ready for the landing net.

\section{HEAD HIM TO THE NET}

In using the landing net, make it a habit of handling one that has a good-sized hoop and a deep net so that your fish will drop down into the net and not hang over the sides. This gives him a purchase and 
ofttimes he makes a last kick that is full of life and flops out into his home waters to tail away. And in netting him do not push the net toward the fish; it scares an honest-to-goodness game fish to treat him that way. A scare at the right moment means a victorious fight of short duration but generally of speed enough to take you unawares, with the rod in one hand and the net in the other. 


\section{THE BAI $\Gamma$-CASTING PLUG}

In the short space of a little over twenty years the bait-casting plug has splashed right up to the front as the most popular lure for the game bass, especially in the early season and the tail end of the season, after the hot weather, when these merry top-of-the-water fighters are feeding in the shallows. Even in the warm weather the plug has its innings early in the morning and late in the evening, with a regular winning play during the night casting, be it the moonlight variety or the ordinary black night with nothing but the stars to give a little light to the casting stunt.

When the short bait-casting rod broke into the game out here in the midwest section the plug was the natural consequence. Previous to the five-foot rod the eight to ten-foot live bait rod was the only casting tool besides the lighter fly-casting rod, and the game of fishing $w$ limited. When the short, stubby bait-casting rod :an up to the barrier and started down the stretch the rest of the fishing game acted like an "also-ran."

The sirort fellow simply trotted right up into the front and sas stay $d$ there ever since, and he who 
made it popular was the first angling artist that whittled out the father of all the wooden plugs. Since that happy day thousands upon thousands of fellows have answered the call of the waterways and thus have tapped nature's stores for wonderful times and much healthy recreation.

\section{FATHER OF THE PLUGS}

There is a little story on the origination of the plugs that sounds as though it might be true at that. The legend tells us that way back in the misty past a disgusted and disgruntled fisherman was sitting in his boat making sundry and divers remarks about fish, all the way from the big musky down to the smallest minnow, on fishing luck and the value of a horseshoe as a pocket piece on a fishing trip. All this because the fish were off their feed and would not bite.

Finally in disgust, and probably with a little show of temper, this gay fisherman tossed an empty cigarette box on the water at a rippling little break on the surface. Then the big thing happened. It looked as though an unseen hand had reached up out of the depths and punched the empty box four feet in the air. Naturally the fisherman was a trifle astonished, regardless of the fact that he had consumed a lot of bait during the day. But as the old box tossed along on the little wavelets something lunged up again, and this time he saw what it was. 
A regular old grandfather of the bass tribe had smashed up and struck the gayly colored cigarette box with a snap that sounded like music to the angler.

Right away this live wire of the waterways recovered the box and tied onto it a couple of hooks, connecting them with his line, and then and there he started the thousands of highly colored wooden baits that are now dangled so luringly before our eyes when we chance to pass a tackle store. And brave, indeed, is the bait caster who can pass a window full of these multi-shaped affairs without stopping to give them the double-o. This old cigarette box had blossomed out into a line of baits that have put fishing on the map.

\section{GIVE THE PLUG A CHANCE}

There are many plugs, and they come in every variety of color, and every last one of them will get the fish if you give them half a chance. The one big trouble in the plug game is that a fellow carries so many of them that he is continually changing baits and never gives any one of them half a show for their white alley. If you would start out with one plug and play that plug all day you would get fish with it, but giving it a dozen or so casts and then changing to another style and color, with the thought that the first one was not what the game fish were looking for, is sure the wrong way to play 
the plug game, and at the same time is not playing fair to the plugs.

In a few hours' fishing I have known fishermen to change plugs a dozen or more times, while I have fished with the same old plug and got twice as many strikes as my companion. This was not because I was such a wonderful fisherman, but because I had learned the lesson of keeping at the casting game and not spending half my time changing lures. When you figure that a strike on 50 to 70 casts is as good an average as most fishermen can count on, the time you lose in monkeying with a bunch of plugs is merely time taken away from casting for the fish, and a good rule to follow is to cast steadily if you expect to have use for your stringer.

\section{KEEP THE PLUG MOVING}

As I have said before, any one of the many plugs will get fish. Some of course have a more lively wiggle or darting swim than others, but any of them will interest the game fish if you keep it moving in the water. To interest a fish a plug has to have motion, movement. To let it lie dead on the water kills its value as a fish lure. Many strikes are made by the bass the instant the plug hits the surface. Often the bass starts, while the plug is in the air; on his way to the point the plug will strike. This means that the fisherman must start reeling in the plug the moment it lights on the surface. In fact, 
by giving the rod a slight switch backwards, the plug can be started homeward, and by quickly reeling it in it continues in a darting swim back for the next cast without developing any lost motion and thus killing the value of that cast.

In using the plug for bait it is necessary to strike the fish the instant the fish strikes the lure, as they are quick to disconnect with the chunk of cedar if you fail to set the hooks promptly, and strike with enough steam to sink the hook over the barb. 


\section{DEFENSE OF THE PLUG}

Every now and then some one comes out with a line of argument that the plug is not a sportsmanlike lure and that all plug users are out of the sportsman class. It seems that the use of the plug by a great army of fishermen has annoyed mainly some of the boys who toss the gayly colored fly to the trout family and because the pluggers go right along in their quiet way enjoying the plug-casting game and do not immediately throw the offensive plugs into the ashcan these postgraduate anglers are real peeved.

Plug casting and catching fish via that method is not child's play nor is it a thing to learn in a minute, as many of the erstwhile highbrows of the fishing brigade would lead you to believe. If any fly caster who has never tried the plug-casting sport thinks that it is a simple operation, let him try to imitate a clever caster of the wooden plug. An expert at this kind of fishing particularly must be a good judge of distance so as to place the plug within a reasonable distance of the spot at which he casts; he must at all times during the cast have per- 
fect control of the reel and the line running therefrom, for both of these must have uniformity of action.

When the eye tells the caster that the plug has winged through the air the proper distance to drop into the pocket in the lily pads, then the thumb must be clamped down sharply on the line on the reel in order to stop the spinning spool, otherwise the caster finds a reel full of tangled line, innocently called a backlash. This sounds easy and simple. To be convinced that it is an art, all the beginner needs to do is to try it.

\section{USE SINGLE HOOKS}

The only logical objection to the plug from a sportsman's viewpoint would be on the number of hooks thereon. Many of these lures, as marketed, carry from three to five trebled hooks. These hooks are not only unnecessary, but they are a bother and gather up all kinds of weeds and snag whenever there is a possible chance, and even sometimes when they don't seem to have any chance at all.

From my own experience I find the plug with either one single hook at the end or with one at the end and another single attached to the forward eyelet far more effective in setting the hook on the strike than a plug so armed with trebles that it appears all hooks. It is a very easy matter to rearrange the hooks on a plug, and this removes all cause 
for any objection that they are not a clean, sportsmanlike lure.

\section{MAKES A SURFACE FIGHT}

One big reason why the plug is so popular with a great many fishermen is, without doubt, the fact that the fight of the bass from the very strike is a surface affair, the plug caster having the undiluted pleasure of watching the game fish do his tricks up where he plays right in the center of the screen, as it were. For that reason the surface or semi-surface plug is generally the most popular.

In the surface fight in the plug game it is necessary to keep your eye on the fish in order to counteract with tackle skill any trick of the game one. Slack in the line must be taken away speedily and on the break of the water when the bass goes right up in the air because of slack in the line, a fineness in touch is necessary, so that you do not take away too much of the line and allow him to land back on the water with an entirely taut line, as the hook is easily loosened if such is the case.

Keeping the eye on the fighting fish gives a fellow a lot of thrills, but it is a trifle of a hard job to reel in the line evenly on the reel spool without pulling your eyes back to that little tool of the trade. It takes some practice to be able to reel in a line evenly and smoothly without watching the operation and to eliminate the trouble a reel with the level-winding 
attachment will take away the necessity of becoming an expert at this tedious, finger-tiring work.

\section{STRIKES BUT ONCE AT PLUG}

The bass strikes but once at the plug and is quick to find out that it is a base deception in the way of feed. This means that the plug caster must strike quickly as soon as he feels the first pull of the bass or sees the attack. And let me say here it takes some practice to be able to set the hook every time. In fact, it will be many times that the plugger's hook does not go home enough to even retard the bass in his meanderings, while the single hook on the live bait will be taken by the fish, carried for a short distance, and then swallowed, after which the bass will swim away and hook himself way down in the stomach.

Hooked in this way, the bass does not feel much like making any fight at all, because the sharppointed hook is digging into his vitals, and he comes along most easily. However, when hooked in the mouth, which is invariably the case with the plug, he fights like a terrier, and has free action to use any of his stock tricks to throw the plug in his effort to get free.

From this angle alone I feel that the plug, with the single hooks, is far more sportsmanlike than the live bait on the single hook, because it in the first place must attract the bass to the surface to strike; 
the strike must be followed immediately by the angler's strike to set the hook and the hook is in no way an interference to his effort to fight his way to freedom.

In fly fishing more than one hook is permitted, of ten three flies being used on the cast. With two hooks on a plug, it would be an extremely difficult job for a bass to hook himself on two hooks diametrically opposite. In fact, he would have to assume the shape of an eel to do so. 


\section{NATURAL BAITS}

Classed among the natural baits of the game fish are all those little fish, frogs and insects that make up the daily menu of the bass, trout, muskellunge, pike, pickerel and wall-eye pike. The fact that they are natural feed places them in the list of natural baits with which to inveigle the game fish to your hook.

Of all live natural baits the minnow rightly comes first because it is the greatest source of food supply. Next comes the frog, then the smaller pan fish, such as the perch, sunnie, bull-head and such, then the crawfish; following that we have the insect group, made up of the grasshopper, cricket and butterfly; then the worms, wood grubs and helgramite.

Ofttimes the small perch will make an interesting bait for bass as a casting lure in lake waters, especially out in the deeper pools. For this style of fishing cast out into the pools, allow the perch to work low in the water and reel in medium slow. A small spinner will help the perch bait as an attractor of the bass, and if you clip off the top fin with a sharp knife the bait will be more effective. The cutting off of the fin will not injure the perch and makes 
the bait more easily handled by the bass, as the sharp spikes in the fin are out of the way and the bass can swallow your bait without juggling it around to avoid the sting of the spikes.

\section{BULLHEAD FINE FOR STREAMS}

In stream fishing for the bass, the ordinary little bullhead is a good bait and has been overlooked by a lot of fishermen. Hook up through the lips and let them down near the bottom to swim around and attract the big bass that so often wait close to the bottom of the pools for just such a bait to go ambling by. It can also be used to cast into the edges of the riffs and in the eddies alongside of the swifter waters of the riffles and rapids or around the rocks that stick up out of the water. These spots are generally the lounging places of bass on the lookout for feed. And it is usually a big bass that preempts these good feeding grounds and lords it over the favored spot where the food supply is excellent. That is what makes them big and scrappy. They feed well in such places and are willing to defend themselves against other members of the family that try to steal their feeding grounds.

The grasshopper is a wonderful bait for bass in the streams and the best variety of hoppers are those gray or dusty colored fellows with the spread of yellowish wings with black markings. It is easy to get a fair supply of these by using a landing net 
to capture them. The best time to use them is when the water is clear and fine toward the end of the season when the usual feed, the minnow, has been fairly well eaten up by the hungry bass. Toss a hopper out alongside of a log or stump, along the cut-in banks where the grasses grow close to the water, and let them ride down along the swifter water at the head of the pools.

\section{HOPPER A FLOATING BAIT}

Naturally the grasshopper must be handled as a floating bait to be really effective and to use him with a fly rod is the real sporting proposition. Before a lot of the boys ever thought of making the now famous floating bass bugs, the hopper was the real floating bass bait. If you cast with the fly rod and fly, take a little chance with the hopper, casting up and across the stream and let your hopper float down stream naturally with the current, placing it so that it will float down alongside of a bowlder or log that may be breaking the surface of the water. If this choice bait does not scare up a strike there certainly is no bass holding down that spot.

The grasshopper to be effective must be lively, and naturally lively at that, so do not take away any of his kick by running the hook through his body. Simply place him along the shank of the hook and tie him on with a short piece of thread. As the 


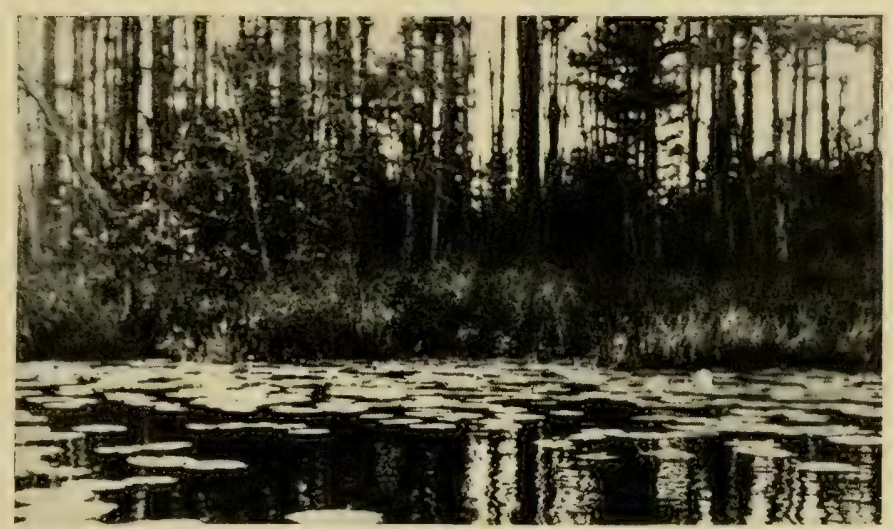

Among the lily pads is the real home of the large-mouth bass, and the way to interest them is being able to land your cast in the small open water, or pockets, among the pads. Two bass were landed from the weed pockets right after this snapshot was taken.

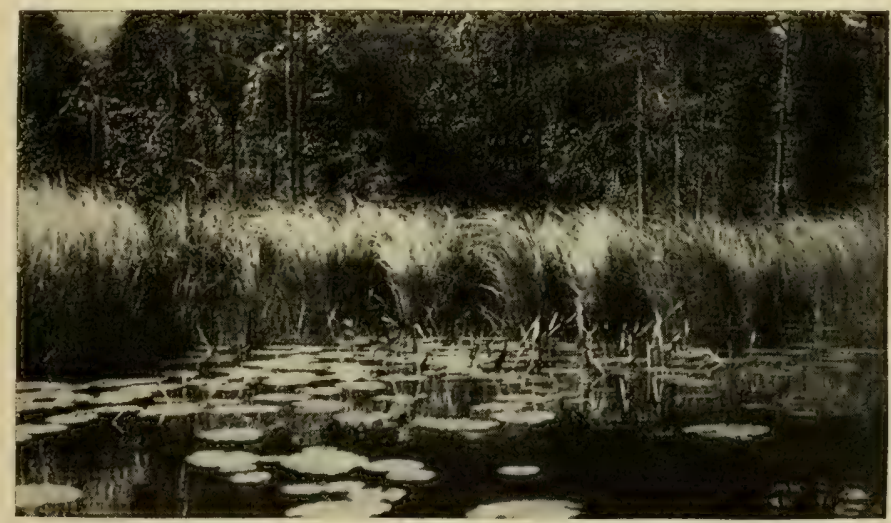

A cast, dropping the frog in the lily pads off the edge of the rushes, was too much for a sixteen-pound pike. The pike seem to dote on the frogs and minnows off the edges of swampy weedy waters, where the water backs under the wire grass. 

bass takes the hopper from the surface in the same quick strike of the fly, it is necessary for the angler to strike him immediately on the rise. Strike sharply at the first rush or he gets your bait and nothing else. Of course, by tying the hopper along the hook the chances of losing the bait are lowered, yet it is necessary to strike quickly and set the hook without delay or the bass will blow out the bait.

\section{SMALL CRICKET IS GOOD}

The small black cricket with the piping voice of night-time is a good bait for the smaller streams and should be used on a very small hook, say a No. 8 size. Tie him on the hook around the body and shaft, leaving the legs free for kicking purposes. Use him as a floating bait the same as the hopper and work him well in along the shore of the deep pools, near the stumps and backwater of the coves and around the brush heaps in the water.

The white wood grub found in the decayed logs and stumps and under the logs on the ground is a fine bait for bass and wall-eye pike. Run the hook lightly through under the skin and along the entire body, in this way circling the hook and part of the shaft. Let the grub down in the pools, using it as a still-fishing bait, giving it a little motion by raising and lowering the tip of the rod. It takes a very much overfed bass to overlook this bait when dan- 
gled within sight. They have a failing for this soft piece of feed that does not come their way every day.

The helgramite, the black scaly fellow with the sharp pincers, is another good stream bait and works well in the swifter water at the head of the pools. This is the natural place to use them, as they live in the riffles, under the rocks, and wash down into the pools from the riffs. Work them well down toward the bottom and in hooking them run the hook in under the scales at the neck and along the body out through the other end. 


\section{STREAM FLY-FISHING}

The real sport of sports of angling is without doubt going after the small-mouth bass with the fly rod along a stream. This great little warrior of the running waters puts up a wonderful fight and when brought to the surface with the feathered hook he can make things lively for the angler who handles the long limber fly rod. The cool waters of the streams give him great vitality and his fight is full of pep from the instant he takes the fly. And his fight from birth against the current of the stream develops a set of fins and tail muscles that just naturally makes the scrap rapid fire and strong all the way through.

The small-mouth bass of the stream is not as much of a traveler as his brother of the lake waters, and a big part of his life is passed in learning all the refuges and hiding places of the stretch of water in which he swims. This is very valauble knowledge for him when he happens to meet his Waterloo on the hook, and he is quick to take advantage of every snag, underwater root or log in an effort to break the line. Some of the boys who have not followed him along the streams think that 
this wonderful knowledge credited to his nibs is a little small-town talk, but for a real thrill give the stream the up and down a few times; you'll sure like it, and be a regular at this sport for the balance of your natural life, and probably along the golden streams after you make the long trail.

\section{WHERE THE BIG ONES LIVE}

Often you will find a big bass who had discovered a home of his own and likes it; you may try for him this season and the next, get a strike, lose him, and knowing that he is there, make a bee-line for that particular spot every time you fish that stream. Although you do not land him, you know he is there, and you are drawn to that part of the stream with the hopes of eventually getting him, and if you do, oh, boy! you tell about it for the rest of your life.

This home is often found at the head of a pool, where the swifter waters run in and where the bass has found the minnows easy picking, as well as the helgramites that roll down along the bottom. He has pre-empted this spot, and defended it against all comers. Being the big boss of those waters and having food fairly plentiful, he has grown large and husky. Or the home may be alongside of a boulder that breaks the surface, the minnows being easily nabbed as they swim around it, not to forget that usually the swirl of waters forming an eddy 
below the rock makes a spot where all the surface feed floats on its way downstream.

\section{SOME LIKELY SPOTS}

Under a cut-in bank where the stream makes a bend and has washed out a neat hiding place; among the roots of a large old tree along the shore, or at the base of the riffs or rapids are other likely spots where you may find the big one you are always hoping to mount and show as a trophy of your skill as an angler. As you follow the stream you soon acquire a working knowledge of where to find the bass, and each stream is a new field to study and develop. I have fished a number of streams for the last ten years, and each trip along these streams is more interesting than those gone before. There is nothing that will fill the stringer quicker than knowing the waters you fish, assisted, of course, by a good understanding of the habits and haunts of the bass.

Early in the season is not as productive of good fly fishing as a little later, as the fish do not feed from the surface until the insect life along the stream has hatched and is on the wing. Much pleasure can be had early in the season by fishing with bait, either the minnow or the lowly angleworm, known to most of us as the "fish" worm of our early days with the long cane pole. Some fishermen look with scorn upon the worm, or "garden 
hackle," as they term it, and think that fishing with it is not ethical, nor sportsmanlike, yet these same fellows do not scorn to slip a few worms on the hook early in the season when they cannot for the life of things raise the game fish up to the fly. That is, of course, if no one is looking, or they happen to be around a bend with their pal just out of sight. Many of the early season stories of getting the big ones with the fly are bunk; they are usually brought to the net with a nice fat gob of worms, regardless of the wonderful word pictures painted by the ultrapurist of the fly brigade who brought them home.

Why there should be any objection to using the natural feed of the bass when he is taking that feed is more than I can assimilate, and especially if you take him on light tackle and do it in a clean, sportsmanlike way.

\section{STREAM MUST BE IN CONDITION}

Stream fishing with the fly is good when the stream is right, and it is well to keep in touch with a local resident along the streams you fish and have him keep you informed as to the condition of the water. Many fellows have waded much water without very gaod luck and have at times come to the conclusion that stream fishing is not what it is touted to be. Probably they have hit the waters after a rain when the stream was high and roily, carrying the usual muddy coloring which makes successful fly fishing 
almost impossible. Forming an opinion of stream fishing from a trip of this kind and then giving that angle of the sport a cold shoulder will lose you the real sport of fishing. When any stream is "just right" and you have the dope from a native, hit the train, son, and have the time of your young life. 


\section{FEED FACTS}

The deeper a fellow goes into the study of fish and fishing the more interesting the research becomes, and he simply wants to delve further into the mysteries of the game-fish families. At the present time we know quite a lot about the different species of fish, their habits and peculiarities and the best methods by which we can fool them into the landing net, yet water conditions vary in some places. We often find that our ideas are knocked galley west by something in nature's handiwork in some particular lake or stream that all but chucks our knowledge in among the past performances, leaving only the most basic facts upon which we can start a study of the fish in such places.

In some lakes you can toss a frog for hours, yes, weeks, and not even cause a ripple on the surface from a strike, while if you happen to have the right tip, by throwing the game fish a certain colored plug, or a minnow, perhaps, you have a strenuous time taking them off the hook. May be the lake right over the ridge, by a short portage, is pie for the frog as bait and not very good for the minnow. Such is the work of nature, and until a fellow makes a 
study of the waters he fishes and digs out these peculiar desires of the fish of said waters, he generally does not break down from the weight of the fish he catches.

\section{FISH HAVE DIFFERENT TASTES}

The reason for this variance in the tastes and desires of the game fish in different waters is something that has not been determined by our scientific friends. It may be that there are no frogs around the shores of the lake in which you can not interest the game fish by throwing them the green-backed little hopper, yet I have known waters along the shores of which frogs lived and thrived and the bass of those waters never winked an eye when you tried to get better acquainted through feeding them choice frogs, and men who have lived along these lakes for many years have never known the fish to come through with a strike via the green-backed hopper route.

While on the subject of frogs as a bait, who, of the angling fans reading this page has ever found a frog in the stomach of a bass they have landed? During many years of fishing in many localities where I have found the frog a rather good bait for bass, I have never found a frog in the stomach of one of these fish, either whole or in a partly digested state.

In these waters the frog was a part of the diet of 
the fish, they took to them with steam enough to show that they wanted to squeeze the choice, dainty morsel between their jaws, but I failed to find the evidence that they were feeding on this tit-bit. Almost all other kinds of feed, such as minnows, crawfish, grasshoppers, dragon flies and such menus I have found, but nary a frog, and I have watched this particularly during the last four years.

\section{WHAT BECOMES OF THE FROG?}

What is the answer? Do the bass strike the frog merely because they want to pick a fight on this little fellow, and why are they so anxious to go for him in some waters, especially in the fall among the weeds, if they do not intend to gobble him down? If there is any angler in the crowd who has a pet theory on the whyfore of this action on the part of the bass shoot in the dope. It will be interesting reading for many of us followers of the call of the water gods.

Which brings us to the old argument as to whether the game fish strikes the bait because of hunger or just simply because he is a fighter by instinct and strikes to eliminate an enemy or intruder in his water. We do know that the bass fights to protect his numerous family during the spawning season and that he strikes a lure at that time as a matter of defense and will often charge it with a swirl along the surface, the top fin cutting the water 
like the fin of a shark. And he will often start at the lure while it is still in the air, judging the distance as he swims and then sometimes even hit the lure before it strikes the surface.

\section{MUSKIE WITH SOME APPETITE}

Just as an example of what the muskellunge will do in the way of striking, when there is absolutely no reason for him doing so in order to appease his hunger, we quote an odd happening upon Long Lake, Wisconsin, three years ago. Ed Dressel of Chicago had an experience with a thirty-pound muskie that shows this game fish up as a scrapper for the pure enjoyment of fighting.

Ed had a cast out toward a weed bed and close along the edge, the bait being a red ibis bass fly with a small spinner. The big fellow lying close under the edge of the weeds, darted out, struck the fly a crashing blow and started off to his lair, only to be snubbed in the effort by Dressel striking him short and sudden. After a fight of thirty minutes the muskie was gaffed and carried up on the shore to show Ed's prowess with the light bamboo rod against the fighting rush of the big chief of the waters.

Up to now there was no reason to think the muskie peculiar in his smashing strike to get away with the fly, but while looking the fish over a pair of waterfowl legs were found to be protruding from 
the throat of the muskie, and with little effort a full-grown mud hen was pulled out, much to the astonishment of $\mathrm{Ed}$ and his pal.

Later, when this same old ruffian was sent to the taxidermist to be stuffed and mounted, the taxidermist found another mud hen in its stomach and six small pan fish and a fair-sized wall-eye pike. The condition of the food showed that it had been swallowed the same day Dressel caught the muskie. 


\section{GIVE YOUR BAIT A CHANCE}

Some days the game fish are actually off their feed and no matter what you do you cannot seem to make them come through with the strike. It may be that at the particular time you are trying to interest them in all manner and styles of lures, casting into the

- shore shallows and working the surface, the fish are down below in the deeper holes lying around digesting with a well-filled stomach, or they may just simply be off the stuff for a while. Anyway, at these times we cannot get them and we pass the buck on the reason of their neglect.

Taking this as the natural cause for the slim stringer at times, the angler should make it a point to develop his skill along the lines that would naturally make his handling the fish better so that he does not play the game to keep his percentage below par. When fishing a stretch of water, the angler who gets the fish is the one who keeps his bait in the water and keeps it moving. The habit now is to carry a well-stuffed tackle box and after, say a dozen casts or so, if you do not happen to raise a strike, to pull in the plug, bait or spinner and hold a little session of about ten minutes, changing to another lure. 


\section{CUT OUT LOST MOTION}

More good fishing time can be lost on the water by keeping up the game of changing plugs than through any other cause and it is also a fact that a fellow does not really give any one lure an opportunity to show what it can do by a few casts and then on to another one. I have many times, while fishing with a beginner, caught quite a nifty string of fish by using one single old battered plug while he was washing a whole tackle box full by giving them a few dashes through the water.

Any old plug will catch fish if you cast it consistently and keep it going in the water. When you strike a piece of water, note the conditions. The water may be particularly clear and the sun out, which would call for a darker plug than the all white, say a rainbow, perch, natural scale finish, green-backed or any of the darker lures, as the all white would make too much of a flash and in a way scare the fish rather than attract them. For the darker, cloudy day, the all white with a red head would be the best choice. Therefore, after having selected our lure, according to what we find as to water and weather conditions, let us decide to give this lure a chance, and ourselves one at the same time, by casting this plug throughout the entire day. It is an easy winning bet that we get more strikes this day than on a day when we lose half our time 
by hooking and unhooking different baits, plugs and lures.

\section{OLD BATTERED PLUG MAKES GOOD}

The dope is that we are fishing most of the time and our bait is in the water where it will do the most good. When we figure that we get a strike on an average of every forty casts it is easy to deduct that we must keep right on casting. And it will be delightfully interesting to know that the battered plug, which we thought was not much for attracting the fish, really shines out as a big winner, simply because we gave it half a chance to get them.

Some years ago while on a fishing trip in northern Wisconsin with an old-time fisherman - in fact, on one of my first trips to the home of the game fish I spent about half the time changing to a new lure and the rest of the time cussing out the last one I had used, getting in a cast every now and then when not busy switching baits. The old water scout stood the game for about an hour and then asked me whether I was fishing for flying fish, I kept my bait out of the water so much, and if so, I had better hit the trail for Florida, the home of those birdies.

Then he shot me the right dope; to fish consitently with one bait until I had at least given the fish a chance to see it, going on to explain that there was not a fish lying in every spot at which I had cast, but it was up to me to keep casting into places 
where I thought a fish might be, until I landed it where one did actually see it.

\section{KEEP RIGHT ON CASTING}

Many times I have watched this same game myself and it seems to be an uncontrolled desire to change baits more than to cast. Selecting a plug from a well-filled tackle box is a gambler's chance at best, and you can pick any one of them and get fish. I have cast from one side of the boat, using one style of lure and my partner has cast from the other side with an entirely different kind, and we both caught fair strings of fish. The reason we did was because we kept right on casting, keeping the bait in the water all the time with the exception, of course, of its flight through the air.

Of course, casting into any old water will not get the fish. The study of waters and formations leads us to know where fish are likely to hang around. A powerful lot of time will be saved by looking over the fishing waters before getting down to business. Casting into the shore shallows, when the bass are in the deeper water, is good exercise, but not very productive of fish victims. Early in the season they are close shorewards in the shallows and even in the warmer weather of the midseason we find them there in the very early morning and late evening, because they are after the minnows of those waters. Where the fish feed is naturally the place to catch 
them, and when the heat of midday sends them way down to the cooler waters of the deep holes, we do not waste time casting the shore waters. If we want them at midday, we drop our bait down over the side and let it go to them, and if they are not too lazy, lounging around digesting the feed they grabbed in the very early hours, we get them. 


\section{BAIT-CASTING LINES}

There are three parts of the bait-casting outfit that must be right to make casting a success. They are the rod, reel and line, and of these three important features the reel stands out as the leading factor, with the line coming in strong for place and the rod nosing in for show.

Quite a great deal of the smoothness of the cast depends upon the line and the size of the line either helps or retards the cast, according to the kind and weight of lure you are feeding to the fish family.

A fellow can trot into a tackle store and merely ask for a bait-casting line and leave it up to the gent behind the counter to pass out his favorite weight and kind of braid that he himself uses, but during the process he does not consider the style of lure a fellow wishes to use, or his rod, as to lightness or weight, that will have the work of throwing out said line.

\section{LINES OF ALL KINDS}

For material used in the makeup of a real baitcasting line there has never been anything discovered that made a better caster than silk, but the mere asking for a silk line leads you right back into 
the muddle again, as this silk affair comes oiled, enameled, soft and hard braided, round or square braided, as well as the line that is braided around a solid silk core.

There are, of course, advocates of all kinds of lines, for the simple reason that a fellow will use a certain style of line and finding it what he thinks O. K., will never really enjoy the pleasures of the other styles because he never takes a chance trying them.

The best all-round bait-casting line, bar none, is the soft, square braided silk line. It casts smoother than the hard-braided line and lies more evenly on the reel spool when reeled in, and there is practically no wear on the thumb when casting the soft-braided affair, while the hard-braided line will sore up a thumb in a day's continuous casting. At the same time one retains better thumb control over the softbraided line, as it does not lower so rapidly on the reel spool during the outgoing cast.

\section{DISADVANTAGES ARE SLIGHT}

About the only thing that can be said against the soft-braided line is that it does not last as long as the hard-braided one, but who of the casting crowd wishes to sacrifice the line that casts best for one that happens to wear a little longer. Also it might be said that the soft line gathers up a trifle more water than the harder one, but this can easily be 
overcome by rubbing the line every now and then with a little oil, which practically makes it waterproof and does not affect either the action or life of the line.

Why the square braided should be chosen in preference to the round braided is often asked. The round-braided line looks better than the square, but it is more closely braided, while the soft braid of the square line has a certain amount of elasticity which makes it stronger under the sudden jerk of the anxious fish to disengage the hook, and this elasticity or pull gives you a little action or " give" when you are holding the game fish fairly taut and your line can stretch enough to, in a way, overcome your rough work in trying to hurry him to net.

\section{SIZES DIFFER ACCORDING TO LURE}

For the lighter lures, such as spinner with pork strip, minnow or frog, or the very small midget plugs, with the rod that has good whip and action, let the choice be a No. 6 soft square-braided silk line which tests out usually from twelve to fourteen pounds and makes a line of just the weight and texture to help you in making a clean, fine cast with the light lures.

When you use the heavier lures and plugs of the ordinary brass size, the No. 5 soft square-braided silk line will handle the bait better than the lighter line, and especially is this so on the steel rod, which 
is generaily a trifie stiffer than the rods of wood and does better casting with the heavier line. This line tests out at from fifteen to eighteen pounds and is almost strong enough for any fishing.

It is often the case that a fellow will load up with a line that tests out at twenty-five to thirty pounds for ordinary casting and then wonder why he is having such a merry time trying to put the cast over with a lot of effort and a maximum of back-lashes. A heavy line will queer more casting than enough and as a rod will not stand more than a direct pull of five to eight pounds without the tip going by the board, why load up with a line that will hinder, instead of assist, your cast?

If you give the fish a chance to run with a little line when he tries to take it and then sneak it away from him when he tires on the run, a twelve to fifteen pound test will insure more than enough strength to hold your game warrior.

\section{FRICTION CAUSES WEAR}

The main reason a line wears out is due to the friction on the guides in casting or letting the line dry on the reel to mildew and rot. You cannot avoid the friction, but you can take care of a line so that it will give you the greatest value in life and action.

Every evening, after the day's fishing, run the line along between two trees and let the wind dry it, 
but keep it out of the sun while drying. This little attention to a line will add oo per cent to its life, as a few times at drying on the reel will rot a weak spot just where the strain is sure to come when you play the big one, about which you later tell the fellow, but don't show them, as it is still in the water home of its own choosing. 


\section{ACCURACY IN CASTING}

Many beginners at the bait-casting sport slip into the habit of trying to throw the bait way out into center field every time they swing the short rod. They seem to feel that about the only thing to do is to put steam behind the swing of the rod and let the bait fall where it may. Probably from reading a wonderfully scientific line of dope on the keen sight of the fish they fall into the habit of taking no chances of being seen, give the bait the grand throw and thus cut down their chance of landing a fish to the possible one that simply happens to be near where the bait lands on the surface or along the route back to the boat.

With possibly few exceptions it is rarely ever necessary to make a cast of over fifty feet, and throwing farther ruffles up the water some, scares a few fish and occasionally hooks one. Of course, after you have developed into a fair caster and can place your bait where you want it, you can add a little more distance to your cast, but at the start you are wasting time, although developing a strong right arm when you ought to be landing fish. 


\section{SIGHT OF FISH OVERESTIMATED}

Fish cannot see for long distances through the water. Were you located straight above the game fish and all he had to do to see you was to look straight up through about three to six feet of clear water, we will admit he could get your number very quickly, but when you are fifty feet away and the fish, to see you, must look through fifty feet of water and on a slant, you can easily dope it out that he does not see very far.

It does not take a scientific research to show that the shafts of light and alternating shadows shooting down through the water make somewhat of a blurred effect that could not be clear enough to see through. Then, again, the magnifying power of water, acting as a lens, cuts out any possibility of a clear vision through it.

Sitting in a boat which lies close to the surface calls for nothing more than fifty feet on the cast. If you are casting from the shore on a bank that is a little higher than the water, you are, of course, more in line of vision, and here either a longer cast or one from the concealment of bushes is more effective.

When you set your speed at from forty to fifty feet on the cast you develop a swing that will usually land your bait at that distance, and continuous casting at about the same distance develops your 
ability to place the bait with accuracy in the weed pocket, along the snag or sunken log where you know a big bass, muskellunge or pike ought to be right at home.

\section{ACCURACY MOST IMPORTANT}

The most important part of bait casting is accuracy, which means being able to place the bait where it will do the most good in the least possible number of casts. You can spoil a lot of good casting water and scare a lot of finicky game fish by thrashing the bait all around the real spot where the game fish lies. Placing the bait in the right spot is not a bunch of luck, but merely practice, and although you can pick up the casting action very easily with an antiback lash reel, you simply have to practice to get the hang of dropping the bait in the likely looking places.

The distance caster does not have the control over his bait that the short caster does, and he cannot keep it under his eye from the drop on the surface until it passes out of the danger zone and is ready for the next throw. Casting within the 5o-foot radius gives you complete control of the bait. You can watch it and often on the strike of the game fish be able to set the hook swiftly by your own strike before it is too late, as the game fish waste no time holding a lure when they find out that it is a base deception made up of gayly painted cedar. 


\section{KEEP YOUR EYE ON BAIT}

Keeping your eye on the bait is as important as any other part of bait casting, and when you throw it way over to the other side of the lake you never see it until half an hour later when it is part way back for the next cast.

Last season I sat through a regular three-act comedy while fishing with a beginner who could not keep down his strong arm. About every fifth cast we had to row into shore and loosen his plug from the bushes and two or three times he tossed it way up into a jack pine. In one hour his string amounted to three pine cones, six frightened pine squirrels that got away, eighteen snags and one bass that happened to be lying close in shore and struck his plug as it flopped off the shore into the water.

\section{SHORT CAST FOR LIVE BAIT}

In casting the live bait with the uplift cast, where you wish to keep the bait alive as long as possible, reeling it in slowly and letting it swim around a trifle "on its own," if it happens to be a minnow, a cast of 30 feet is plenty. And the cast is made with an easy lifting movement, up from the side and out in front of you. This cast is made easy and slower than the overhead cast of the ordinary bait casting with the artificials, in order that your bait will land on the water as lightly as possible. 
I never cast the live bait, however, as it seems just asking the little fellows too much to toss them out in the water until the life is beaten out of them and expect them to attract fish while you are slowly killing them. It is far more humane to kill them before hooking, as they will get just as many fish if kept moving in the water.

To really become an expert at bait-casting, being able to put your bait in the proper place and keeping complete control of it at all times, you simply must give accuracy the first place in the game and slow up on the distance. 


\section{THE REEL AND BACKLASHES}

The rod, of course, is important in the bait-casting sport, but of far more importance for successful casting is the reel.

A reel that does not act right is simply an invitation for a jumbled-up mass of line on the spool, which makes a fisherman swear, perspire and want to fight, as he untangles that dear old backlash, for that is the name of this tangled mass of line. A backlash will visit one more often with a reel that is not acting right than with one which is running smoothly and true.

To escape this jinx of the bait caster, much time and effort has been put in to devise a reel that is not only backlash but also fool-proof, the latter effort being for the angler who must take everything apart just to see what makes it go, some fellows being constituted thusly, and then never getting it back together again with the same fine adjustment the maker had put into it.

There are lots of reels that are just as finely adjusted as a good watch, and the fellow with a nervous hand and a screw driver can throw them out of 
kilter quicker than with any kind of usage on the water.

\section{CAUSES OF BACKLASH}

Outside of any faulty construction of the reel, the backlash is caused by two reasons, either the thumbing of the outgoing line was done improperly, or the line, in being reeled in, has been unevenly guided upon the spool. Of the two faults, I believe that more of the backlashes are caused by reeling in the line and laying it unevenly than through thumbing, although many writers on angling have blamed the thumbing as the real backlash producer.

If you allow the line to pile up at one end of the spool and run up on the end flange, or hump up in the middle, it is bound to fall over and envelop a later wind of line around the spool spindle. This causes a sort of knot or drag, and when the reel is spinning out the line on the next cast no amount of clever thumbing can stop the reel spool from slowing up the instant it comes to this layover of line, and the jumbling mass of line is the natural result.

On the other hand, if you have been careful in guiding the line on the spool over and across and back again, then, as the line carries out evenly on the cast, as long as you simply let the thumb pressure bear on the outgoing line on the whirling spool and quickly snap it down hard as soon as your lure gets out where you wish it to land on the water, you 
will have very few backlashes with an ordinary bait casting reel.

REEL MUST WORK FAST

The bait casting reel is commonly called a quadruple multiplier; that is, the reel spool makes four revolutions while the handle of the reel makes one. This is necessary because the line must run out quite rapidly on the cast and the reel must be geared to bring the line back again quickly for the next cast and with the least number of turns of the reel handle.

There is the rub. Most fellows speed up the reeling in of the line and fall down on guiding it evenly on the spool, probably for the reason that after a little casting the fingers get somewhat tired of guiding the line. At best it is a very trying proposition and one at which a fellow may easily slip up on for this very reason.

\section{THE LEVEL-WINDER}

To eliminate some of this tired finger stuff many things have been doped out and much midnight oil has been burned to relieve the great army of bait casters. Some of these new thoughts have been of value, others merely a makeshift, which, when they were applied to much practical use on the waters, merely caused more trouble than the old original reel.

The level winding reel, however, with the level 
winding arrangement built into the reel end plates and made a part of the solid foundation of the reel, is a mighty good tool and it is not only an eliminator of line guiding, but it also helps lower the caster's percentage of backlashes.

This level winding arrangement has a double wire line carrier that works back and forth in front of the spool and the line runs between the wires of this carrier, the carrier itself working along a worm screw which is turned by a gear from the reel spool shaft.

Many fishermen are of the opinion that this carrier retards the cast, but such is not the case. The carrier moves along with each turn of the reel handle as the line is reeled in. It likewise moves along across the worm screw with the line as it passes out, therefore following the line as it is cast out, there is no reason for a retard to the cast. It simply acts the same as though the line were passing out through one more guide on the rod.

Even should it retard the cast a trifle this would not spoil a fisherman's casting, because, as a general thing, most beginners try to cast too far anyway. Going strong after distance with the cast is the wrong dope; a cast of 50 feet is plenty for any fishing, and made far enough away to strike so that he never even knows you are near. A little more effort for accuracy in placing your bait is far better than going for a lot of distance. 
Of course a reel of this kind, doing so much more than the reels of the old school, must have care and attention. It must be kept clean and free of sand and dirt, especially the worm screw along which the line carrier rides. A drop of oil each day in the oil cups and a drop or two along the work screw will keep it moving lively and with free action. 


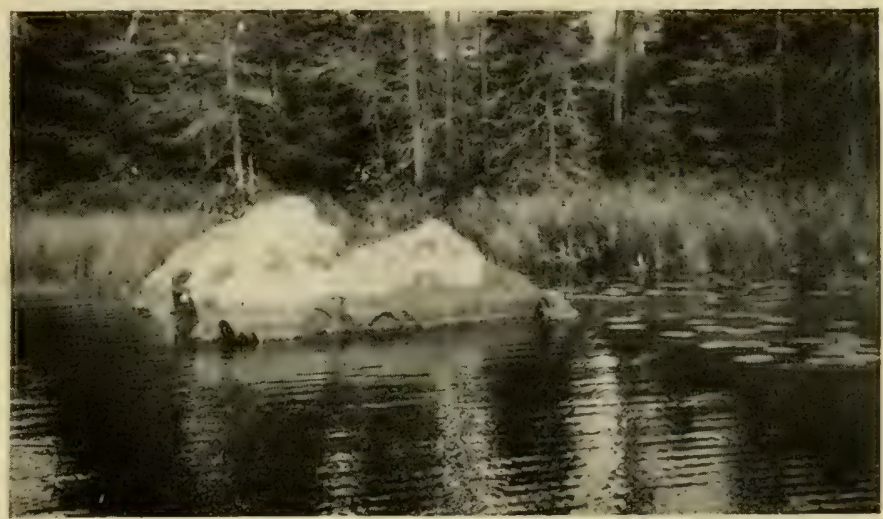

The rocky home of the bass which is often overlooked by the angler. From his home among the lily pads off the right hand edge of this rock a four-and-a-half-pound bass struck on the second cast, while his buddy - a three-pounder - was landed on a cast close in to the left hand edge.

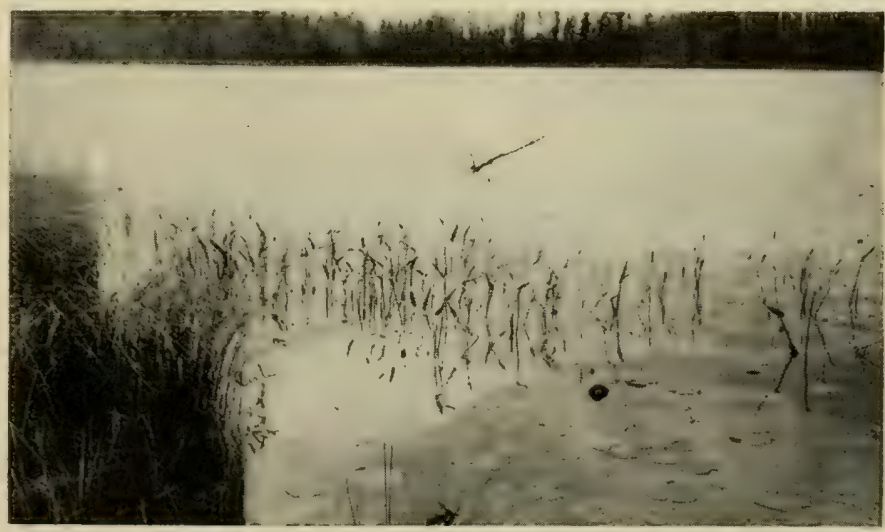

See the little inoffensive snag sticking up in the center of the picture? Many fellows fail to land a cast close in to snags of this kind. After casting the rushes and lily pads in the foreground, we landed a nice bass by placing a lure alongside this little old snag. Don't overlook them; invariably a bass has a snug harbor there. 



\section{FISHING THE SPOON}

A fellow often wonders when he looks over a display of spoons and spinners of all shapes and sizes just what the game fish think the spoon really is in the way of food. As a matter of fact, it is taken for granted that the game fish do not take the spoon for a special brand of feed, but that the flashing light shafts from the twirling spoon as it darts, glides or revolves through the water attracts the fish. It may be that these flashes of light resemble a minnow or shiner, but I have come to the conclusion that it is merely the moving spoon flashing a fighting challenge to the game fish that makes them strike. The bass strikes by instinct almost anything moving in the waters in which he makes his home, and the pike family, including the musky, pike and pickerel, are savage barbarians that strike anything moving away from them.

The spoon as an attractor, when used with any of the natural baits, has a place in the fishing kit that cannot be taken by any other piece of tackle. Hooked on in front of a minnow it makes the minnow a hundred per cent better as a lure. This also applies to the frog, pork rind or crawfish, not forgetting the angle "woim," which, by the way, is the choicest delicacy to all the fish epicures. 


\section{THE SIZE SPOON TO USE}

About the best all-round size spoon or spinner for bait casting, when used with other baits, is the No. 3, which has a blade an inch long and is fiveeighths of an inch wide. This size is the most effective in casting for bass and wall-eyed pike, and many fellows use it in preference to the larger sizes in casting for musky. There seems to be no set standard in numbering spoons by the different manufacturers, and it is advisable in selecting a spoon for bait casting to get one about the above size regardless of the numerical designation on the spoon.

Either the plain, fluted or pebbled spoon is equally effective and as long as it twirls or revolves it will attract the game fish. The closer you connect your spoon to your bait the better, as this will eliminate lost strikes through the fish striking the spoon and missing the hook.

For ordinary bait casting with the spoon you will save many fish by using a spoon rigged with two hooks; that is, one hook close up to the spoon and the other one snelled on to the first hook and trailing about two inches behind. Hook your bait, whether minnow, frog or pork rind, on the top hook and either let the tail hook ride along behind or hook it lightly through the lower end of the bait. With the minnow you can slip the first hook through the minnow's lips and run the other one through 
the mouth out the gills and then hook it down toward the tail. In bait casting with the minnow and spoon a dead minnow will get just as many fish as a live one if you keep it moving in the water, and at that a minnow lives but a short time after being slammed down on the water for a few casts. As a matter of fact, unless I am still fishing or live bait casting with a gentle, short, up-lift cast, I always kill the minnow before casting. Why knock the poor little cusses around and torture them when you can slip them the "hemlock" before casting and get just as good results?

\section{SPOONS OF ALL METALS}

The spoon comes in all kinds of material, copper, nickel, brass, gold, silver, pearl or enamel. For the bright sunny days, when the water is clear and fine, the copper spoon is a winner, while the brass or nickeled spoons bring home the fish on the cloudy day or when the water is broken or slightly rough. For dark waters the Skinner white enameled spoon is a sure killer and it is equally good for deep work and on days that are cloudy. It is not good practice to keep the spoons too brightly polished, as too much flash has a tendency to scare the fish a little. I usually give the spoon a rub now and then when using it just to brighten it, but to give it a hard rubbing with metal polish may spoil your fishing trip.

For a rattling good spoon for all-round casting 
a Lowe-Star spoon with a gold and silver convex side and a red enameled concave stands out as a great fish attractor for most any kind of water or condition of weather. Probably the game fish, like a human, takes a decided fancy for gold and silver, and through his cupidity comes to grief on the stringer, and eventually lands in the frying pan to help save food and win the war.

\section{FOR EVENING FISHING}

For late evening fishing and after dark, I have found a Pflueger Luminous Tandem-Spinner a bait that makes the big ones come across with a strike. This spinner is coated with a luminous enamel that must be exposed to the daylight or an artificial light about half an hour. When used at night it glows like the dampened head of a parlor match. Casting this bait with no other helper in the shape of natural food or trolling it along close up to the weed banks makes a killing lure. The fellow who takes a chance at the late evening and after dark fishing usually is well repaid, as that is the time the big ones are feeding strong.

The larger sized spoons are needed for general trolling for the pike, musky or pickerel, but at that you can easily overdo the game by getting the lures too large. A spoon with a blade two and half inches long and about an inch and a quarter wide is plenty big enough, and the most successful troller. 


\section{THE CRAWFISH AS BAIT}

There are times when one does not seem able to interest the bass in any of the artificial baits; you may try everything in a well-filled tackle box and still the bass don't come through with the expected strike. They will even turn tail to a live wiggling worm at times, and when they do that you can figure it out that they have a particular desire for some one kind of feed that you have not offered them.

The answer is, give them a chance at a half-grown crawfish, that retreating fellow often called a crab by the kids. When a bass has a hankering for the white meat of the crawfish he is going to snoot around until he satisfies that craving, no matter what other choice foods pass his way. For stream fishing in the deeper pools the crawfish shines as an AI bass attracter and during the days of September and October he is a hunted creature. Then the bass are on the still hunt for these tasty bits and you can help fill your stringer with real life-sized fish by playing the crawfish straight across the board.

\section{WHERE THE CRAWFISH ARE}

The crab itself is a sort of a cannibal and each one bores out a home of his own under a rock or root and works that immediate territory. The roving 
crawfish that happens to pass too close to one of these home holes is likely to be crushed between the sharp pincers of the local resident. For this reason in the larger streams the crawfish are not thick in any one spot and the best place to go after them is in the smaller creeks and streamlets that run into the larger bassing rivers. Here the confines of the waters make it necessary for the crawfish to live in somewhat closer quarters, and it is not such a hard job to get a pailful for bait. The best place to locate them is generally in the shallower pools and below the riffles among the rocks and sandy shores.

The crawfish is a quick mover and he has quite a habit of backing out from under your hand just when you think you have him. Slip along the edge of the pools and slowly turn over the stones in the water. The crawfish will be found with his tail curled up ready for a darting retreat. Do not make the mistake of trying to reach straight down for the little fellow, as he is sure to start backward just as soon as he sees your big hand coming down to capture him.

Instead reach a little behind him and he will invariably dart back into your receiving mitt. By working a couple of pools you should have enough bait for the day's fishing in short order and that is enough, as the crawfish is a hard bait to keep alive in a can or bait bucket. 


\section{SMALL ONES BEST BAIT}

The largest crawfish do not make the best bait, as they have a very hard shell and only the larger bass will take a chance on the old members of the family. The smaller or medium crawfish with the soft shell make a far better bait.

Of course if you are going to fish a pool where you know a few real big bass hang out then it is worth while to bait up with one of the harder-shelled old crawfish. For all round fishing the smaller fellows will attract more bass and the real small ones make a rather fine bait for croppies, sunfish, rock bass and perch.

Keep the smaller crawfish in a separate pail from the larger ones for their own protection, as the larger hard shells have a habit of nipping the other smaller members of the family and reducing your bait to a bunch of dead crawfish, which are not of any value as a bass lure. They leave the dead crawfish alone and it is useless to bait up with it.

Also keep them out of the bucket with other live bait such as small frogs and minnows, as they will kill these bait off in short order. To make them happy and contented while waiting their turn on the hook, put a few good-sized bunches of water weeds in the pail for them to mull around. Have the pail half full of water which is plenty, as they will not be jolted so much on the carry. 


\section{BAIT MUST BE LIVELY}

As the crawfish is primarily a still fishing bait for the deep pools, he must be a live bait to be effective, and hooking him through the body does not tend to keep him in a lively humor. A mighty good way to put them on the hook and give them half a chance to move around and interest the bass is to tie them on.

Place the crawfish along the shank of the hook with his tail toward the eye, then take a short length of black thread and wrap it around the body of the crawfish and the shank of the hook. Tied on in this manner, the crawfish has a chance to back around in the water and at the same time the point of the hook is in the direction where it will do the most good at the right time.

The bass strikes the crawfish with a whack and makes a short run, then stopping and crushing the toothsome morsel between his jaws, after which he proceeds to swallow the food. Do not strike before he has time to make the run, and an extra five seconds after he stops gives him plenty of time to put the squeeze to your bait.

Then strike with a will and you have a regular scrap on your hands to land the old past master of the deep pool snags and refuges. The bass does not fool around in a playful way with the crawfish, 
as he often does with the live minnow or frog, but he gets right down to business and eats.

When fishing with the crawfish, keep the bait moving in the water and about eight inches from the bottom. If you merely drop it down and then forget it, the crawfish will likely crawl under a stone or among the stony crevices and cease to be a bait. 


\section{THE SURFACE STRIKE}

There is no part of the entire sport of fishing that gives one more pleasure and enjoyment than the surface strike of the bass or trout. Often in the early season the bait caster using the floating plug will get a thrilling bit of sport out of the bass that comes swirling up to strike the artificial as it rides on the surface or glides a few inches under the water.

This is the real joy time of the bait caster with the bass, as he does not find any of those tantalizing weeds flirting with the bait. The waters are clean and clear and the bass comes willingly to the surface to give battle to the plug of white or many hues.

And well will you remember the surface strike, with the top fin of the bass cutting the water in the dash at the plug. Of the most interesting incident that I recall of many trips to many waters is an experience one June in northern Wisconsin in the famous Eagle River waters, when the bass were coming to the top, not in quest of feed, but looking for a fight.

I had poor luck in locating the fish, being on a strange lake, and up to late in the afternoon had nothing much in the way of fish to brag about. In 
fact, I had kept only one as being worth while in size.

\section{SOME REAL FISHING}

Just as the sun dipped below the ridge west of the lake I ran into a close-bay. Its rocks broke the surface in nice patches and the shore line being full of smaller boulders, everything looked like the home of the small-mouth family. Dropping the anchor, I decided to work all shores and the rocky refuges from the middle of the bay.

The first cast brought a smashing strike right on top of the water. I was fishing with a PfluegerSurprise minnow, white with a dash of red, and it seemed as though the bass could not get enough of it. The plug glided along the surface with a half darting movement of a minnow.

At times the bass would start for the plug before it hit the water, cutting quite a wake with their fins as they rode the surface to the point where the plug was headed. In an hour I had the limit, fifteen nice bass, every one a surface scrapper and every fight a snappy good one.

This leads us to the point that the fly fisherman does not get all of the surface strikes, although he does get them most of the time. The exceptions, of course, are early in the trouting season when the trout are bottom feeding and do not come up for the floating feed which is not yet on the surface. 
This surface strike is the thing that makes fly casting the great sport that it is.

Trout and bass naturally lie low in the water, down near the bottom, if the water happens to be shallow, or better than half way down in the deeper waters. The location of the eyes of the fish toward the top of the head is nature's method of helping them see what feed may be floating along the surface. For that reason it is far more productive of the strike to keep your lure or bait above the fish, than dragging along the bottom, unless of course you are fishing for carp, bullheads or suckers.

\section{SURFACE FEEDING AFTER A RAIN}

The fish feed from the surface, when nature provides the menu at that point. At other times they scout around after minnows and crawfish, although the wall-eye, which is always a bottom feeder, and other fish that prefer the bottom feeding, are not much for taking the top of the water feed. Around about July when the butterflies and stream insects are on the wing, surface fishing with the fly is fine sport. Naturally fly fishing along the streams is better than on the lakes, as conditions for fly casting on the lakes must be just about right to get a good stringer full.' Late in the evening is about the best time to get them up above with the fly on the lakes, but the real ideal times when you can figure on interesting them on lake waters is after a rain, 
or while the tail-end of a shower is still falling. The reason for this is that the rain beats down on the water many of the little winged fliers that ven- ture too far out, and these dainties of the fish diet are eagerly snapped up by the waiting fish.

I have found that following along the shore, either wading or letting the boat or canoe drift, and casting in the waters on to which the flying insects are beaten by the rain, either from the shore line trees or the air, makes good fly casting on the lakes.

\section{FLOATING BASS BUG ON STREAMS}

On the stream one can find much sport by using the floating bass bug which has become so popular during the last few seasons.

The floating bass bug is entirely a surface lure, being a cork-bodied fly that is sometimes decorated in colors or "a la natural" and topped off with wings and tail of hair, or hair and feathers combined. This bug is very easy to handle on the fly rod and can be cast with very little practice. The natural floating action of the bug, together with the wiggle of the streaming wings and tail, makes an enticing piece of passing food that the bass simply must come up to.

I have not found the floating bass bug as effective on the lakes as on the running stream. But it is effective on the lakes when the surface is broken by 
a little movement of the water. This is especially true at times when the bass are rising to surface feed, as the movement of the water in small waves gives the bug a lifelike motion. 


\section{THE MINNOW AS BAIT}

The minnow is the main food of all the game fish, therefore it stands to reason that, as a bait to capture these wise ones, it should come out right up front as the popular natural bait, and it does. The bass dotes on the minnow tribe, of which there are over a hundred and thirty distinct species, some of silver and some of golden hue, with the dark deep golden striped mud minnow leading the whole pack as the livest bait of the crowd.

You can use the minnow as a casting bait, that is the far-flung cast of say 50 feet; as a live bait for casting with the uplift side cast of from 20 to 30 feet; as a troll or in still fishing you can let it work down into the pools and swim around to interest the low-lying bass with its merry wriggle. Of course, to interest any fish the minnow must have motion, life, action. A bass, or in fact any game fish, never strike a dead minnow that has no movement or semblance of life. This does not mean that the minnow must be alive to be attractive as a bait, but it must be moving to make them strike.

To be a little more concrete, let us take the manner of handling the minnow in the different styles of 
fishing it, in order to fool the game fish into thinking there is no string to the feed he drops his eyes upon and is about to snap up with a driving strike.

\section{AS A STILL FISHING BAIT}

The minnow was originally a still fishing bait and at that style he has certainly tacked up a wonderful record as a stringer filler. In the pools the minnow is an ideal still fishing lure and especially during the hot weather can be counted on to work a strike out of the bass as they lie around the bottom in the cool water. In fishing the minnow as a still fishing bait it must be lively. It must swim around and attract the fish, therefore care must be taken in hooking it so that it can perform this function down below, as success in still fishing the minnow depends a great deal upon what your minnow does "on his own" down there in the bass country.

There are two ways of hooking the minnow in still fishing, either through the lips or through the back. The latter method is the most successful, as the minnow has more movements when hooked that way. It is in a more natural position in the water to swim around, while hooked through the lips has a tendency to pull its head down and make the swimming effort unnatural. The weight of the hook pulls down the minnow's head. However, in hooking the bait through the back care should be taken not to strike the backbone in passing the hook 
through the body, as this quickly kills your bait. Slip the hook through the back either above or below the backbone and right behind the top fin. Toss the minnow over into the water lightly and let it work slowly down to where the fish are. Then depend upon the minnow to do its own moving. Every now and then you can give the bait a little movement by slowly raising and lowering the rod slightly to keep it awake.

\section{USE AS LIVE BAIT}

In using the minnow as a live casting bait with the old-time short cast - that uplift side cast, with which Doctor Henshall made his big success - it is well to hook the minnow up through the lips. You make your short cast, say 20 to 30 feet, then slowly reel in the minnow. Slow up to a stop every once in a while and let the minnow swim around a spell. Then reel in slowly and if some old fighting warrior has by chance failed to see your live little coaxer, repeat the cast. This method has brought many big ones to net and although it may not be as speedy in action as the later style of bait casting, it certainly does interest the game fish and get them striking.

For the modern method of bait casting, the long throw of somewhere around 50 feet, a dead minnow is just as good as a live one for bait, as the entire success of this system depends upon placing the bait 
near the weed pocket, $\log$, boulder or whatever likely looking bass home you are casting at, and the keeping of the bait moving in the water. Few, if any minnows have strength enough to live through more than five or six casts. What with being thrown through the air, landing on the hard surface of the water with an awful punch and then being dragged back half drowned, a fellow cannot blame a minnow for throwing up the sponge and passing on to the happy swimming waters of his ancestors. As the dead minnow if kept moving in the water is a good bait, why not kill your minnow first, instead of beating its life out on the surface?

\section{HOW TO HOOK THE MINNOW}

In hooking it for this style of casting, slip the hook in through the mouth, out the gills and then hook the barb in through the body back between the top fin and the tail. In this way your bait will ride naturally when reeled in and it will also be hooked firmly and stay on the hook through repeated casts. If hooked merely through the lips it will fly off on about the third cast as the minnows' lips are none too strong. But remember in casting a dead minnow that the bait must be kept moving in the water and started back for the next cast the moment it strikes the water.

Another method used in casting is to hook the minnow on a double hook; that is, a main hook with 
a trailing hook behind. When using a casting spoon of this kind slip the first hook up through the lips or head, with the trail hook up through the minnow's body back near the tail. This is also a fine way to hook them for trolling, as few strikes are lost through a short strike when they are hooked in this manner. 


\section{MEET MR. WALL-EYE PIKE}

Of all the bottom-feeding fish the wall-eye pike is without doubt the most popular. Although some of the anglers do not class the wall-eye with the other game fish as a fighter, if you play him right you can get considerable sport out of landing him. His fight is not of the spectacular, snappy, dashing fight of the small-mouth bass, nor does he hop around in the air during the scrap. He is more familiar with the bottom and tries to stay down in the territory with which he has a visiting acquaintance.

The fisherman can be thankful to the wall-eye that he is an accommodating chap in the biting line. He has an enormous appetite; is hungry all the time and willing to feed on your bait any time it is placed within sighting distance.

During the hottest of hot days, when the sun is at its strongest, our old friend, Mister Wall-Eye and the whole Wall-eye family are on the hunt for feed. This accounts for the fact that many of the largest wall-eye pike have been caught during the hot July and August days.

\section{WALL-EYE A BOTTOM FEEDER}

Of course, as he is a bottom feeder, gliding along about a foot above the bottom and often lying closer 
than that, we do not waste any time trying to interest him in the surface baits. His main food is the minnow, but he does not turn up his nose at a crawfish or frog, and a good big gob of " night-crawlers" placed where he can get a chance at them is his right dish.

In the way of artificial minnows the green-backed underwater bait is about the best for him. As he is a steady feeder on schools of minnows that make their home in the smaller bays this is a likely place to take a shot at the hungry old rascal. Pick out a small-sized bay or cove and locate out towards the center within casting distance of the shore shallows and throw your casts around the circle of the bay, allowing your bait to sink and then reel in slowly. Don't take the bait away from the fish and don't make him break his neck to chase after it. He is not an energetic party and would rather wait for the next minnow to come along than hurry after your fast reeled lure.

\section{TRAVELS IN A CROWD}

If you get a strike from a wall-eye, play the same water for awhile, because he travels in schools and generally when you locate one of them you can expect to land a fair string from the same waters until the gang starts off on a hunt for better feeding. In this the wall-eye is an expert; he hustles around all the time looking for more food. It is probably due 
to this greedy instinct that makes them travel in schools as they are no doubt afraid the other ones will locate a choice nest of fat minnows and unless they stick together some wise wall-eye will open up a keg of nails without inviting the bunch to name their poison.

At that the wall-eye is not much of a family fish. $\mathrm{He}$ sticks around early in the season, pairs off with a wife and raises a family of a hundred thousand young wall-eyes, swims around among them for a week or so, then starts out with the fellows and lets his family kick around for themselves. And if they don't kick fairly lively he simply eats them rather than look elsewhere for a feed. The lady of the family is not much more of a home maker; she swims away trying to keep up with the old man in his roving. However, the wall-eye is generally well stocked in the lakes that are best adapted to their culture, the deep, cool lakes with a fair share of gravel bottoms and rocky formations. The entire family do not grow up, but enough of them do escape their hungry ancestors and the other game fish to make good fishing for them.

\section{MINNOW THEIR NATURAL FOOD}

For a natural bait the minnow stands ace high and of the minnow family the mud minnow is the best of the outfit as a wall-eye attracter. Whether it is the brownish golden flash of the mud minnow 
or its wiggling lively swim that interests this game fish is merely a detail for the scientists to dope out, the fact remains that the mud minnow is a winning lure for the wall-eye and he is crazy to feed on them. Used with a small spinner or spoon the minnow is even more attractive than fished alone.

Of course the mud minnow is not the only one that makes good as a wall-eye bait. The chub, shiner, small perch and sucker have an inning and are good. The pork rind with a small spinner is also very effective. Hook the minnow up through the lips or run the hook through the mouth, out the gills and hook it in the back right behind the top fin, but not deep enough to hit the backbone. This latter method is the safest for casting as your bait will stay on the hook longer than by hooking merely through the lips. In still fishing, however, I prefer the lip method, as the minnow is more lively when hooked that way. You need a lively bait fishing in that manner, while in casting the movement of the minnow in reeling in takes the place of the kick necessary in still fishing.

\section{FIGHTING TO STAY BELOW}

Often when a large wall-eye strikes your bait he will simply strike it and make no further movement and you begin to say bad things about another snag, but a fairly heavy pull on your line will wake him up and the series of tugs and pulls he makes will serve 
notice on you that you have hooked up with a big fish. He fights a bulldog scrap of jerky pulls without any long runs. You may bring him up to the boat, but not to net him on the first trip, as he has a habit of fairly burning the line off the reel on a run back to the bottom. 


\section{TO THE MUSKY}

Of all the freshwater game fish that delight the heart of the angler because of their fondness for the flashing, revolving spoon or the succulent natural bait there is none that makes the short hairs on the back of the head stand up like bristles as quickly as the musky. He's a rough customer from the instant of the strike until you have him safely held up for the snapshot of the victor and his victim, that is, of course, if he tips the scales at a high enough figure to make you want a picture of the happy event.

When the musky is on the strike anyone is likely to have a chance at a battle royal with this rough old actor. He cares little whether the lure is handled with the fineness of an expert or just dragged along by a rank amateur. The high art of angling is not at all a necessary part of the training of the fellow who goes after the musky. If he is in the humor to feed or feels like a fight he will strike most anything moving along in the water.

It is interesting to know that he is not a respecter of persons and therefore that any of us have an equal chance at his nibs if we happen to strike his home waters when he is lively and full of pep. Many regular musky fishermen, who have been at the game for years, have still to land their real big one, while 
many beginners at the sport of fighting the big fellow got theirs on the first trip out.

\section{AMATEURS GET LARGE ONES}

-While digging into the past performances of the musky along these lines we find that last season at Lake Vieux Desert, at Donaldson, Wis., sixty-five musky were caught from twenty pounds up to fortytwo. And among the largest were two fortypounders caught by men who had never coaxed the musky before and two thirty-eight-pounders were landed by women on their first try for fame as muskyteers. One of these forty-pounders struck a No. I-o Lowe-Star spoon with force enough to bend it double, which is sure striking some. It takes a mighty attractive lure to make 'em fighting mad.

Many an old hand at the game who has been trying to land a granddaddy of the outfit would have done everything but commit murder to have had the rod in his hands when these gay dogs struck.

The best time for musky fishing is generally early and late in the season, with a trifle of a slow-up in the hot weather, although he may surprise you at any time and be on the feed when you least expect it. However, during the "dog-days" of August his teeth and gums are in poor shape and he needs a dentist more than a feed, at least he is not very much interested in what you show him in the style of baits, spoons or lures. 
FOND OF SUN BATHS

Ofter in the hot weather of late July and August you will find the musky lying close to the surface taking a sun bath, stretched out to his full length, a few inches under water, merely moving a fin or so. You can toss everything in the tackle box toward him and he never bats an eye and at a time like this it's an easy bet that you will get more fish if you make it a little still fishing for the wall-eye or hunt up a spring hole for bass.

But, a tip for a little evening fishing, after the sun has passed over the horizon and he is more than likely to be on the feed, may bring you a fair-sized member of the tribe.

About the best day for musky fishing is when there is a little riffle to the surface, not too rough, but enough movement to liven up the water and keep the musky on the move for feed, and an overcast or cloudy day is likely to be more productive of a strike than when the sun glares down on a glassy surface.

\section{MAKE THE GUIDE USEFUL}

To fish for musky in strange waters without a knowledge of the underwater weed beds, the rocky ledges and formations, takes up a lot of valuable time that could be devoted to fishing. And to try the game with only one man in the boat is bad business. It is hard enough work to keep the musky 
from mixing things up in among the weeds or snags when you have the help of some one at the oars to hold the boat right and work out into deep clear water, to say nothing of gaffing him if you were lucky enough to keep him on the line that long. Take a guide along for a few days until you are somewhat familiar with the waters. Afterward you can split tricks at the oars with a pal for the rest of the time.

The musky is touted as a top of the water fighter by most of the boys who talk about him. Like other game fish that break water and do a dance on the surface he fights that way mostly through necessity. The musky hooked in shallow water, say from five to ten feet, is sure to come up into the air because that is the logical thing for him to do. He usually makes a drive for the bottom to loosen up the hook or wind in among the weeds and pull the stinging barb from its mouth.

Finding that this system does no good, he makes for the surface, often breaks clean of the water and gives a powerful shake of the entire body in an effort to throw the spoon or bait. And generally he continues his tactics of bottom rubbing and top of the water shake as long as his strength remains. If hooked in deep water and kept there he fights an underwater battle until worked to the surface.

Many big muskies have fought the entire battle without hitting the air, because they were played in deep water. 


\section{SPOOLING THE LINE}

There are a lot of fellows in the bait casting game who pride themselves particularly on the skill they have acquired at thumbing the reel. And this is an art upon which they have a perfect right to feel their oats, as the saying goes.

To become an expert at casting, the main thing depends upon thumbing the line, that is, if you use the ordinary quadruple-multiplying reel. There is no way to get onto the hang of thumbing except through practice and to become a regular dyed-in-thewool expert, one must devote considerable time to thumbing.

Many of the great crowd of embryo bait casters would get right into this sport if they had the time to devote to practice, but being a trifle limited as to time they feel that sticking to the long cane pole is about their limit and thus they lose the real thrill of angling-casting.

The level-winding reel, in a way, has helped many an angler along to the enjoyment of casting the plug, spinner, pork rind and natural baits, but the real tool of the sport that has made bait casting as simple as $A, B, C$, is the antibacklash reel. With this won- 
der-worker of the reel family most any one can, in say half an hour or so, toss out the bait with as much skill as the fellow who has given much fishing time to learning thumbing, and during the process, become thoroughly well acquainted with the art of unraveling those dear old backlashes.

\section{FISH WHILE LEARNING TO CAST}

Of course, the new-fledged caster who has entered the big family via the antibacklash reel route will not have the accuracy of the expert, but this can be acquired by actual work on the waters and he gets fish at the same time. He can throw just as many casts and with less trouble than the regular caster who uses the ordinary quadruple-multiplying reel. For the beginner at the sport there is nothing better, and for the lady who likes to go along there is in the antibacklash reel a tool that will make a good bait caster in short order and great will be the joy thereafter.

Where the antibacklash reel shines, even for the expert caster, is in night or moonlight fishing. Who of us has ever experienced the delights of a backlash at night and come through the battle of trying to juggle a flash-light, a rod and untangle the backlash at one and the same time without losing our temper, cussing a blue streak and swearing by all the water gods never to go out in the dark of the moon again, and there is no time when the bass and other game 
fish are more active and on the feed than at night. This is especially so during the warmer days of summer and many are the big full-grown bass that have answered the last call to the fellow who was live enough to go after them at night when they were in the humor to strike.

\section{REELS THAT DO EVERYTHING}

The early antibacklash reels were designed along the standard shape of the ordinary reel with the long, low spool, a neat appearing well balanced winch, and they reduced the average backlashes to a minimum. But the reel that made casting a joy forever, cut out the backlashes, the tired fingers, due to guiding the line on the spool, and did most everything but "spit on the bait," is a "Pflueger-Supreme" a combination level-winder, antibacklash and free spooler that makes a good caster out of a fellow whether he wants to be one or not.

By a quarter turn backward of the handle the reel is made a free spool, and the line passes out without turning the reel handle at all, the line carrier remaining stationary while the cast is made, and there is no added friction on the line against the carrier to wear down the life of the line.

After the cast is made and on the first turn of the reel handle to retrieve the line the carrier picks up the line and lays it on the spool evenly for the next cast. A good point about this line carrier is 
that it is inclosed, and is therefore sand, dirt and waterproof, and a drop of oil every day keeps this part of the reel running smoothly.

The wormscrew along which the carrier rides does not gum up with dirty grease and sandy grit that cuts into the metal or slows up the reel. As the carrier is merely a slotted block, which does not encircle the line, there is no interference at all on the outgoing part of the cast.

\section{THUMBERS CONTROL CAST}

The antibacklash arrangement is a pair of automatic thumbers on the inside of the spool which bring pressure to bear on the end plate as the tension on the line slows up when the bait ends its flight in the air and settles on the water. As the force of the cast throws the lure out these thumbers do not work against the end plate, but the moment there is no further drag on the line they stop the spool and you are ready to reel in for the next cast or play the strike if you are lucky enough to get it.

On the end plate of this reel there is an adjusting screw by which the pressure of the thumbers can be regulated for different weights of lures, as there naturally would not be the same amount of pull to a light spinner with a strip of pork rind as one would find with the heavier plug or large spoon.

And for the fellow who wants to take a shot at thumbing the spool, although there are few who 


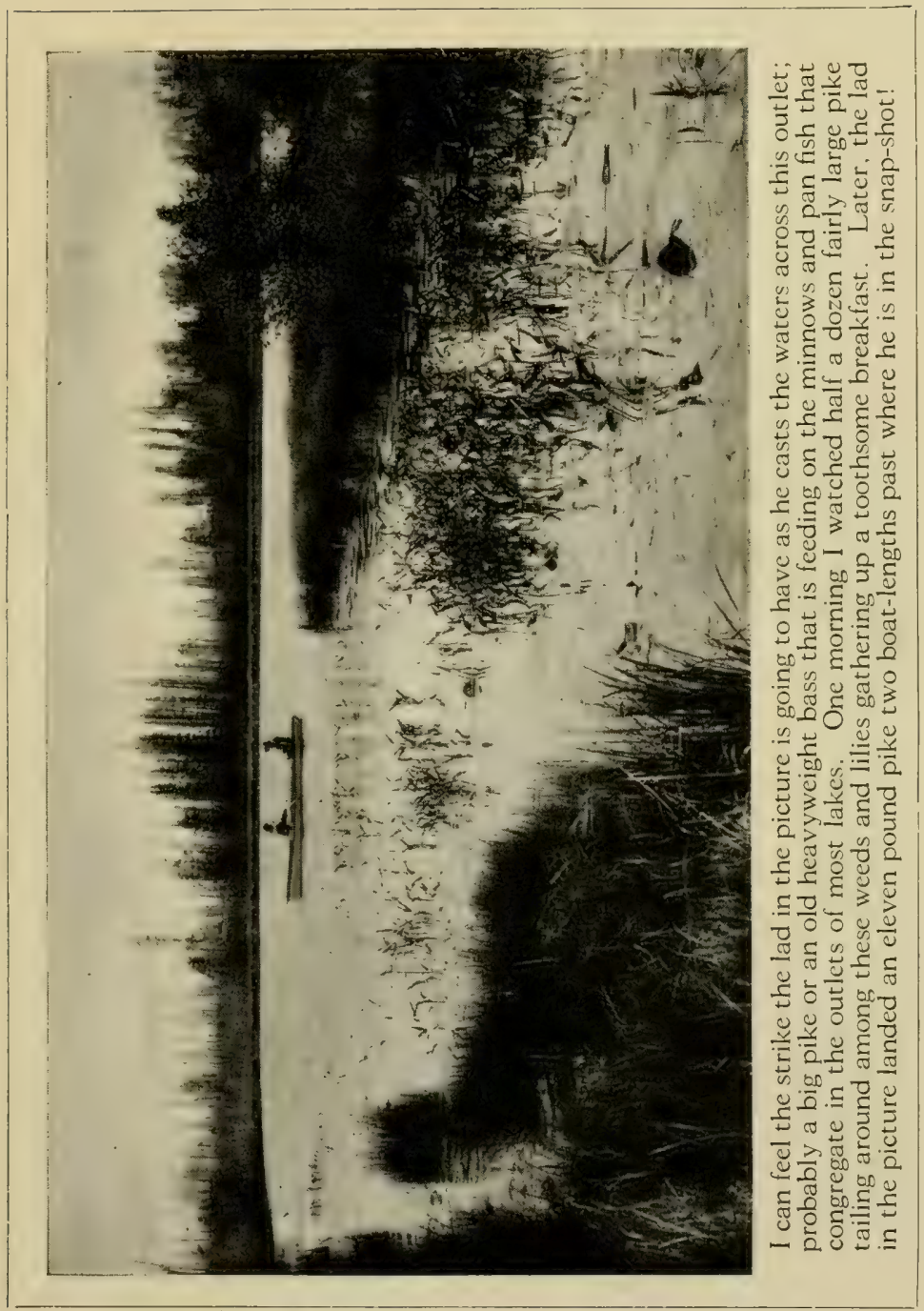



will bother with this end after enjoying the antibacklash reel, the adjusting screw can be given a complete twist and the reel is a level-winding free spooler, the thumbers being out of action entirely.

Naturally a reel of this kind, that does about everything except turn the handle, must be given care and attention. 


\section{THE FROG AS BAIT}

Although throughout the entire fishing season the frog may not shine as a wonderful bait for the pike, musky and pickerel, as the end draws near these game fish develop a wonderful appetite for his hopping lordship, the greenbacked white-bellied frog. From the tail end of August right up to the snows you can give the frog the merry toss and have a very good chance of interesting some of the game ones that are skirmishing around looking for just such a feed.

At this time the frog has developed from the tadpole stage, he has a strong pair of hind legs and he is just feeling the kick in them. Feeding as I he is at this time from the surface close along shore or hopping around among the grasses and reeds gathering in the small grasshoppers and other insects, he is easy bait to secure.

The ordinary frog basket, a small split affair with a cloth top fitted with a draw string opening is a handy way to carry the frogs. Place a little moss or soft weeds in the bottom and your frogs will keep in fine shape all day. Occasionally, to freshen them up a little, it is well to immerse the bottom of 88 
the basket in the water. However, frogs will keep in fine, lively shape without water for the day. During the night you can stand the basket at the edge of the water with one end slightly in or leave it in the water a short time and then stand it on the damp ground in the shade.

There is one method of getting frogs for bait that is interesting and quite a lively proposition. That is the night-time frogging expedition. This requires two fellows, one to handle the oars and the other to capture the hoppers. You back the boat slowly along the shore where you have located frog signs during the day, generally along the marshy shores of the lakes, around the outlet or along the lowlying shores of the stream. The frogger sits in the stern and as you back slowly along flashes a light along the shore where the frogs are sitting, piping their guttural songs of love and war. The light blinds and confuses the frog, and he will not jump for ten or fifteen seconds. Of course, you don't want to overestimate your distance and take a header into the water, but that is one of the things that makes the night frogging trip interesting.

\section{SMALL FROGS ARE BEST}

In selecting your bait, do not make an effort to get the great big frogs. They are not half as interesting as the smaller ones, although a good, large frog makes a fine trolling bait for the large pike 
and musky. The small leopard frogs and the pickerel frogs make about the best bait for the bass family.

The frog is a good casting bait, and when used with a weedless hook and a small spinner, say a No. 3 , or hooked onto a luminous tandem spinner, it can be cast right in among the weeds, which is the spot where you usually find the bass and big pickerel in the fall season. Casting along the edges of the weed-beds does not bring the game fish out at this time as much as throwing the frog right in among the weeds.

Oftentimes the frog will be struck short and the hind legs stripped off. To avoid this loss of bait and fish, and to fool the old fathers of the finny tribe, you should use a trail hook. The frog should be hooked on the top hook and the trail hook extending down along the frog's legs will get these wise fins that steal your bait.

The usual method of hooking the frog for casting is up through the lips. For casting, that is, out and out bait casting, where a cast of 40 or 50 feet is necessary, I kill the frog before hooking it. A dead frog kept moving through the water while casting is as good a bait as a live one, and killing them first is more humane than pounding them to a lingering death on the surface of the water. I am just a trifle too chicken-hearted to watch the almost human efforts of the frog to work the barbed hook 
out of his mouth with his front legs. They seem just like a pair of hands as the frog grasps the shaft of the hook in a vain attempt to get loose. Then again, the frog only stays alive through a few casts, and the effectiveness of your far cast frog depends on your own skill in retrieving it, to keep it moving from the instant it strikes the water.

\section{TIE HIM ON THE HOOK}

By far the most effective way to play the frog, in my opinion, is to tie one on the shaft of the hook, using a short piece of black thread or a small rubber band, passing the thread around the small part of the frog's body and the shaft of the hook, with the barb below the crotch. In this way the frog will be a lively kicking bait and do his part until a big bass spies him and goes home with the feed.

Go right into the weeds with this rig and with a slow uplift cast of the old-time live bait caster, land your frog lightly out among the weeds about 20 feet from the boat. Let the frog settle a little, reel him in slowly for a few feet, let him rest again to kick around that spot, then reel in again for a couple feet, let him nose around some more and repeat the dose slowly.

If there are any bass or pike around your frog will probably not make more than one trip back to the boat before he is gobbled up by a game fish. This method may not be quite as exciting as the 
regular casting, but your time comes when you play and land the fish in the weeds. Your chances of getting the big ones and more of the medium-sized ones are greater, however, than via the other method and you have an excellent opportunity to develop your skill at playing the fish, which will make a better angler of you. 


\section{THE PIKE FAMILY}

Of the entire fish family the pikes can be most relied upon to come forward with a strike and put up a rather interesting fight in the fall. The pike branch, or species, of the finny tribe is composed of the rough-fighting muskellunge, the true pike, sometimes called great northern pike, but usually termed pickerel by the big run of fishermen, and the pickerel himself.

In general shape, contour and characteristics these three pike cousins are about the same, but in color and markings they have a decided dress of their own. Of course, the muskellunge is the scrappiest bird of the family, and he has earned a wonderful reputation as a wise old actor from the many tales of his wily fight when hooked, but the pike, caught in the cold lake waters or in the running stream, puts up a fair fight, although the pickerel does not grow to size enough to really make a rough fight at any time, unless it may be when landed on a long light rod that gives him a chance to do a few stunts with his tail.

While the general shape and contour of the body of these three game fish follows the same lines, the 
muskellunge is the bulkiest of the trio, the pickerel being the slimmest of the outfit. The head is about the same in shape, being a trifle flattened and large in size for the rest of the body, with a mouth that fairly bristles with sharp teeth and a lower jaw that seems to protrude a little forward of the upper one. The fins are the same and they are in the same position on the body.

\section{WATER GOVERNS COLOR}

As with all other game fish, the waters in which they live seem to control the color of the body; this is, waters containing plenty of mineral substance may shade off the colors in one direction, while waters of a certain vegetable makeup will tend to color the fish a decided lighter or darker color.

The basic color of these fish is a dark green on the back and sides, tinting off to a greenish yellow on the stomach. In some waters this body color runs in a brownish green, while the belly may run to a cream or whitish yellow color. In the body color the three fish may be the same, but the spot markings are noticeably entirely different.

The muskellunge's spots or stripes are of black or brown and they run across the body and not lengthwise with it, and these spots or stripes are sometimes irregular vertical daubs. The spots on the pike are round and usually light yellow, often almost white of a yellowish tint, and they appear 
as though daubed on with a small, round paint brush. They are not, of course, perfectly round spots, but more of an oblong smear and they run lengthwise with the body.

The marks on both of these fish seem to be placed on the body color while the markings of the true pickerel are so numerous that they seem to be the body color and the darker tracing of the irregular design surrounding them makes a chain effect from which they have often been called the chain pickerel. These spots are of odd shape and size, being a trifle oblong or oval and no two of them seem to be exactly the same size, the color running to silver gray.

\section{HOW TO JUDGE THE FAMILY}

As we know, the muskellunge runs to big size, having been caught on rod and line up to $6 \mathrm{I}$ pounds, while the pike has been caught up to 29 pounds, but the true pickerel never runs to more than eight pounds, and then in rare cases, the usual size being two to three pounds.

In order to avoid a lot of useless argument as to the correct status of these fish, there is one way of judging them that is absolutely sure, and that is by observing the cheeks and gill covers. On the muskellunge the cheeks and gill covers have a very narrow strip of scales on the top, on the pike the entire cheeks and the upper half of the gill covers 
have scales, while the true pickerel has scales all over the cheeks and gill covers.

As soon as the ice goes out in the spring the entire pike family spawns and starts their family out in their watery world. From that time on they are on the still hunt for feed, slowing up a little in the hot days of July and August, but coming back strong as soon as the waters cool. September is good, but October and right up to the snow days they are right after the luckless minnow, pan fish or frog that happens to come into their line of vision. They are all still, lone hunters, having the characteristics of the barbarian. They lie in wait along the edges of the weedbeds over the tops of the underwater weeds and down among them, snapping up everything that comes their way. None of them travel in schools; they don't want any friends and are vicious strikers.

The spoon hook is the best all-round bait for any of them, and about a No. 6 size makes the best trolling bait. For the muskellunge or pike the large suckers, shiners or minnows hooked onto a I-O LoweStar spoon of gold and silver with red concave is right for either casting or trolling, and the big fish cannot resist its flashing invitation as it twirls through the water. A very good lure is to take a piece of fresh pork and cut it into a strip about the size of a cigar, say six inches long and rounded a trifle like a cigar. Hook this on to the treble hook 
of a spoon, looping on a trail hook that reaches back to the end of the strip.

This is not the ordinary thin pork rind, but it certainly does interest the pike and musky and has size and bulk enough to give them a chance to sink their teeth into it. A little red yarn tied onto the trebled hook with the ends dangling along the pork strip seems to arouse the anger of these villains and make them strike quicker. 


\section{HANDLING THE ROD}

A very important part of fishing, after the strike of the game one, is the handling of the rod in playing the fish. Not only is the spring of the rod necessary in throwing the cast, a thing that makes it unnecessary to use up your strength, but this same spring is the thing that plays the fish to a standstill if you use it right. After you have developed your casting to the point where you can start the cast with the backward swing and then let the momentum thus developed help on the forward sweep, you will find that you are throwing your bait with far less exertion than when you start the cast from the still position of the rod back over the shoulder.

Of course, at the beginning it is well to start the cast with the rod back over the shoulder and the bait dangling down a trifle, say, reaching on a line with the waist. This is the position from which you make the forward sweep and develop your accuracy at the start. However, using the back and front cast gives you the advantage of every bit of action in your rod and also gives you more confidence in your cast, making the wrist and forearm do most of the work and yet doing it with such a small effort 98 
that you can cast all day without becoming tired in the arm and shoulder muscles.

\section{HARD PULL BREAKS ROD}

After the first strike of the game fish you set the hook with a backward jerk of the wrist, at which time usually the fish makes a decided effort to go to the far end of the lake or stream. Right at this point many fellows clamp the thumb down on the reel and the running fish, pulling like a bull pup, puts a strain on the rod that draws it into an arch that almost makes the tip touch the butt.

Right here is where the beginner develops " buck" fever. The arch to his rod sort of makes him wild and he tries to "hoss" the poor old game fish right off his feet and drag him into the boat. Very few rods will stand a strain and pull of this weight and naturally the rod breaks, as there is hardly a rod of either split bamboo or the solid woods that will not break with a dead pull of six or eight pounds.

The thing to do at this moment is to hold the nerves in, keep cool and let the fish take the line for a run, then as he slows down in the run let the rod arch and stop him.

\section{CARELESS HANDLING OFTEN CAUSE}

Naturally there are times when the rod is broken through plain carelessness and inattention on the part of the angler. Just last week I had a pet beth- 
abara rod broken because I failed to keep my mind on the game, which was fishing at the time. Up in northern Wisconsin in Kate Piera Lake, there is an old granddaddy bass that has passed the buck to a number of well-known anglers, and he dished the same stuff up to me last week.

Last season, early in July, this old bass of rare vintage and much weight made a short strike at a frog bait, tossed it ten feet into the air and broke water for a clean arching dive; later the same season, in September, he took Ed Wyman's hair fly, coughed it high in the air before Ed could strike, and stood on his tail for a moment before hitting the water trail for somewhere else.

Last week I was casting the same old bay for this rare one, having heard of his reputation and weight, Wyman setting the figure at nine pounds. With an additional year's growth I had a chance at landing a ten-pounder. I had worked the bay waters four times, and on the fifth time around my fishing partner at the oars called my attention to the broken-down muskeg on the edge of the bordering tamarack swamp where the deer had been eating lily pads the night before.

I had made a cast. My Pflueger-Surprise minnow was reeled to within four feet of the boat as I looked at the scene of the deer banquet, when there came a smashing strike and my rod snapped off at the ferrule as the big bass dashed under the boat, bring- 
ing the rod at right-angles on the edge of the boat.

The line gave with a snap, and the big bass was off for other waters, probably chuckling at his new trick on a visiting angler. I never saw him. The strike and dash came before I could raise the rod, and my pal, who saw the bass as he struck, said he looked like a whale.

\section{KEEP MIND ON THE GAME}

When you are fishin' you got to keep your mind on the game every second. You can't study the tamarack swamps and land the unexpected strike; and, by the way, you never know just how close up to the boat they will strike. Of course, you expect the strike from the bass as the lure hits the water, or within a few seconds of reeling in, but you may get them right at the boat, in which case quick action is the only thing that will save the fish and your tackle.

I am now lined up with the gang who have tried for the big bass and been fooled, while paying close attention to my knitting may have meant that I would now have a record-breaking small-mouth bass to dangle in front of my friends.

While on the same trip I watched a beginner land a seven-pound pike, during which he put his split bamboo rod through a run of paces that made me shiver. After bringing the pike right on top of the water and not losing him then by sheer luck, he 
arched his rod through a number of twisting curves and ended up by working his right hand down along the rod to within a foot of the tip and tried to play the fish to net that way. Only quick work on the part of his guide with the landing net saved the fish and the rod, the latter having a wonderful bunch of twists and kinks in it after the battle. 


\section{HOT WEATHER BASSING}

There is no end of the fishing game that will help fill the stringer more than a thorough knowledge of the habits of the game fish for which you angle, and about of the same importance as this knowledge of what the fish do in their daily kick around the water promenades is a thorough acquaintance with the waters you fish.

The knowledge of the habits is necessary in order to save you a lot of useless casting in places where the game fish do not happen to be at that particular season, time of day or condition of the weather. A familiarity with the waters you fish gives you the right line on underwater formations, weed growths, shallows, sand bars and shoals, as well as other homes of the bass, pike and musky.

After spawning the bass leave the shallows as a permanent home and only come back to them during the warm weather to feed on the minnows that school in these places. Casting for bass along the shore shallows on a hot day, except in the very early morning and the late afternoon, is great exercise for the arm muscles, but not productive of a well-filled stringer. 


\section{PREFERS LATE AFTERNOON FISHING}

I have a decided preference for the late afternoon fishing, keeping at the game right up until dark, and then if it happens that the moon is to be with me I stay around and get a few big ones.

Of course, if I have prepared for a little try at the real night fishing when it is black as the proverbial cat and have selected a cove or bay where I have found the minnows schooling thick during the afternoon, and have located the weed beds, snags and logs in the bay so that I can cast into the waters without snagging on every throw, I stick around and fight it out with some of the old "lunkers" that have a habit of feeding on the real dark nights. Once you have taken a shot at this night work you will be a confirmed night caster. The big ones you bring home will cause your chest to take on an angle of 45 degrees and all the other brothers of the sport will want to know the answer.

At the morning stunt, four o'clock for the first cast is none too early and then the casting is generally good right up until the sun begins to send down burning rays. From four to seven o'clock makes ideal early morning casting and in three hours you should be able to cover quite a stretch of water and bring home the bacon in the shape of some of the fathers of the bass tribe. 


\section{STUDY NEW WATERS}

In the early morning most any waters that you would cast at in quest of the bass makes fine sport with good chances of results, among the rushes, the weedbeds, the lily pads and along the logs, snags, brush heaps as well as off the sand bars and the gravelly shoals. I make it a habit in fishing new waters to put in the midday time trolling along around the lake, spotting the likely looking places, making mental note of the weed formations and the rocky bottoms. In a few days of patroling in this way you can get a fairly good idea of any waters.

It is not at all necessary to give up fishing during the hottest day. After gorging on the fat young minnows in the late evening and having a little frolic on the surface during the night with another good feed in the early morning, the wise bass hunts up a spring hole in the deeper pools and makes himself comfortable for an all-day siesta. Incidentally while lying around he is also digesting his food and doing it with the least exertion.

\section{TRY MINNOWS AND FROGS}

Oftentimes when the water is clear and still you can float along and see the bass way down below; I have often floated along on lakes that I have fished quite frequently and know the waters. I found plenty of bass down deep and have watched them 
for hours, hardly one of them making a movement that is noticeable. If you let a minnow or frog go down slowly aided of course by a dipsey sinker, these same bass will generally take notice when the bait comes within their vision and one of them will grab it and make a short run before stopping to turn the minnow or frog around in order to swallow it head first. After you have safely played this fellow up to the net you can repeat the operation and clean up the whole school. It seems that the bass cannot resist the wiggle of the minnow or kick of the frog even with a distended stomach in the hot weather if you send the bait down to them.

Incidentally the old friendly fishing worm of our childhood angling days is a bait that will make any bass happy on a hot day if you pass it down. After the strike the sport of landing the bass is just as snappy as it would be were he caught through the casting method. Hook the worm lightly, passing the hook through just a nip here and there so that he retains his acrobatic twists, which is the main thing that attracts the bass when invited to feed by the worm.

For the early morning and late afternoon casting most any surface or semi-surface plug is right with a preference to the white with red head and the green back with white belly, although the new natural scale finish has been a killer for the short time it has been out. The pork rind strip with a small 
spinner and a touch of red flannel as a fancy fish food takes a back seat for none. For the night and moonlight work the luminous Pflueger-Globe plug with the spinning head, attached to which is a propeller. This bait makes an excellent lure, kicking up quite a surface riffle as it is reeled in, and at the same time you can see it as well as the anxiously waiting bass. 


\section{AMONG THE CATFISH}

This will introduce the catfish, commonly called bullhead, the homeliest fish that swims around the home waters. He looks worse than the morning after a night out, and he carries a wicked pair of horns that he can use in defense when you try to slip the hook out of his innards. Believe me, he certainly has it well swallowed every time you hook him. The most popular of the whole catfish family is the little fellow, the bullhead, and he is also the most common. It is rare that this specie reaches a length of 18 inches or a weight of four pounds, the average size being under a pound.

The bullhead is at home in nearly all ponds, lakes and streams. He prefers the muddy bottoms and likes to wallow around in the mud and weeds, eating everything that comes in his way, and disposing of a lot of feed that would be better for the real game fish. The warmer the water the better he likes it, and for that reason you often get him when the other fish have left the warmer places for the cool spring holes. $\mathrm{He}$ is a lazy rascal, and although eager at all times to take most any bait offered, he does not speed up in an effort to get your bait unless you drop it down to him. 


\section{FEEDS ALONG THE BOTTOM}

Meandering along on the bottom or a few inches above it, diving down every now and then to root out a little food from the bottom, he makes it necessary for you to fish with your bait about eight inches off the bottom. If he comes anywhere near it he will swallow the bait like a sucker. If the fish is fairly large, as soon as he feels the prick of the hook away he goes for quite a run and at fairly good speed, ending up with a series of pulls and tugs that would do credit to pike-perch, better known as the wall-eye, who is a past master at that little game.

A dainty in the bait line for his nibs is the lowly angle worm, and he certainly loves the juicy worm. Hook them on so they may wriggle a little and be more attractive to the bullhead. A good method is to slip the hook through about a third of the way down the length of the worm, then skip a third from the tail end and slip the hook through again. In this way the worm is free to curl and turn in an enticing way around the shaft of the hook and make an inviting-looking feed for a voracious flatmouthed bullhead.

\section{APPETITE EASILY SATISFIED}

The worm is not the only bait, however. The soft-shelled crab, a piece of ordinary beef liver, a mussel, a small strip of raw beef are good. What 
has been found most excellent, in the streams in the holes around piers and bridge abutments, is chicken liver. This latter bait should be hardened by rolling in a little sugar about 24 hours before you intend to use it.

In fishing for the bullhead the most ordinary tackle is just as effective as anything; say a long cane pole of about I 4 feet with a stretch of linen line about the same length as the pole. On the end of the line it is well to use a three-foot gut leader. The hooks should be large rather than the smaller sizes. He takes a large hook just as eagerly as a small one if baited, and as the hook is always swallowed and caught well down in his tummy or throat, you will find it far easier to disgorge the larger hook than the little one. Best way to disgorge the hook is to split the fish along the tummy to the gills and make the grip strong behind the head so he does not slash you with the sharp old horns. One wriggle of the head and he gives you a punch that will develop into a lovely sore in a day or so.

\section{TWO HOOKS ON THE LEADER}

Two hooks on the line are very effective, one tied on the end of the leader and baited with raw meat and the other one up about six inches baited with the wriggling worm. If the bullhead overlooks the meat he is almost certain to see the worm. Use a float if you like to lounge on the bank or in the boat 
and when it begins to bob just raise the inquisitive rascal into the boat and go after another one. When they start biting you can figure on a good string, as they are generally as thick as fleas on a cur dog.

The main reason for using the gut leader is that it makes the line stand up in the water, and you can judge the distance to the bottom better than with the line alone. Slip a couple of split buckshot sinkers or dipsey sinker on the leader to take the bait down.

Of course, you can get more sport out of the bullhead game if you use a long whippy steel fishing rod and a reel. In fact, quite a little real fun can be coaxed out of the bullheads this way if none of the game fish are around.

The nearest thing to a game fish in the cat family is the channel or spotted cat. This member of the family is the real sport of the outfit, and in color runs from a dark gray or slate color on the back to a white tummy, and is dotted with quite a few black spots. He likes the cooler waters of the running streams, and is right at home on the gravel or stone bottoms. He is a far cleaner-cut fish than any of the other cats, and he puts up more of a scrap than the rest of the gang.

The channel cat takes nearly all natural baits. He likes the live minnow, frog and crawfish and a regular bass-casting outfit is the right dope for him. 
As an average weight he runs about four pounds, but they have been taken up to twenty, and eight or ten pounds of live channel cat can stir up quite a fight before you land him. He is naturally a bottom feeder and you must send the bait down to him to get a connection.

All catfish are very tenacious of life and it is well to kill them as soon as caught. 


\section{WHEN TO GO A-FISHING}

Of course, the best time to go a-fishing is when the fish are biting and, following the clew a little further we find that when the fish are biting is when they are feeding. There are many times when the angler comes in with the remark that " they wouldn't strike at anything, not even a nibble," or, "this lake is certainly fished out, I never raised a strike." The answer to all such yelps from the tired member of the fishing gang is, "the fish were not feeding," or in the vernacular of the angler, they were off the feed.

As to the time of day to expect the best fishing, taking the whole season as a basis, I have found the early morning fishing from four to eight o'clock and the late afternoon fishing from, say, four to eight, about the most dependable for all kind of fresh water game fish. The hours in between are the most barren for results, although one will get fish by working right through the day, as this is natural according to the law of averages, which applies to fishing as well as any other end of sport, pleasure or business. There are always bound to be some of the fish feeding any old time and some of them don't give a particular hang when they feed. 


\section{FEED IN THE SHALLOWS}

And in the early morning and late evening fishing we find the game fish in the shallows and the reason they have meandered shorewards is because the minnows are disporting thereabouts feeding on the small water insects so they will be well fattened for these same game fish to fill up their tummy. 'It is simply a law of nature; the game fish feed on the minnows because the minnows were put there for that purpose. Of course, this is tough luck for the merry little minnow who nips his feed from the unfortunate victims that light on the surface, but it's a case of hog eat hog, which ends up by bringing our average of heavyweights up to a higher point.

At the same time the game ones do not overlook the juicy frog that plays along the shore among the snags and trees that jut out into the water. The crawfish meets a like fate, being eagerly snapped up as he backs into the danger zone. All of these different varieties of feed are in the shallows, and the growl of an empty stomach naturally brings the game fish to the spot he knows will produce the toothsome morsels he loves. While he is feeding is the time to make the killing, even if it does bring you out before breakfast and keep you out after the evening chuck. 


\section{DIGESTS FOOD IN DEEP POOLS}

After making a choice of these varied eats the bass goes back to the deeper pools, there to lie and digest his meal, and at this time it is particularly hard to interest him in any menu no matter how beautiful in color and action. He just lazies around on the bottom, dreaming sweet dreams and not worrying at all about the high cost of living and the peace league.

You can interest them sometimes when they are way down below, however, but you have to send your bait right down to them and rub it close to their nose to make them come through with a strike, and at that I believe they strike at that time more out of fighting instinct than through hunger. For this reason I have found it well to carry a little touch of red on the lure, pork rind, minnow or frog that I send down for their benefit, and the added flash of a small spoon or spinner seems to wake them up a trifle.

\section{PIKE STRIKES ANY TIME}

I have found that the pike, pickerel, muskellunge and wall-eyed pike will strike oftener than the bass during the midday siesta; this is probably because these fish are more of a rustler or barbarian type than the bass, or have simply an instinct of com- 
bativeness with which the bass is not inoculated as much as the other rougher fighters of the fish tribe.

At night fishing it is well to use only the floating artificials and those of white make the best lure for the night feeders. It is work enough to handle a bait at night that rides the surface not to add to the tough-luck possibilities by having the artificial go down and hook up with the many snags of the underwaters.

\section{SHOREWARDS AT END OF SEASON}

As the season crawls along toward the end we again find the fish feeding in the shallows, and the early morning and late evening fishing are in strong. At the real tail end of the season the morning fishing produces better than the evening, and the game fish having felt the touch of winter in the colder waters, stick in the shallow waters for what warmth they can get from the rays of the sun that burn down in the shoreward reaches. At this period the bass are mighty hungry and feed right along in an effort to fatten up for the long rest during the winter, when they hibernate, the large mouth digging into the seed roots and mud of the bottoms, while the small mouth makes for the rocky crevices until the cold waves pass and the warm sun brings them back to action in April.

A good rule to follow is to fish early and fish late, or, fish all the time if you love the game and find 


\section{WHEN TO GO A-FISHING}

pleasure on the water. Of course, it is not all of fishing to catch fish, but nevertheless, we all like to bring home a fair string to show the rest of the boys that we are "some" fisherman. 


\section{THE FLOATING BASS BUG}

During the past three years the modern floating bass bug has come into favor as the real big bet in going after the bass of the running streams. Of course, the floating bass bug is not conceded to be the one and only fly method of getting the game fish, as the wet or drowned fly will take more fish throughout the season than the floater, but at certain times and conditions of waters the floating bass bug makes a winning lure.

Take a good bass stream with a little movement to it in the season when the insect life along the stream is in full flight, and particularly when there are plenty of butterflies, moths and grasshoppers on the wing, and playing the floating bass bug will fill the creel quicker than any other style of fly casting.

Many well-known fly fishermen have made killings in the past few seasons on the upper Mississippi waters around Alma about the middle and tail-end of August, when those waters are great for the small-mouth and fly, and it is from the use of the floater up in that section that quite a large part of its popularity has been scattered broadcast. 


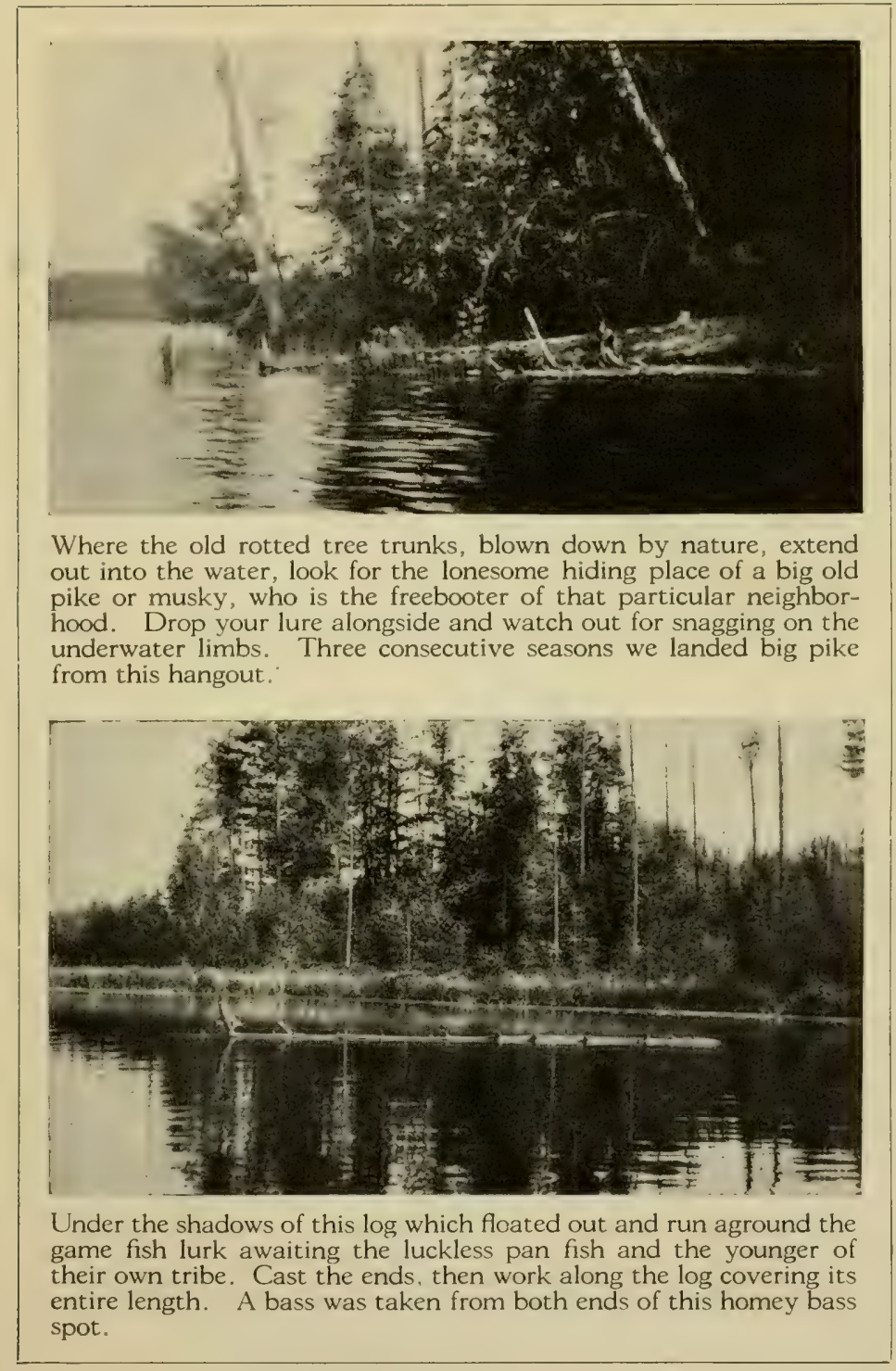





\section{TIED IN MANY- STYLES}

At first the tying of this bug ran along the old style and there was no set of patterns or standard styles, as in the old line of flies, of which there are something like 5,000 patterns from which a fellow can fill a flybook to his heart's desire and sometimes much to the amusement of the game fish tribe, who, no doubt, enjoy the variety of the baits and lures passed out to them.

When the bass bug started along the road to success as a winning lure in the fish-attracting game, some of the fathers of the sport gathered together and selected the best patterns. These particular bugs were named and grouped together as standards for the present as well as future fishing fans, and these patterns are now recognized in the fishing fraternity so that a fellow can ask for a certain bug and not wonder whether it will be a cross between a Black Gnat and a Yellow Sally, or a Whirling Dun and a Royal Coachman.

\section{A FEW STANDARD BUGS}

Among the standardized patterns that will be found effective lures on practically any waters are the following styles: Peet's Favorite, white body, brown stripes, white tail and wings; Dilg's Gem, orange-brown body, black stripes, brown and gray tail, brown turkey wings; Clark's Fancy, white body, 
red tail and wings; Zane Gray, gray body, stripes, tail and wings; Carter Harrison, brown body, yellow stripes, fox squirrel tail and wings; Wilder's Discovery, yellow body, red stripes, red and white tail; Doctor Henshall, brown body, red stripes, brown tail, red and white wings; Ref's Murderer, white body, brown tail, pheasant wings; Bob Davis, yellow body, tail and wings; St. John's Pal, red body, black stripes, yellow tail, mallard wings; Hadley's Choice, yellow body, black stripes, white tail, yellow and white wings; Dixie Carroll, natural body, golden pheasant wings and tail.

Some of these patterns are entirely tied with wings and tail of hair, while others are a combination of hais and feathers. It takes a fair-to-middling dyspeptic old bass to lie quietly and not make a smash at the wiggling life-like motion of the long trailing hairs of the tail and wings of these bugs. And when the water starts these hairs to moving the bug seems alive, and it is this action in the water that has made them the wonderful lure they are.

Casting the ordinary dry fly is about the most difficult part of the fishing art, and it takes an expert at wet-fly casting to step up into the dry-fly class, but with the floating bass bug the game is different. A fellow can drop into the hang of casting the bugs without much practice. If one is good at bait casting the bug casting is easy to acquire. You do not have to worry about how the bug will land on the 
surface, as it invariably drops down on the water with wings up and floating, like a real-for-sure bug would float if it happened to judge short on the distance and thus become fish feed.

\section{HOW TO CAST THE FLOATER}

When the bass are on the rise for surface feed, after the unlucky insect that cut his corners too close, then is the real time to give him a shot of the floating bass bug. It works the best on fast water, and, if cast up and across the stream so that it has a natural float downstream, the bug will not go far before a bass comes up and connects.

In making the cast it is well to study the current and try to work your casting water in such a way that the line, leader and bug will light on water moving at the same speed so that the weight of the line, if on a slower stretch of water, will not drag under the bug. In fact, it is well to cast the bug with a slack line, as this generally gives the bug sufficient floating distance by the time the slack is worked out of the line to ride along over some old bass' home.

Work the floating bass bugs so that they float down around the rocks in the waters, among the eddies alongside the pools and into the head of the pools from the swifter water running into them, where you usually find a big game fish that has preempted this location of easy feed and lots of it. 
That, of course, is what makes him big. Most anywhere that the bug will float in waters that are real bass waters you will find this a rather taking lure and one easy to handle. As it brings the surface strike, in all its glory, what more can a fisherman ask? 


\section{TAIL-END TROUTING}

At the opening of the trouting season the waters are, nine times out of ten, high and roily, filling the stream from bank to bank and rushing along, gathering driftwood, mud and sand, until it takes a mighty clear-eyed trout to do more than hope to see anything in the food line. What he does see is the worm and minnow. He is not even looking for a fly for the very good reason that he is bottom feeding, there being no flies in hatch on the waters that early, anyway.

Following the rules of nature, which are generally simple laws, the trout feeds on the food supply that the great ruler of the streams and rushing waters supplies. The worm is washed along from the banks where the swift water has loosened the earth and is carried downstream until a hungry fish with a big appetite and a small supply of food awaits the juicy dainty as it rolls and wriggles close to the bottom.

\section{MINNOW AN EARLY SEASON FOOD}

Most fishermen coming home from the early season trip to the trouting waters, that is the wise fish- 
erman who does not resort to "bunk," will admit that he got his fish with either the worm or minnow. This is especially so if he happens to bring home a fairly big one. He will not tell the story that they were simply crazy after his flies.

Until the insects begin to hatch along the stream side, the trout are not overanxious to come to the surface, but along through June and July the fly fisherman is right in his glory. As the waters fall down through August the fly game also quiets down. Streams that were full and rushing are generally mere skeletons of their former selves, and the water is clear and fine, which makes it easy stuff for the trout to see what is going on along his feeding waters. Not so often now do you find him along the open stretches. He has hiked away to the pools, along the cut-in banks where the stream has washed away a safe refuge among the roots that curl down under the water, by the driftwood and logs that have become wedged in the water, and in fact, any place that looks like a quiet safe place to hang about. For these hiding places I have found a Merino grasshopper a mighty inviting fly for the big trout.

\section{DRY FLY A WINNER}

And here also is where the dry fly comes into its own, and if you play it right you will get a piece of fishing that will make any other line of stream work look like a two-spot without any helpers. To the 
ordinary fly fisherman, who has never tried the dry fly, this end of the game looks like something a little beyond him.

Of course, during the June and July fly casting, the beginner could get his fish even if his casting was a bit clumsy and noisy. But for the dry fly stunt with the clear fine waters, and the August stillness of the woods which is so naked, and when sounds seem to carry farther and quicker, the casting must be done with more fineness and without the usual splash and shuffle in the waters.

In fishing the dry fly, no effort should be made to cover a big stretch of water, but the real effort should be to approach the pools or hiding places of the trout carefully and quietly. It is essentially necessary that such casting water should be studied before the cast is made so that the greatest chance may be had before giving the trout, especially the big ones, the scare before you get in your good work. A big trout may be lying even 40 feet away, just waiting for a nice fat little insect to come floating into his line of vision, when a splash through a careless footing gives him the high sign that it's time to beat it to a safer place until the danger blows over.

The right way to fish the dry fly is upstream, working into the water below the pools, boulders or refuge, so that you can make your cast up and slightly across the stream. This gives your fly a 
chance to float naturally downstream with the current, which is, of course, the object of the dry fly. In casting for the big fellow that you feel sure lies near the boulder, make the cast a little above it, so that the fly will float down and around it, in the swift little whirl of water that generally curls around such old trout hiding places. Although the trout is lying there waiting for just such an invitation to feed, the fly floating down takes him by surprise and he strikes like a smashing short-arm jolt of a heavyweight. If you fail to get your strike on the first cast do not make a second try at the same spot right away, but cast, say, over into the pool along the other shore, then afterward make another cast up around the boulder.

\section{WATCH THE SLACK IN LINE}

Care must be taken in pulling in the slack of the line so that the floating fly will not be drawn under the water by the weight of the trailing line, and an effort should be made to make the cast on water that is flowing evenly, otherwise should the fly be carried along more swiftly than the leader or line, it will be drawn down into the water, and the effect of a floating insect lost. The cast must be made lightly and accurately, and it is not at all necessary to cast as far as with the wet fly. In casting the dry fly do not raise the tip of the rod, as is usually the case in fishing the wet fly. This little movement, no mat- 
ter how slight, will pull the floater under the water, and the effect of the dry fly will be killed immediately.

At the same time do not begin stripping in the line until the fly has started down stream with the flow of the current. 


\section{THE BASS FAMILY}

Both species of the black bass family, the large mouth and the small, comprise the most popular game fish of our inland waters, and when it comes to favorites we have to pass them the blue ribbon as the most plucky, game and scrappy fresh-water fish any angler can hope to connect up with in many a day's fishing. Both large and small mouth are truly an American fish, American born and bred, and with the same fighting spirit that made the Boche yell "kamerad" when the Yanks went over the top.

With a good old pal at the oars to handle the boat and a husky black bass on the fighting end of the line, a fisherman has all the joys right before him that he will want from any other member of the game fish family. No other fish can equal the fighting dash of the bass.

His widespread distribution throughout the United States only serves to increase his popularity, for he is found in most lakes and streams from the Rockies east to the Appalachian chain, and in the North and South. Both species are plentiful throughout the entire Mississippi basin, and in the cool, clear, spring-fed lakes and streams of northern Wisconsin, Minnesota and Michigan he seems to I 28 
have selected his permanent abode and base of operations and hung out the "at home " sign; for he sure is found at his best in these waters.

\section{BASS BREEDS FAST}

Another thing we can be thankful for and that is the fact that the bass is a thorough disbeliever in race-suicide. He has a highly developed paternal instinct that makes him realize the necessity of protecting his youngsters until they are able to scurry around for themselves and keep out of the way of the big fellows, who are ever ready to cut their percentage down.

The spawning season of the bass varies in different sections of the country. For instance, in the northern middle states June and up into July are the months they deposit their spawn, while in the southern middle states the season begins sometimes as early as May.

It is interesting to note that the small mouth bass prefers to deposit her spawn in nests prepared on sand or gravelly bottoms, along bars and on rocky ledges, while the large mouth usually picks the moss beds, brush heaps, underwater logs or windfalls, or the muddy bottoms among the underwater weeds.

FEMALE SMALL MOUTH BUSY MOTHER

The female small mouth stays right in the vicinity of her nest constantly during the hatching period, 
continually fanning to keep the sediment and debris from settling on the nest. The large mouth deserts her nest as soon as the spawn is deposited and returns when the little fellows are about ready to come into their own, when she jumps right onto the job and gives them the protection they need against the voracious fish that hover near the nest, ready to wipe out the family when opportunity offers.

When the young fighters are a week or two old the roaming instinct begins to show itself and they desert the nest, and finally the wise old parent bass leads the timid ones off to the shallow waters, where they can protect themselves from the larger fish by seeking protection among the weeds and brush heaps.

When they get to be a couple of inches long they begin to show their audacity and their voracious appetite by making successful war on the minnows in their vicinity. It doesn't take long to conquer their home waters, and to satisfy their almost insatiate appetite they will often attack minnows larger than themselves. It is this endless battle for existence, this survival of the fittest of the underwater citizens, that trains them into the plucky, fearless fighters when they begin to take an interest in our lures.

The average family of a pair or basses runs from I 0,000 to 20,000 little baby bass. Of course, only a small proportion of these ever live through the skirmishes and scraps among themselves and the for- 
ages of the larger fish, but enough do grow up to let us know the black bass still exists when we put the lure in the right spot.

\section{HUSKY ONES GROW. BIG}

It doesn't take long for the young bass to learn that their brothers make delicious food; and they are regular cannibals in this respect. In a government hatchery several years ago out of 100,000 bass hatched in the spring only about 30,000 were left when they were removed in the fall for planting.

The majority of those that lived through the cannibalistic era weighed from two to three ounces, although 500 pushed the pointer up to around half a pound. In the latter bunch we probably will find the future granddaddies of the water trails that keep the records for size well up and make a few lucky fishermen happy.

With good feeding conditions it takes about two years for them to reach a length of ten or twelve inches, and from then on they take on about a pound of kick every year. Their growth is wholly dependent on food conditions and range of water.

The average weight of the small mouth in this section runs from one and a half to three pounds, although now and then one with a case of "elephantis " is brought to gaff. The large mouth averages about a pound more than the small mouth, sometimes being caught up to eight pounds. 


\section{THE MUSKY GAME}

Taking into consideration weather conditions, habits of the fish and water facts, we can figure that June musky fishing follows closely, but does not quite equal, fall fishing in September and October, with July next and August the quietest month of all. This schedule is also arrived at through records of the muskellunge caught during a number of past seasons, which also shows that the largest of the tribe have been caught in September, although the early season muskellunge stacks up to a pretty fair weight. However, he seems to be more numerous in the early season than given to excess weight. It may be that the heavier, huskier old "pops " of the tribe do not get their fighting clothes on until a little later, but the younger element certainly are a fighting crowd early in the season.

\section{RUNS TO GOOD WEIGHT}

By this we must not get the idea the younger ones do not run to good size; many are caught in June of the fair, fine weight of from thirty to forty which, by the way is a muskellunge of size well worth fighting. There are many old scouts at the musky game 
who would be tickled to death to connect up with a thirty-five pounder and fight it out at any old part of the season.

Those that come above forty pounds are few and far between, and these fellows have been invariably hooked in the late season. While on this part of the dope sheet of the past performances of the musky it might be well to state that the big majority of these real large ones have been caught by amateurs at muskellunge fishing, which fact must be humiliating to the victim's family.

After swimming around for twenty or thirty years avoiding all the varied lures of many fishermen, it is tough luck to fall for the rough work of a beginner, and not show speed enough to combat a wild-eyed fisherman who is probably suffering from " musky fever " during the game.

\section{TROLLING AND CASTING}

The biggest end of muskellunge fighting is done via the trolling method, although casting for his nibs has come stronger each year, particularly during the last three seasons. In casting for muskellunge using the ordinary bass casting outfit, with a slightly heavier line, say a twenty-pound test instead of the usual twelve to fifteen of the bass game, it is somewhat of a job to cast the heavier spoons and the black sucker which is generally used as a natural bait. To cast an eight-inch sucker is some work and 
hard on the rod as well as the arm and after a few casts the boys usually go to a shot of trolling.

The use of extremely large lures in casting for musky is not as necessary as most fishermen probably imagine; many large fish have been taken on the smaller lures and spoons of the bass outfit. I have found a good long strip of pork on a hook rigged up with a small Lowe-Star spoon of the ordinary bass size very effective, and this bait can be cast to the heart's content without putting a crimp in the casting arm. During last season I seldom used a rig larger than this for casting the pork strip and had good luck with it; in fact, for some three years I have used the small-sized spoon either single or tandem in muskellunge casting. Of course, for the trolling game the larger Lowe-Star, the No. I-O, has been far more attractive, caused, no doubt, by the fact that the fish are attracted from greater distance with the trolled lure than the cast, as one generally places the bait with the cast in the spots that look like natural musky retreats, while the trolled lure drags along all waters besides covering the likely spots.

\section{BASS-SIZED PLUGS BEST}

Many large plugs are being touted as musky baits for casting. Most of these plugs are entirely too large for clever handling, although they make a 
fairly good trolling lure. However, for my own part I have found the small bass plugs just about my dish for successful work with these rough fighters. Not only are the larger plugs armed with an oversupply of trebled hooks, hard to handle in the cast, but you will find that you lose more fish than with the smaller ones, as the musky gets a chance to tear out the hooks of the larger lures because they give him a leverage that the small one does not. With the small bass plug he is generally hooked with one hook and that at the side of the jaw which gives him no purchase on the plug to help tear out the hook. And hooked in that manner gives him a chance to put up a scrapping fight that is worth going miles to enjoy.

Last season I had quite a nice run of luck with the small bass plugs, the Pflueger-Surprise minnow of the green back, white-bellied color was a wonderful worker among the musky; the darting minnowlike swim of this plug, without any metal spinners to make it do the darting movement, was just a little too much for the inquisitive fish.

\section{CASTING SOMETIMES BEST}

For the late season musky game I believe that the angler will find the casting stunt more effective than trolling. More water can be covered and at the same time the musky are more on the alert at this 
season and more active and the cast lure is more likely to attract his attention than the deeper-trolled spoon.

The five- or six-inch minnow used with the ordinary bass spoon is also a good, attractive lure for the late season musky. 


\section{FALL FLY FISHING}

The real snappy fighting fish is the fall-caught water native. It is a muchly discussed question as to what gives the game fish the additional peppy fight in the fall. Some say that the bass in particular are fattening up for the winter hibernation and for that reason mighty active after a feed. Others claim that the natural feed has somewhat thinned out and most any kind of eats interest the fish. Naturally with a scarcity of favorite foods, the fish fights like the very dickens to retain any that he is lucky enough to snap his jaws upon. From my observations and study, I have come to the conclusion that the cooling of the waters in the fall is really what makes the game fish the lively scrapper at that season.

Remarkably so is the fight of the bass of the stream, in addition to his regular hot fight at all seasons, due to the fact that he has grown up in a running stream against whose current he has through necessity been compelled to fight in order to live. The cool fall days supply a lot of snap to the air, which works into the water and electrifies the old bronze-backed warriors into renewed vigor and dash. 


\section{FLY FISHING FULL OF THRILLS}

After a bass has developed his fins and tail, fighting a fast current in a stream for a couple of years, he is a fine antagonist and to play him on a fly rod in the fall will bring thrills to the fisherman that he never figured were part of the game. And in the fall fly casting for bass on the stream is right in its glory. The bass take the gayly-colored feathers with a speedy strike and like it.

Fly casting for bass is not the extremely difficult art that some of the anglers would lead us to believe. Most any fellow who has cast the plug, pork rind, minnow, frog or spoon can acquire the knack of handling the fly rod with a little practice. Of course to be an expert at playing the fish requires stream work, but that comes naturally after a session or so with the snappy fighters of the moving waters.

\section{FISH WHERE THEY FEED}

About the best little piece of fishing insurance in any angle of the sport is a knowledge of the fish and their habits and where to find them and when. Casting with the fly or any other bait or lure in a piece of water in which a game fish has no reason for loafing around, never fills any creel or stringer. Fish the likely looking spots where your knowledge of fish and water conditions tells you that a livewire bass would find a.good feeding place. That 
is the kind of a location you will find worth while. You get a strike at your lure due to the fact that the game fish is on the job where he thinks he can locate a meal.

In fishing the wet or sunken fly for bass, fish particularly the pools. A productive spot is the head of the pool just where the faster water of the riffs or rapids runs into it, also the shallower pools at the head of the riffs and into the eddies formed alongside of the rapid waters. Cast in the swirl of water made by the boulder that sticks up out of the water and the edges of the logs and brush heaps, not overlooking the pools made by the current as it cuts into the bank near the bends in the stream.

\section{CAST DOWNSTREAM}

As the bass lie with their heads upstream, it is preferable to fish downstream. At the same time it is easier to wade downstream than up against the current. The bass is far more easily frightened than the trout, and the wise fisherman keeps out of sight as much as possible, casting a long line on the streams that are wide and clear, or "fine" as the regular fly fisherman terms it.

For a selection of flies that are usually good on most any stream, let the fly book contain Queen of the Waters, Grizzly King, Coachman, Lord Baltimore, Professor, Montreal, Yellow Sally, Silver Doctor, Rube Wood, Seth Green, Ferguson, Mc- 
Ginty, Red Ibis, White Miller, Parmanchee Belle, Emerson Hough and black, brown and gray hackles. There is enough color and combination in this outfit to satisfy most any bass and any condition of water or weather. For the bright clear days the darker flies are usually the best bets, while on the dark days and for the evening fishing the light-colored flies seem to make the most impression on the bass. Have the majority of your flies tied on the 2 or 4 size hooks for general fishing, with a few on 6 or 7 for use when the water is low and clear. For the rough and fast water the bright-colored flies are winners.

\section{USE A SPINNER WITH FLY}

The fly is often made more attractive to the game fish by the use of a small spinner. In selecting a spinner make it a point to keep it small and light, otherwise it will soon put a kink in the tip of your fly rod. The spinner of aluminum slightly smaller than a dime, is a good one, and it can be had in the dull finish of the original metal or enameled black. Both these colors are effective. I have found the black spinner particularly good for the late evening fishing, and on a bright day.

Often the fly can be made a striking good lure with the addition of a very small strip of pork rind. Not the big strip of the regular bait caster, but a little cutting off of one of these strips, say about two inches long and a quarter of an inch wide at the 
thickest part, then tapering down to a point. The wiggle of this pork strip at the tail end of a fly often makes the game fish come through with a strike when nothing else seems to interest them. 


\section{THE FALL FIGHTER}

After the frost has nipped the leaves turning them to the many hues of gold and yellow with the glorious red of the maples sprayed in among the dark green of the pines, then the game fish are at their best. They seem to become filled with the fighting spirit that puts them right on edge for a wonderful scrap that fills the heart of the real fisherman with gladness, and also this rapid scrap of the game fish puts the fisherman on edge to show his finest tackle skill to outwit the wily fight of his finny victim.

In the fall, quite different from the hotter days of midsummer, the day can be bright and clear for good fishing. There is no need of waiting for an overcoat day to expect the best results in quest of the game ones. The bright sunny day is even better than the darker, cloudy one. The days of real Indian summer are balmy and clear with a good hot sun to cheer up the fisherman and make this choice piece of sport more enjoyable.

\section{ALL LURES USEFUL}

All the lures of the early season game come into play and can be depended upon to draw the strike from the game fish. The wobbling surface and 
semisurface plugs are interesting baits. In the color end the whites with red heads are good as well as the green-backed ones with the white underside and the natural finish bait with the scale effect, first brought out last season, is a "darb" as a real live bass coaxer.

On a bright sunny day this week I watched a fishing "pal" play and land a ten and three-quarterpound wall-eyed pike that had struck his white Wilson wobbler with red flutes, and some fifteen minutes later a four-pound pike cracked the same old bait with a tremendous strike for a fish of that size.

Fishing from the same boat, I was fortunate enough to land a three-pound bass and a six-pound pike in the same waters, and during the same period, with a natural finish Pflueger-Surprise minnow. Which merely goes to show that the fall game fish is not so particular as to the color of the plug as he is at times during the midseason fishing.

At the same time another pal fishing the same waters had exceptional luck trolling with a No. 4 Lowe-Star spoon decked out with a feathered hook and a trail of pork rind. The most of his fish, however, were pike, so commonly called pickerel by the fishermen. The fish ran to good size, and a string of eleven pike averaged six pounds, the largest a twelve-pounder, all of which put up a fairly game fight when landed on a four-ounce split bamboo bait casting rod. 
All of these fish were landed during midday fishing, with the sun doing a fair to middling hot burn, a day that would not stack up one, two, three as a good fishing day earlier in the season. Nor at this season is it necessary to get up with the early morning rooster in order to feel sure of a good string of fish. As a usual thing, I can count on good fishing right through the entire day with no special time standing out as particularly strong. The fish seem to be on the feed all the day and about as active at all hours.

\section{BASS LURKING IN BAYS}

Many bass can be picked up by trolling across the mouth of the smallest bays and inlets as they seem to congregate there on the still hunt for minnows and pan fish. A fair-sized minnow, shiner, chub or sucker makes an excellent trolling bait and a six-foot gut leader should be used to bring out the good points of the bait. Two or three small split shot sinkers will take your bait down where the fish swim around in search of their feed, and a nice, easy speed of about a mile and a half an hour is fast enough for the boat. Many fishermen speed up the boat too fast in trolling and then wonder why the fish are not striking. Trolling too fast is taking the bait away from the fish and at the same time exceeding the speed limit of a swimming minnow, which your bait is supposed to represent to the waiting fish. 
Locating the feeding places of the game fish is necessary in any kind of fishing at any part of the season, but it is just a trifle more necessary during the fall fishing, however. When you do locate them at this time you generally find that you will get more fish from a good feeding ground than you can at any other time of the year as the fish appear to travel in closer formation then than at any other time.

\section{NARROWS A FERTILE SITE}

One place in particular that usually produces well in the fall is the narrows, or thoroughfare connecting two lakes, not necessarily a long channel, but the usual small connection found between nearby lakes. The game fish have a habit of swimming around this spot to feed up on the pan fish that cross from lake to lake and fishing a formation of this kind generally brings results. Also the waters of the inlet or outlet of the lakes stand out as interesting fishing waters as much feed is found here by the larger fish. Taking it from all angles the Indian summer stretch of fishing is as good as the early season sport, better than that of midsummer and for real pleasure on the water it is far ahead of any other fishing time. Your chances of fighting a real big one are many times better now than earlier in the season, as the old grandfathers of the game fish tribes are certainly active and on the hunt for a big feed before they turn in for the winter. 


\section{THANK THE PICKEREL}

Of the whole layout of fish that bring the smile to the face of the expectant angler, be he the graywhiskered old " regular" or the knee-pants, bent-pin sport, there is no species that can be counted on to hit the bait more consistently than the pickerel. And most any kind of water is good enough for him to swim around in. The sluggish rivers and muddybottomed ponds are pie to him, and he grows fat and husky at the same time. He is quite Rooseveltian in his family theories and raises a big gang every season. For this family trait and the fact that most any water is home to the "pick," he will be with us for keeps and make much joy for the angler who is not too fastidious to take a shot at him once in awhile.

Many fishermen cuss the pickerel and think him small game for a "real" angler, but a live bunch of pick on the bait end of a line is some sport if you give him a chance to travel a little and play him according to the rules of the game. A I 5-pounder will make some of the crowd pant for breath if you play him until he comes to the boat bellyside up. 


\section{SWIMS UNDER A MONIKER}

In the first place, the pickerel is kicking around under the wrong name. He is really the pike and belongs to the same family as the musky, although not such a husky scrapper as his cousin. In shape and contour he closely resembles the musky, but is covered along the sides with spots or daubs a trifle longer than they are'wide and running the long way of the body. The true pickerel, his other cousin, very seldom grows over six pounds and he is more spotted in a design that works all over the body and the design is more of a continuous chain effect, while the spots of the pike, so commonly termed pickerel, are distinct daubs against a darker background generally of greenish yellow along the backs and sides blending into a whitish cream-colored tummy. The conditions of the water and the mineral formations as well as the underwater growths naturally govern the colorings of the different fish inhabiting those waters, this applying to the pickerel as well as other fish.

\section{HE STAYS IN ONE SPOT}

Like the musky, the pickerel is a lone hunter, he is a moody sort of a guy and he don't like company. He will locate a likely looking feeding ground, and if of size enough to defend it will stick around that place all season. He is not much of a rover, and 
if you get a good strike from one of them in a certain location and then lose him, you can row around the lake and come back and feel confident of finding him in the same waters and willing to take another chance at your bait.

I know of one I 8-pounder that had a hangout in a little cove close up to the narrows and he stuck around that same piece of water after being hooked three times, until at last he struck twice on the same day and joined his ancestors in the happy fishing waters.

This pick was just wise enough to immediately slip below and snag the line on a big old pine that had wind-fallen out from the shore and twining the line among the stubby branches he secured leverage enough to break the line or tear the barbed hook from his undershot jaw. That I know this, is because he pulled the trick on me in the morning and fell for my pal's spoon that afternoon, and he still had my golden Lowe-Star spoon firmly set in his jaw when the pal brought him to gaff.

Minnows, pan fish, bass, his own relatives and the luckless kicking frog make. up his menu and he feeds most any time. Of course like most game fish he feeds heaviest in the early morning or in the late evening, but he keeps right on throughout the day. If your bait goes anywhere near him, that is, close enough for him to get but a fleeting glance at it, he will come across with a strike. But you've got to 
throw it to him or troll it past his hangout. He lies, by instinct, in wait for the passing fish and darts out with a swirl, striking the unlucky pannie with a powerful closing of the sharp-toothed jaws that sometimes cuts the innocent bystander in two. Then he darts back to his loafing place and gulps down his victim, ready in an instant to go after the next one.

\section{BIG EATER STRIKES SMALL FLY}

Last season I landed an II-pound pike on a fly rod, after he had taken a red ibis fly decked up with a small spinner. The rod was a trifle heavier than the usual trouting rod, being used mostly for bass, but it was a sporty fight from the strike to the final kick, with the battle nearly in favor of the pickerel at that. After an hour and ten minutes of back and forth stuff both hands were badly burned by the line and the rod had a decided set in the second joint and tip.

This pickerel probably struck that small fly and spinner from pure cussedness, because he was filled to the guards with pan fish and topped this lunch off with a wall-eye pike that weighed close to two pounds. The wall-eye had no doubt just been swallowed prior to the strike at the fly, as he was in perfect condition. With a stomach stretched to the extreme, it surely could not have been hunger that caused this I I-pounder to take a crack at a small bass fly. 
To get real sport out of the pickerel, go after him with a sturdy fly-rod, and the steel one makes a humdinger for this game. Or troll for him with the fly-rod, and if you are one of the fellows who have never been able to get a real "kick" out of fishing for the pickerel, it's a bet that you will have your hands full playing him on a ten-foot rod and you will not land every one you strike at that. 


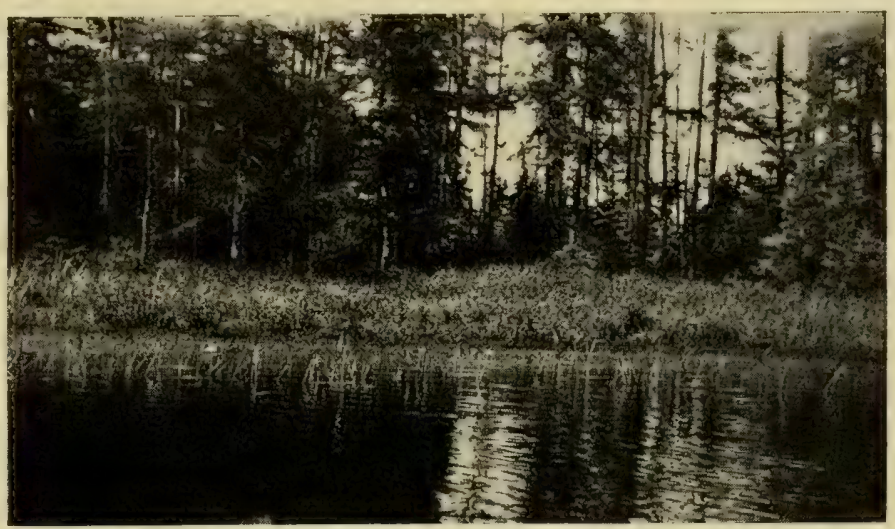

Off the edge of a tamarack swamp, here among the rushes and weeds, which go deep down in the water, we found good pike fishing, making the cast right into the rushes and reeling the lure through them. This is good feeding grounds for pike.

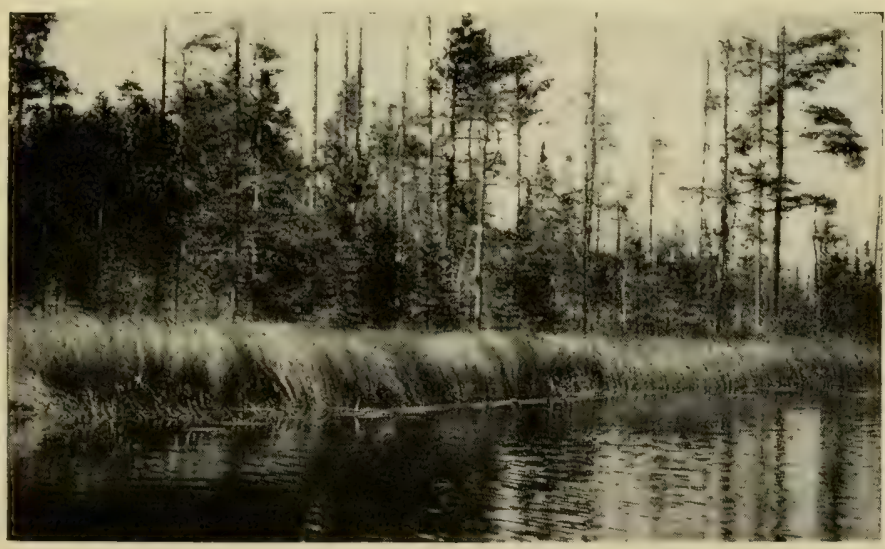

Right along this shore and into the pockets the pike were feeding strong. The water runs back under the wire grass and is a good breeding place for minnows and pan fish, right juicy morsels for his pikeship. Cast close into the edge and reel medium slow. 



\section{"BUSTING" THE RULES}

There are a lot of fellows who go after the festive game fish who are overlooking a little fishing that usually brings good returns to the stringer, and that is fishing when it rains. As soon as J. Pluvius mixes up the cans and accidentally kicks over a few, spilling the rain down in big gobs, most of the boys bend the back rowing to shore, to loaf under a jack pine until things clear up. That's where they make a big mistake. I have landed some of the finest fish an angler could wish for when the rain was beating a rippling tattoo on the water's surface.

A few weeks ago while fishing in northern Wisconsin, a pal and I held an hour's session with the fish families of a small lake during one of the heaviest rains it has ever been my luck to be in. There was a strong southeast wind blowing quite a gale and the rain hit the surface with great force, the water spraying and blowing into the face so heavily that it was impossible to talk. At times I thought the old scow in which we were fishing would not make shore as she was taking water from below and above, but we had as nice a dish of big pike fishing as comes to the luck of a fisherman. 


\section{BIG FELLOWS OUT IN RAIN}

It was some sport landing those pike without the help of a gaff or landing net, as we had hiked over to the lake more on an exploring expedition to look the water over than to fish. We landed six pike running from six to nine pounds during the heaviest part of the rain, and on nearly any old plug that we cast to them. The rain evidently chopped up the surface to such an extent that the pike took any lure in any color or shape.

The seventh pike landed was a twelve-pounder, and he fought with savage runs each time we brought him to the boat, and then doing quite a swim around the half-filled boat after we landed him in. Not being prepared for fishing, having no stringer along, we had tied the other fish on a tripled piece of line, trolling it alongside the boat.

Here we were slapped in the face with a darned good lesson on preparedness. A few moments after trying the big fellow on the improvisèd stringer, I glanced back at the fish and lamped them slowly moving away from the boat. Yelling the bad news to the pal, he made a frantic grab down into the water and salvaged three of the fish still remaining on the stringer, the big one being the first to make a get-away.

He had simply slashed a couple of times across the line with his half-inch teeth and cut it. Which 
only goes to show us that when you go a-fishing take the necessary tools of the trade along if you expect to bring back the bacon. A stringer seems a very small part of the kit, but to be without one is about the unhandiest thing on the water when you start landing the underwater battlers.

\section{"BUSTS" SOME OF THE RULES}

Another one of the rules of the game was shattered the same afternoon. We all know that quiet and stealth on the water is good for fishing, we should use as much care as possible when casting in the boat and not make any more noise than absolutely necessary, so that the fish will not become frightened and make haste to other waters.

Returning to the head lake from our rainyweather piking expedition, four of us passed a pleasant hour swimming around a big rock jutting out of the water at the far end of the lake. The water was fairly well kicked up during that time, and a fellow would think that the game fish had hurried off to the other end of the lake during the disturbance.

One of the boys picked up a rod, made a cast within ten feet of one of the other fellows swimming in the water and was some surprised when a three and a half pound bass hit the bait with a crack and started away with it. According to all the rules of war, the bass should have been in their 
dugouts, but in the fishing game you never can tell when all the rules of the deck will be shot to pieces by the frisky game ones themselves.

At times you must go right into the weed beds to get the bass, as they often swim around in there for a dessert of fat little minnows after the weather heats up and the little fellows have kicked into the weed to feed off the minute animal matter and the smaller winged bugs, gnats and water moths.

On this same trip we had found fishing a trifle slow along the edges of the weeds and in the open pockets, the stringers showing up fairly lean. I needed a few action snapshots of casting the close-in waters and the pal was drifting in slowly with the canoe to the right position. He was not thinking of the fishing game other than to get where he could do the best in front of the camera; his bait, a frog, was trailing along slowly about eight feet behind the canoe and right through the weeds.

\section{SUDDEN, UNEXPECTED STRIKE, EXCITING}

When you get a strike just about the time you are least expecting it, you are usually "flustrated" for a second or so, and "flustrated" is a poor word to express the condition of the pal when a big pike took the frog and started south with it at a fast speed. The pal gave him the barb and his pikeship came to rather suddenly and instead of a few still pictures of bait-casting into the weeds, I had a roll 
of as lively action pictures of an excited angler fighting and landing a seven-pound pike, while keeping his balance in a cranky canoe, as you will meet up with in many days' fishing.

This was a tip we needed and we played the weeds, right into them with the weedless hooks, the rest of the trip to good advantage. 


\section{SKITTERING FOR PICKEREL}

Although the pike and pickerel can generally be counted on for a strike all through the season and at most any time in the day, with, of course, a trilling slowup during the hotter days of August, when the teeth and gums are in bad shape, one is far more likely to be successful in landing a good string of picks, or one or two real big ones in the fall than any other variety of game fish. Right here, perhaps, the bass or trout fisherman will oar in with the remark that the pick is not a game fish, anyway - a question that is always open to debate - and who wants to fish for the "snake," anyway?

For the fellow who is satisfied to hook a few picks now and then, and especially when the other game fish are quiet or out of season, let me dish up the dope that the pickerel caught on the right kind of tackle puts up a fair to middlin' fight, and it is not every one of them that is landed at that. This goes for the titled expert or the tyro at the sport of tricking the game ones into landing distance. The pick taken from the cooler spring-fed lakes fights with more speed than the one taken from the more sluggish waters of the mud and marley bottom lakes, 
while the pick from the running streams is a rattling good fighter and needs no excuses to any angler for the sport he affords.

\section{NOW IS PICKEREL TIME}

November is a good month to try out the pick. $\mathrm{He}$ is just as much on the hunt for the chub and frog or anything else in the feed line as in the summer. $\mathrm{He}$ is a tireless feeder, a sleepless prowler after the goodies of the waters and he feeds right along after the ice covers the surface. Seems that feeding is his sole desire. He even takes the bait through the ice and likes it served cold. This is more than you can say of some of the gamer fish, and we thank him for his habit.

If you have ever had the joy of passing a vacation on a farm in the youthful days agone, you probably "went a'fishin" " with one of the natives, and although his knowledge of the true sport of angling was no doubt fairly limited, it is a safe bet that he brought home the bacon.

And it is also probable that he used one of those long cane poles, somewhere around fifteen feet over all, with a length of line about as long as the pole tied onto the small end. In the way of hooks, a few of those old "ten for a penny" suited his fancy, and a minnow or frog, with a strong preference for the frog as a favorite bait. He certainly could toss that bait out in the water and work it around 
the boat in a way that made the pickerel and bass step right up and join the crowd. That little method of interesting the fish is called skittering, and during the fall has been productive of many fine fish.

\section{SKITTERING TACKLE SIMPLE}

Bringing the skittering game a little more up-todate in the matter of tackle we can select one of those jointed cane poles of, say, I 5 feet, which is easy to pack on the train, or a long steel still-fishing rod of $\mathrm{I} 2$ to $\mathrm{I} 4$ feet. The ordinary bait-casting reel can be used in order to give more sport in landing and playing the fish, although the natives at the skittering game do not use a reel. The use of a three or six-foot gut leader looped onto the No. 2-o Sproat hook saves the line from being torn by the sharp double-edged teeth of the pickerel.

With the above outfit you can skitter to your heart's content, with an even chance of getting the fish to take a look at your bait, which can either be pork rind or chunk, minnow, frog or perch belly topped off with about a No. 3 Lowe-Star spoon. And it might be well to tack on a little color to make things interesting, either a short end of red yarn or a patch of red wool, as the pickerel seems to be a trifle susceptible to a dash of red in his menu.

Skittering is not a difficult thing to learn, although there is quite a knack to pulling the bait through 
the water. However, there is no thumbing of the reel on the toss out of the bait. As a general thing the game is played from a boat, although I have often found that by skittering a bait off along the edges of the marsh grass, weeds and pickerel grass along the shores or in the narrows, that the fish will strike it with a smash as they seem to figure it out that a piece of feed is getting away from them and they must take it quick or lose out in the deal.

\section{EASY TO ACQUIRE SKILL}

Let your boat drift along in what looks like good pickerel water and raise your rod in a vertical position with just about a rod length of line off the reel, then let the bait swing out to its entire length, without casting, and lower the tip of the rod to about 45 degrees. Allow the bait to sink slightly below the surface; then jerk it along with short, steady pulls, and as a rule working the bait entirely around the boat before another toss is made. Jerking the bait along in short, steady pulls seems a remarkably easy thing to do, but after you get a little practice you will realize that some skill helps make the bait move in a natural way through the water.

When the fish takes the bait give him a few moments to hold it before striking, otherwise you will probably tear it away from him without setting the hook. I find that a spoon hook with a trail hook snelled on is about the best thing in the hook 
line for this style of fishing, as you always save the short strikes with the trailer. After setting the hook give him a run of line, because the first thing the hooked pickerel thinks of doing is to make a long run away from the hook, and if you have, by luck, connected up with a big pickerel, landing him on the long bending rod will be quite a piece of sport, and something in the fishing game that no fellow need feel ashamed of doing. 


\section{CARE OF THE FLY TACKLE}

Naturally, the careful angler looks well after his tackle at all times in order to keep it in the best of shape so that every little part of it will stand up when the time comes to land the big one he is always looking for. But now, with the high prices on tackle, as well as everything else, it is a matter of practical economy.

Even at that the true follower of the stream and lake takes much pride in the condition of his outfit and nurses it along like a pet. The right kind of attention to a line will make it last quite a little longer than you would suspect. Take as an example the fly-casting line, which is either of the enameled variety or the softer vacuum-finished one that tops the highest price in this end of the line outfit. To leave the enameled line on the fly reel, closely wound, all winter, will give it a series of curves that will make it practically impossible to cast and lay a straight line on the water the following season.

\section{GIVE THE LINE A THOUGHT}

It is good practice while fishing via the fly method to unwind the enameled line each day and wipe it off with a cloth, to keep it dry, and then hang it 
up on a peg at camp or lay it loosely on a flat surface until needed the next day. With the vacuumdressed line it is necessary to keep it in first-class shape by greasing it once in awhile with deer fat, and say, boy, there is an awful lot of satisfaction in casting a well-greased vacuum line. This line is soft and makes a wonderfully smooth cast and lies fine on the water, the grease making a floater out of it.

At the end of the season the enameled line should be taken off the reel, coiled in a loose coil about the same size that you find it on the card when purchased, and then, to keep it right, just slip it into a glass mason jar and screw on the top. This keeps the little old moths away, puts it in an airtight bed for the winter and at an even temperature, which is good for any enameled line.

\section{TREAT VACUUM LINE WELL}

For the vacuum-dressed line, give it a good wipeoff, run it through your grease pad, wipe off the surplus grease, or let it on, as you have a mind to, and curl the line into a large, loose loop, then hang it way up out of danger in the coolest closet you have. To make a real dinger of a hanger just drive a nail in the molding, slip an ordinary spool over the nail and the line over the spool. This keeps the line away from the metal nail and does not make the top curve of the line too sharp. 
You can also secure a small hoop with the outer side bored out which is made especially for keeping lines right during the layoff. When a fellow figures that a good line now costs from $\$ 5$ to $\$ 9$ and is scarce at that, it behooves him to give it a little care.

Of all the rods the fly rod calls for more care than any other and it should have good care anyway. It is a delicate tool, and when one has a fly rod that just suits his cast, in weight and action, it should be fondled and treated like the good pal it is. Usually a fellow gets so used to the handling of a favorite fly rod that to replace it would take much time and trouble, not to mention the money outlay. Many of the boys have rods that could not now be replaced at double the money and with the growing scarcity of tackle, getting just what one wants in the rod line is a matter of some effort.

While on the subject of rods, here is a quiet tip for the fellow who intends to make a rod during the winter - get your fixings now. Go on a quiet scout for ferules, guides, tips, buttgrip and wood. It isn't a bad idea to look over some of the cheaper rods, made a year or so back, and buy one up at a bargain, using the metal parts on the rod you make.

\section{OVERHAUL AND VARNISH THE ROD}

When the fly-fishing season is closed for the season it is a good plan to give the rod an overhauling before putting it away for the winter. I generally 
take the rod and hang it up for a few weeks, and then give it a good look over, replacing all the loose silk windings. Give it one coat of varnish for luck, then at the opening of the following season give it a couple of more coats of varnish, as it is essentially necessary in order to keep a rod right to keep it varnished.

At the end of the season it is well to take the tips and second joint and hang them up by the lightest end with a weight on the other end. Leave them this way for a few weeks and any set or kink will be removed. Keep the rod during the winter in a cool, dry place. I have often jointed my rods and hung them from the tip by a small brad driven in the molding in the closet. If you let them remain in the case, do not tie the case strings tight nor stand them in the corner, but let the case strings loose so there will be no pressure on the rod joints, and hang the case up on a hook by the top strings, allowing the heavier ends of each joint to be on the bottom.

Flies, those great little coaxers of the moth tribe, when carelessly put away, can be protected by placing them in a mason jar. Slip in a few moth balls for company, and be sure and have the rubber ring on the jar before you screw on the lid as a last protection against the moth, which can get into places far smaller than you anticipate. And a regular supply of flies are too expensive for moth feed.

The fly-casting reel is not as intricate as the bait- 
casting tool and requires less care. About all you need to do is to take it apart, clean out the sand and caked oil, give it a bath in kerosene, wipe it dry and re-oil, then slip it back into its case, with the knowledge that it will show up bright and early for the openers in the spring, when you take your next cast at the squaretails. 


\section{KEEPIN' UP THE SUPPLY}

"In twenty years of guiding, to-day has been the least enjoyable that I have ever put in on the Black Lake String," mused Earny Wendt, guide extraordinary, as he kicked a log close up on the fire in the main cabin where we were burning a bit of the weed in our old cobs. "And here's the reason, oldtimer," continued Earny, " the chap I had out today never had the right education in the fishing game; he sure has started dead wrong. Seemed to me the whole thing that worried him was getting the limit. He got them, of course, but he netted a bunch of little fellers that just skinned past the legal size that should be back in the water attending the thirdgrade bass school. Now the Doc went over the same water the day before and brought in five bass that tipped the scales just short of fifteen pounds, and he threw nine back into the water to grow up. There's a lot of missionary work to be done with the fellows just starting into the great game, and the one big thought in that work is to impress 'em with the fact that they ought to throw the 'little fellers' back. I do hate the sight of a tape-line fisherman." 
There sure is a heap o' truth and reason to that remark of my old-time guide and friend of the water trails, "throw back the little fellers." Every fisherman toasting his shins around this camp-fire should make it a point to see that the fellows new at the game get the right start and pass along the info to be moderate in their demands from Nature's storehouse and to take only the fish they need and not to stretch the poor little tail-kickers in an effort to make 'em meet the legal requirements for size. A powerful lot of those same little bass will grow up into sure-fire old he-wops with a kick in their tails that will send the joy jumps right up the backbone of some fisherman some day. And, ghee whiz! brother - anyone of us might be that lucky guy when the grown-up "little feller" makes the grand snappy fight that arches the rod and switches the line off the reel with a whipping song no other instrument can play. A song that makes the red blood surge through the veins and keys us up to use our finest tackle skill in matching trick for trick the rapid-fire action of the bronze-backed warrior of the watery recesses.

And not only is it necessary to throw back the little fellers, but it is also a fundamental principle that you cannot continue taking away a part of anything without reducing the original quantity. This goes in the fishing game just as strong as anything else, and the fishermen of every community should 
get together and restock their home waters. Nearly every state is willing to furnish fry and fingerlings for the stocking of state waters through their fish and game departments, and it is only necessary to get in touch with these departments to find out just what you can get in the way of stocking material for your waters. The main thing is that the boys have been having fairly good fishing heretofore and have failed to figure that the taking-away stunt, without putting anything back, cannot continue foreverwithout cutting down the supply. Two or three good live wires can get together and organize the "brothers of the angle" in most any locality, appoint committees and get the stocking fry that will put an upkick in the fishing game in their local waters that will keep getting better right along as the restocking goes on each year.

The great herds of buffalo have passed on, the sky is no longer darkened by the flight of the wild pigeons. But, brother, the bass, trout, pike, musky and wall-eye are still with us, for which we are thankful. Let us keep 'em with us, and every last one of us do our part to help them multiply and grow up so that our days on the waters may be long and our quest of the real game fins full o' joy. 


\section{WHAT FOOLS 'EM}

Old-timer, when you sort over your collection of feathery fancies in the fly end of the game do you really think the keen-sighted trout or the wary bass are fooled into believing these same old flies are imitations of the insects they feed on regularly along their home streams?

Take the trout as an example as to keenness of sight. As soon as the fisherman comes into sight along a quiet pool where the trout are feeding these game fins make a quick get-away for the darkened haunt, under log, washed-out bank or rock, but a dog can lope down to the water, lap up a drink, kick around a bit and the trout keep right on feeding. If their sight is such that they can quickly determine between friend and foe, it's a hundred to one shot that they don't take the feathers, as usually tied, for any particular line of feed they have been used to, but probably as a bit of feed that happened to light in their waters.

\section{THE COACHMAN A WONDER}

As an example take the Coachman fly, probably the most used and most generally successful of all trout flies. The Coachman is an imitation of no. 
particular insect that ever hit the water's surface, yet it can be counted on, when flies of all color and variety have been passed up by the brown, rainbow or brook trout. The Coachman was originally doped up from the imagination of one Tom Bosworth, royal coachman for King George IV, William IV and Queen Victoria, and he never tried to make anything like any living insect when he gathered the combination together. This little old white-winged, green-bodied, bewhiskered hook looks like feed to the trout, but not like his regular stuff, and he probably has a fancy to take a shot at it to see how sweet the darned thing tastes anyway.

Which only brings us to the line of thought, old scout, that perhaps a big lot of this stream-side dope on matching the flies you use with the insects that are dropping onto the water, in order to interest the trout, is a piece of unnecessary work. And are you really working the game on the right angle or slipping a trifle out of your course when you cut the corners too fine? Perhaps the answer to some of the empty creels may be in the fact that in trying to copy the natural insect life along the stream, the fisherman has pulled a line of raw imitations that failed to interest the trout, let alone fool them, and if he had used a few of the gaudier and different colored feathers the striking difference and strangeness might have interested many game fins that were too keen sighted to fall for the imitations, but mighty 
anxious to fill the feed-bag with a new variety of juicy feathers.

\section{JIM FEEDS 'EM BEANS}

Which brings us to Jim Boyd, a well-known Chicago fisherman, and a bit of experience he had with the speckled beauties up on the Pike river in northern Wisconsin. Jim had wandered down to the Pike for a little evening fishing, and on the way lost his fly book, but being a versatile chap, he tried 'em out on a dish they had probably never seen before. This bait that filled his creel with some fair-sized beauties was nothing more or less than a couple of baked beans. Jim hooked on one of Heinz' fiftyseven, shot a cast out into the pool, and the way those trout took to beans for a diet sure was worth two bits to see. Just to see how far they would go on the eats, Jim's brother, Bill, who is some fisherman on his own hook, scraped a few fried potatoes, browned to a turn, out of the spider and caught them on this improvised brown hackle and as an especial treat he caught a few on a strip of summer sausage. I'll say that there was enough variety and color to this menu to please any trout, and at the same time it was something they had never seen before in all their trout days, nor did it resemble any of their regular rations. They fell for something different, but James never fooled 'em for a minute that it was their regular evening meal. 


\section{THE HAIR FLY GETS 'EM}

Since the hair fly has been used more on the waters this season it has shown up like "four of a kind" in bringing the game fins to net. Emerson Hough, who would rather fish than work, has doped up the Emerson Hough Bucktail fly, that certainly does not look like any fly at all, but for coaxing the tail kickers into striking, it goes some. The bucktail hairs of this fly tail out behind the hook, and when the fly moves in the water these little old hairs have a wonderfully wiggling move that is enticing to the trout. Of course what they really look like to the fish is another question, but each hair seems to have a nervous wiggle of its own, and the combination of these hairs wiggling in the water seems to be just a bit more than the cautious trout can stand for, so he takes a wallop at this new variety, probably because of the new interest awakened by the invasion of this strange piece of feed - he goes for it before it gets away, as it were.

\section{A FLY WITH A RECORD}

The late Ed. Wyman, one of the classiest fly casters that ever tossed a feathery fancy to the trout and bass outfit, worked up the hair fly tying stunt to an art and his creations with the various hairs and hairs in conjunction with feathers are wonderful fish getters. I know of one of these flies that surely 
never fooled a wily bass into believing it was an imitation of a natural Missouri insect, that took fifty bass from the St. Francis river in Missouri last November and this same fly took 22 bass from the Varner river in the same state in December, and is still in good shape for more of them. Here is a fly, made of hair with a couple of feathers tailing out behind, that simply makes the bass crazy to get at it, yet it looks like nothing that ever flew along the Missouri streams. Is that foolin' 'em or feeding them something that looks good to their eye? You can name it either way, but the fact remains that it gets the fish, which is a pleasant thought to the fellow who goes fishin'. 


\section{TROUT VS. SMALL MOUTH BASS}

There is one little subject in the fishing game that will bring an argument quicker than any other angle of the sport, and that is the relative gameness of the bronzed-backed old warrior, the small-mouth bass and the fast-fighting trout family. To start a real family row, one of those sociable friendly affairs, one needs to but open up on either side of the question among a bunch of the boys who answer the lure of lake and stream. Things immediately perk up and the gang divides into two groups with their shootin' irons well to the front. And by their favorite fighting game fish each will swear by all the gods of the outdoors - for, do they not tingle with joy at memories of water battles of the past in which the game fin they champion did his keenest to stay sovereign of his home waters?

During the past year or so many letters have come in with the query, "Which do you consider the gamer, the bass or the trout?" and right this day two letters ambled in from the same city with the same old stuff. Probably the writers, "K. S. N." and "F. D.," have had an argument on this endless dispute and, if so, here goes for my personal opinion, 
based on my own experiences with the game fins. Polish up your pens, boys.

The small-mouth bass caught with the flyrod in a running stream I consider puts up the gamest fight of the water warriors. Following the game old bronze-backer close, indeed, very close, comes the rainbow trout, then the brown trout, and, finally, the brook trout. The small-mouth puts up a more scientific fight than the trout, and he makes use of more tricks in his effort to slip the hook. He is a greater leaper than any of the trout, which makes him a more spectacular fighter. I have had a hooked small-mouth bass leap eight times; in fact, almost every small-mouth I have hooked has leaped at least once. I have had a rainbow trout leap five times, and the brown trout leap four times, while the greatest number of jumps to the credit of the speckled beauty is two times, and that to a little ten-incher. The general get-away effort of the speckled trout is down and along, back and forth in deeper water, without much effort to clear the surface. It is in the rare cases that the speckled trout makes the up-inthe-air leap.

For a rollicking good fight with a bunch of acrobatics thrown in, give me the small-mouth bass, the stream-raised youngster about two to three pounds and via the light fly-rod route. He has the spots licked off the daintier speckled trout, the roughneck brown trout, and just slips in ahead of the fast- 
fighting rainbow trout. The bass is a lowly cuss, not at all in a class with the trouts for looks and shape, but for dogged courage and pugnacity I hand him the Cross of the Water Trails with six palms.

However, to be perfectly square with the trout family, and the boys around this campfire who are for 'em first, last, and all the time, I think that the trouts are more persistent in attack than the smallmouth. I have known the small-mouth to strike a fly the second time, while I recall a number of times when the trout have repeatedly made a fierce strike at the fly, attacking as often as six or eight times before being hooked, while usually one prick of the hook sends the bass off to other waters.

Taking as a basis of judging fighting qualities and gaminess of the game fish, the resistance, leaping in the air and wily efforts to free themselves from the stinging barbed hook, I place the blue ribbon on the fevered brow of the stream-raised small-mouth bass - for his great little jump on the slack line, his runs across the stream, doubling his back against the current to make it fight for him, his wonderful underwater knowledge of the many snags in his home waters and the many times he gets away through some little trick that he throws just when you least expect it. 


\section{FISHING WEATHER}

Probably way back when Adam sneaked away from his better half and hied himself down to the river in the Garden of Eden, with a can of worms hid behind his back, he looked up at the sky for fishin' signs, sniffed the air like a houn' dog and wet his finger holding it up in the air to get the direction of the wind just to see whether everything was right for fishing. Since that time a big number of his descendants have each season pulled the same stunts hoping to get the fish when they were in the right humor with the right kind of weather to help the game along.

The wind from the east has been blamed for more slim stringers than any other weather condition and there is something to this, by the way, that is on some lakes although it does not apply to all waters. In an east wind it is well to fish off the lee shore while on some lakes that lie without much broad eastern exposure the east wind does not affect the fishing conditions hardly at all. The weather man will tell you that there is usually a lower barometric pressure during an east wind than at any other time; that the atmosphere is heavy during that period. This has been given as a reason for the fish seeming to be 
off the strike during an east wind, yet I would rather fish with an east wind ruffling up the water than with no break to the surface at all.

Fishing on some lakes will fall off with a wind from another direction, caused mostly by the location of the lake and the exposed shore which gives the wind from that particular direction a sweep over the lake which disturbs the feeding grounds and makes the fish seek other feeding places or the deep water for protection, and because the fish cannot be located at the same old places, the local anglers say that particular wind puts them off their feed on those waters, while if the fisherman would keep at the game and locate the places the fish have wandered to he would find them just as eager as before to take a smash at his lure.

I would rather have a light wind breaking the water in small waves anytime than fish when the water is perfectly calm and quiet. When the surface is broken a trifle with just enough wind to keep your boat moving along slowly, then the fishing is usually at its best. This applies particularly to casting for bass, and for muskellunge let me have quite a nice dash to the water with a few waves breaking here and there, for that is the time the old rough fighter likes to swim around feeding on the other fish which have a hard time keeping their sea legs and not much time to look out for the savage old barbarian who is out hunting them. 
The bright sunny day is about the poorest fishing day and this is particularly so in July and August when the hot rays of the sun make the shore waters uncomfortable and the fish go down in the holes for a cooling off. When the day is cloudy, however, one can fish right along and have far more chances of finding the fish at home in their usual haunts than when the sun is burning through one's shirt. In the early and late season, however, the game fish are just as actively on the feed when the sun is out as any other time, and in fact the warmth of the sun brings them to the shallows at that period. They probably realize at the tail end of the season that the warm weather is soon going to fade away and they like to sport around and feed in its warm rays that penetrate into the shallow water, and enjoy life a trifle before the ice sends them way down below for the winter.

Early in the season it takes a few warm days to put the fish in a humor to strike, and from that time on most any kind of a day is fairly good until the warm summer sets in. Even at that, after the first few weeks of the season, after it has opened up right, you will find that the early morning and late afternoon fishing is the best regardless of the condition of the weather.

When the surface of the water is broken by a light wind you will find that the fish do not see quite as clearly or quickly as when the water is still and for 
that reason the lighter colored lures are the best, and the pork rind or natural bait will be more effective if a spoon or spinner is used. On the dark cloudy days the white artificial is very effective and the nickel or silver spoons better than those of the duller copper or brass.

Just because it happens to rain is no reason why the fisherman should row to shore and hunt up a cozy place under a protecting tree. Slip on a rain cape and keep on a-fishing, for many of the biggest ones have come right up into the boat when J. Pluvius was busy tipping over the rain cans. And after the rain, oh boy! That's when fishing is just right off the pan. Then is the time to play the shore line with the fly, either the fly of the fly-caster or the weighted bass fly of the bait-caster, and for the simple reason that many of the winged insects have been beaten down on the shoreward surface and the bass know this from former rains. This brings them in to feed on these choice titbits and the fellow who drifts along casting in towards the shore line has a mighty fine chance of bringing up his percentage in the fishing game.

Looking the whole weather dope over we find that a fellow can generally get fish at any time of the day and under any weather conditions, but he must fish according to where the fish are at certain times during the day and kind of weather. On the 


\section{FISHING WEATHER I8I}

hot day during the mid-day period it would be foolish to waste time casting the plug or artificials but if taking a chance at still fishing the live bait down deep in the holes would get them. 


\section{COLORS OF ARTIFICIALS}

What color makes the bass fighting mad and the musky turn in a savage swirl to strike with a smashing snap of his sharp-toothed jaws? As a usual thing, taking into consideration lake and stream waters in general and averaging the proposition from many reports, we find the white artificial with a little red the leading combination that makes the game fish come through with the fighting strike. This is particularly so in the early season when the bass are in the shallows and later it is best used on the day that is cloudy and overcast, while at the end of the season when the fish are again feeding in the shallows it works well any time in the day.

The next best bet in the color line from past experience of a big bunch of anglers seems to be the green and white combination, usually a crackled green back and a white belly. This combination, somewhat on the froggish hue, is very good as a lure for bass and the larger fellows in the pike and muskellunge families. And as an underwater lure for the deep feeding wall-eye pike this color goes second to none as a sure enough wall-eye enticer; while right in among the weeds and lily pads for the 


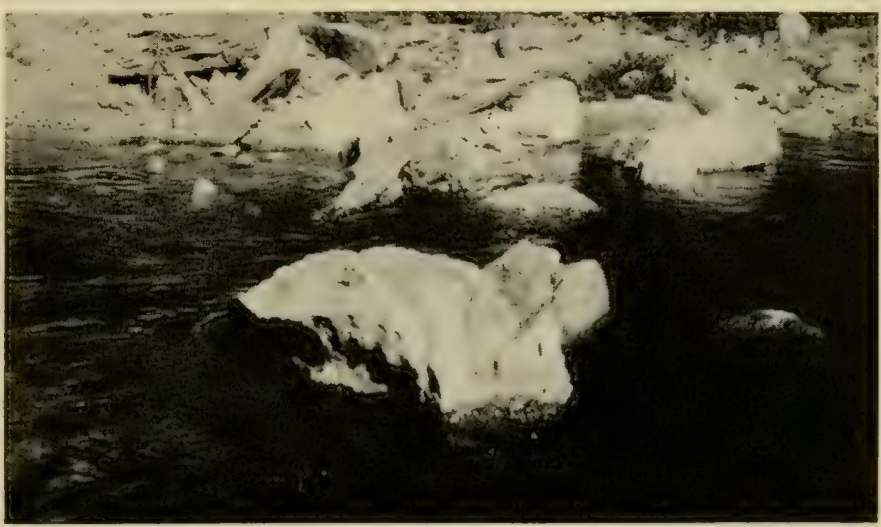

Casting our fly so that it dropped on the water above this rock brought a nice strike as the fly floated down in the little swirl $0^{\circ}$ water below and a ten-inch rainbow trout landed in the creel. In that little nook he laid waiting for everything that floated into sight.

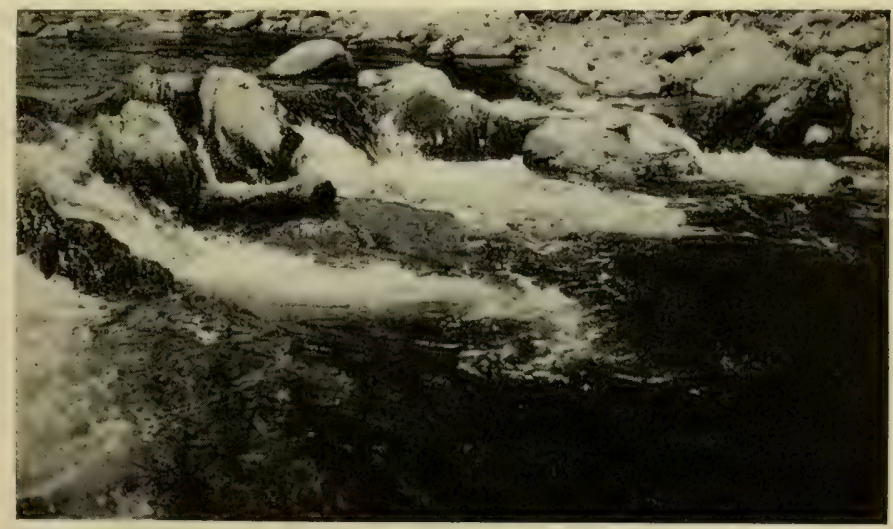

In the pool below this small falling water we landed some nice trout. letting the fly float from the rougher water into the swirls of the pool. The same use of the floating bass bug would be made in bass waters. 

bass or pike it often gets the strike when other colors fail.

The consensus of opinion as to the next color places the laurels on the rainbow effect and the perch imitation. These colors shine on the bright sunshiny day particularly, as the glaring flash of the all-white lure is too much for the fish on a day of this kind and the darker color of the rainbow and perch lures appears more natural. The use of these colors should not be confined to the bright day, as many game fish will be taken at times in any kind of weather.

But even with all this dope, some condition of water or weather, or perhaps simply an epidemic of indigestion or liver trouble on the part of the fish in a certain lake may throw this schedule of colors into the asheap and reverse English must be put on the list, starting the successful color or combination from the rear end and winding up with the white and red.

Take, as an example, a lake I fished last season the first two weeks in July. At this time the only color that seemed to be of any value was the white, with a dash of red. The fish simply turned up their noses at all the other colors, but they certainly did go for the white surface plug. There were just two white lures among the three of us fishing this lake, and you can gamble a few beans that they were fairly popular; in fact, it was a case of grab for them all the 
time. And the way these plugs were mauled by the big fighters, both bass and great northern pike, of this lake soon cleaned the enamel off.

On going up to this lake this season with the same pals, we all stocked up with a variety of whites in all shapes and sizes. The trip was made the second week this season, and great were the expectations of wonderful catches with these wobbling white affairs. We cast that lake to a finish for two days and not a strike on the whites - not ever a ripple except those made by the lure as it hit the surface. I happened to have a varied assortment of other lures along and put on one finished with the new scale finish in imitation of the chub. Casting this bait into water that had been whipped almost to a foam, figuratively speakin', with the white lures, I drew a strike on the first cast, and of all the colors cast on that lake in ten days the scale finish was the only one that had sufficient fish to its credit to keep track of. Over 95 per cent of the fish were taken with the natural scale finish; the balance with the other darker lures.

The only explanation that I can make for this is the fact that the fish were more on the feed at this lake in June of this season and that they struck the lures because they were after a feed, while probably a little later in July the game fish would be striking more through the fighting instinct, at which time the white and red would make them fighting mad 
and scrappy. It is interesting to note also that the pike took to the live frog with a wallop and were eager to strike at it, but the frog-colored lures never got a peep out of them.

I have a letter from Watts Richmond, a wellknown angler who has wet his line many times from coast to coast, that was written from Butternut Lake at Three Lakes, Wis. (waters that are famous for their small-mouth bass), and Watts passes out the information that he has had remarkable luck with the yellow surface lure with paddle spinners. This lure is a blunt-shaped minnow with paddle spinners that revolve with the head, and it rides the surface at all times, throwing up quite a riffle to both sides as it is reeled in. The body color of the lure is a light yellow - sort of a canary color - and it is spotted all over with gold spots.

This lure is colored after the old style aluminum lure used so much a number of years ago in the Eastern states for bass and called the Yellow Kid, probably because the spinners resembled the ears of that well-known comic of a few years back. Here is a color combination that has not been used much in this neck of the woods, the mid-West; something that one of the well-known anglers has been making a killing with, though few plug casters carry anything odd in the color line in their kit. That it was a success is shown by the fact that I had a halfdozen hurry-up calls from fellows up at Butternut 
to send them a few of this style lure. And it was some job locating them, there having been practically no call for this color, and it was mostly out of stock.

Just as a safety first, it might be well to include a few of these odd colors in the kit and have them laying away for emergency use. 


\section{LARGE-MOUTH VS. SMALL-MOUTH}

It seems that every kind of game fish has its loyal bunch of boosters, who praise their special pet fish to the sky and cuss out most every other species. Many fellows sing the praise of the brook trout, the rainbow and the brown, but the dyed-in-the-wool small mouth basser does his salaams to the red-eyed bronze-backed warrior of the running stream and to no other flirting game fish.

Right at the start, let me say that I am for the small-mouth, because he is the scrappiest game fish of the inland waters; he can kick up more of a rustling fight for his size than any other fish, and he just loves the scrap; fact is, although he is purely an American fish, I have my suspicions that he has a streak of Irish in his make-up. He dotes on giving you the slip right up to when you are about to net him, and he can blarney you into giving a little slack so that he can hit the surface and throw your hook with a massive shake of his body.

Although I am for the small-mouth as the scrappiest fighter, this does not lower the large-mouth bass as a fighter in my estimation. The large-mouth, as a general rule, may not be quite as fast and clever I 87 
as the running stream, small-mouth, but oh, boy! I can get a lot of joy out of having one of them strike my bait and take it for a run. And let me say that you don't land every large-mouth you hook, not by a jugful. The large-mouth is a clever fighter and a strong one, and he strikes for the air just as much as the small-mouth.

The small-mouth bass is more inclined to life in the streams. He likes the running water, the clear, cool stretches and his fighting the current all his life makes him a strong, sturdy scrapper. His fins and tail are well developed from fighting fast water, and when you hook him you naturally get the benefit of the muscle. And he is clever in that he knows every snag and root under water, where he goes rapidly in an effort to snag the line and tear it, or he may quickly make up his mind to cut it across the sharp edge of a rock and speed off to other localities. He knows the stretch of waters he swims about, and usually he has some particular location that he calls home, and this under-water home is as familiar to him as the city dweller's flat. This naturally gives him an advantage and he is quick to take the benefit of it.

The large-mouth is usually found in the lakes. He has no particular love for the streams, although he is often found in them. But his popular dish is the lake where an abundance of weeds, reeds and lily pads grow, and this is his real home. Where 
there are good weed formations in any lake is a good place to cast for the large-mouth, and a snag, windfall, log or brush-heap is generally the hiding place of a good, big large-mouth, who grows fat and lazy, snapping up the unwary pan fish and minnows that swim past his hangout. That is what makes him the big fellow we all have the hankering for.

Often we find the large-mouth and small-mouth bass in the same lakes, the small-mouth making his home around the rocky ledges, off the sand-bars, the shoals and the gravelly shores and in the warm, midsummer days down around the spring holes; the large-mouth hunting the mud and marl bottoms, the underwater weeds and the lily pads. About the only time we find these two bass friendly-like is in the hot days when both of them school around the spring holes. This is not always a set rule, however, but it is the case in the majority of lakes where two bass live, as I have caught both large and smallmouth bass in some lakes in the same locations and at the same time. I recall one instance where a pal caught a fairly large small-mouth casting from one side of the boat, and I was lucky enough to land a fine large-mouth from the opposite side. My largemouth of that cove put up a fight equal to the scrap of the partner's small-mouth, and it stands to reason that these fish living in the same waters should fight about equally, anyway.

The large small-mouth will fall for the wooden 
minnow the same as his cousin, the large-mouth, but it is fairly hard to interest him in the plug in stream fishing, except the smaller sized artificials. In fact, I have found the pork rind with a small spinner and a red ibis fly about as attractive a bait as you will find for him in the stream fishing. Of course, to get the real sport out of fishing for the small-mouth the fly-casting game has the rest of the outfit licked at the starting post, as there is nothing that quite equals the fight of a small-mouth on the off-end of a long, limber fly rod. And he is quite eager to strike the fly after the bugs, millers, butterflies and grasshoppers have come forth to taunt him by flying close over the surface of the water.

The safest bet in going after him with the fly is to have an outfit a trifle heavier than your trout flycasting tackle, as he puts up a rough fight which calls for some roughing on your part, something that a rather light trouting rod will not stand for and come out of the battle without a kink in the tip or one of the joints. The wet or sunken fly will probably interest him more than the dry fly in most cases, although a floating bass bug placed in the right spot will make him curl up in delight at the chance to strike it.

The large-mouth bass of the lake is a trifle hard to interest in the fly. There are times after a rain when the fly can be played to a finish along the shores and the large-mouth be taken with apparent ease by 


\section{LARGE-MOUTH VS. SMALL-MOUTH I9I}

this method, as instinct has taught him that the surface at that time is usually filled with good, juicy feed in the shape of insects beaten into the water from the trees and brush along the shore. 


\section{AMONG THE LITTLE FELLOWS}

- There is hardly a fisherman in the gang who cannot help slip back in memory to the beginning of the fishing days with him when as a kid he wiggled his toes in the clay or sandy banks of the home creek and kicked along down to the favorite hole to take a flier at fishin' for the sunnies, crappies, bluegills, rock bass and perch. Those were some days and great was the joy when you trudged home with a heavy string of those snappy little fighters. Your tackle as a whole didn't amount to much as tackle goes nowadays, probably a pole cut from the nearby bank, a stretch of string and a penny's worth of minnow hooks, but, oh boy! how the little fellows came up and nibbled the worm. Then you just naturally yanked them out of the water, way up onto the bank among the grass and weeds. They never had a chance after they took your bait and matched wits with your husky arm.

It's different now. You go up North after the big musky or the scrapping small-mouth and his bigmouthed cousin, both husky fighters of bass fame, and you have sort of forgotten all about the antirace suicide bunch, the pan-fish. Some day when 192 
the bass are off the feed and the pike outfit just will not notice anything you toss them, take a flier at the pan-fish and have an afternoon's real fun.

To get real pleasure out of fishing for the panfish and put it on a sporting basis, slip into a tackle shop and buy a long steel still-fishing rod about ten or twelve feet long. This is a light, whippy rod that a little pan-fish can bend to considerable arch, and it gives them a fighting chance to get away, something they do not have with a short rod.

Probably a lot of the fishing gang will shout right out: "Huh! What sport is there in landing a panfish?" From my end of the table I'll slip a stack of chips that a lot of regular guys at the angling handicap will not land every pannie they hook, and that when the long rod begins to arch and the line cuts the water in short little zips, they will realize that they have been overlooking a part of the game that is worth while.

Naturally, these little rascals do not put up the screaming fight of the gamer basses and pike, but they do make a short, decided effort to stay in their home waters, and, finding the give to the rod, they are quick to take advantage of it.

The rest of the outfit can be the bait-casting reel, an old line with a three-foot gut leader and a few very small Aberdeen or Sneck hooks, not to forget split shot sinkers and a bobber, if you wish it. The gut leader is preferable to simple snelled hooks, be- 
cause it will keep your line upright in the water, which is a decided advantage when you are still-fishing. With this outfit, and the knowledge that the pan-fish are rather accommodating little fellows, biting any time in the day and most any time during the season, you ought to hook out a lot of sport giving them the once over.

The crappie is found in most of the lakes and ponds as well as the more sluggish streams, and although you can get them all through the season, during June and the fall months they are at their best. Worms, live minnows and grasshoppers make a good bait, and at times they come right up to the small trout flies. The rock bass is a trifle more particular about his watery quarters, having a preference for the clear, cold water of the running stream. Here he likes to stick around among the rocks, in the deep holes or around the stumps and brush heaps or windfalls. In the lakes he is likely found where the pickerel grasses and reeds grow, while an old water-soaked log makes a real home for him. About the best baits are worms, minnows and grub-worms, while a small spinner often makes the bait more attractive. Keep it moving a trifle in the water, and look out for a scrap at the start that will make you think you have a larger fish, as he starts out with a rushing fight when first hooked, and then makes another short splurge when brought up to the boat- 
side. At times in the evening the rock bass is a consistent surface feeder, making good sport on the fly rod. I have found that he takes the red Ibis, Parmancheene Belle, the Silver Doctor flies quite freely, and when the small yellow butterflies are on wing and hitting the surface every now and then, the smallsized Yellow Sally fly is a rather taking one.

The bluegill is probably more numerous than the other pan-fish, and is found in nearly all lakes and quiet streams, the smaller lakes being usually more heavily populated with them. The bluegill runs to good size as the pan-fish go, and is, I believe, the gamest of the outfit. He schools off the edges of the sand bars, in among the weeds, and you can locate a crowd of them and land the whole outfit without moving the boat. The bluegill hooks himself as a rule, nibbling slowly at your bait until he has sucked in the bait and hook. Finding that he has hooked himself, he gets a little sore, and the show opens with the bluegill making tracks for somewhere else. Any of the baits that interest the other pannies make the bluegill happy, while small pieces of cut-up fish gullet or belly are quite good for him.

The entire pan-fish family are an interesting bunch of little fellows that make fishing worth while on the days when the rough game fighters are a trifle quiet and not over friendly, and they are accommodating enough to bite any time. Because of this 
and the fact that there is nothing better in the food line than a platter of well-browned pan-fish, a sweettasting fish, because of the clean living of the tribe, we can thank them and toss them a little credit, just as well as any of the game fish. 


\section{CANOEING THE UPPER WISCONSIN}

Have you ever pushed a canoe into the water at a little by-station on a railroad in the north woods and paddled off into the wilderness, with your grub pack and kit the only thing between you and existence for a week or two?

If you have never tried this little stunt, old-timer, you have slipped up on the real sport of the fishing game. A fast-running stream, with a bit of white water here and there; the camps in the evening, the "free-from-all" feeling away from the walled-up cities builded by man, just a sneak back to the instincts of our forebears in their wilderness conquering days. It's great! It'll put a pinch of pep into your system, smooth down the raveled ends of your nerves and give you an appetite that will cost you a fortune to satiate when you get back to the grind of everyday life.

There is a canoe-fishing trip that I take every year, regardless of any other, and that is on the headwaters of the great old Wisconsin River. A trip from Conover, Wis., a little drop-off station on the Chicago and Northwestern Railway, right in the heart of the woods. Nothing there but a depot, a 
store and a house, but when you slip the canoe into the water where the stream is only about thirty feet wide you begin a trip downstream that will end up at Rhinelander, where the river starts out into the regular-size class.

This trip can be made with easy paddling in six days, taking plenty of time to fish or it can be made a two weeks' trip by loafing along at a nice easy run with the current and putting in more time swinging the rod. The fishing is excellent all the way from Eagle River down to Rhinelander. The bass fishing in the waters below Rainbow Rapids is fine, and from the concrete bridge, three miles below the Rainbow, you will find no better river fishing in Wisconsin.

Five miles below the concrete bridge the river widens out into a lake formation and the backwater sloughs here are alive with bass, musky and pike; in fact, the river from the bridge down to Rhinelander is a fine stretch of musky fishing. In this run of water last season a fifty-two pound musky came to gaff, and quite a number of old huskies in the thirty-pound class, which is some fishing when you consider the added kick tied up in the tail of a riverraised musky. Although you will find good fishing all along the river, the most time should be devoted to fishing this piece of water.

On the trip you will have to carry your camping kit and grub for a week at least, as you will find no 


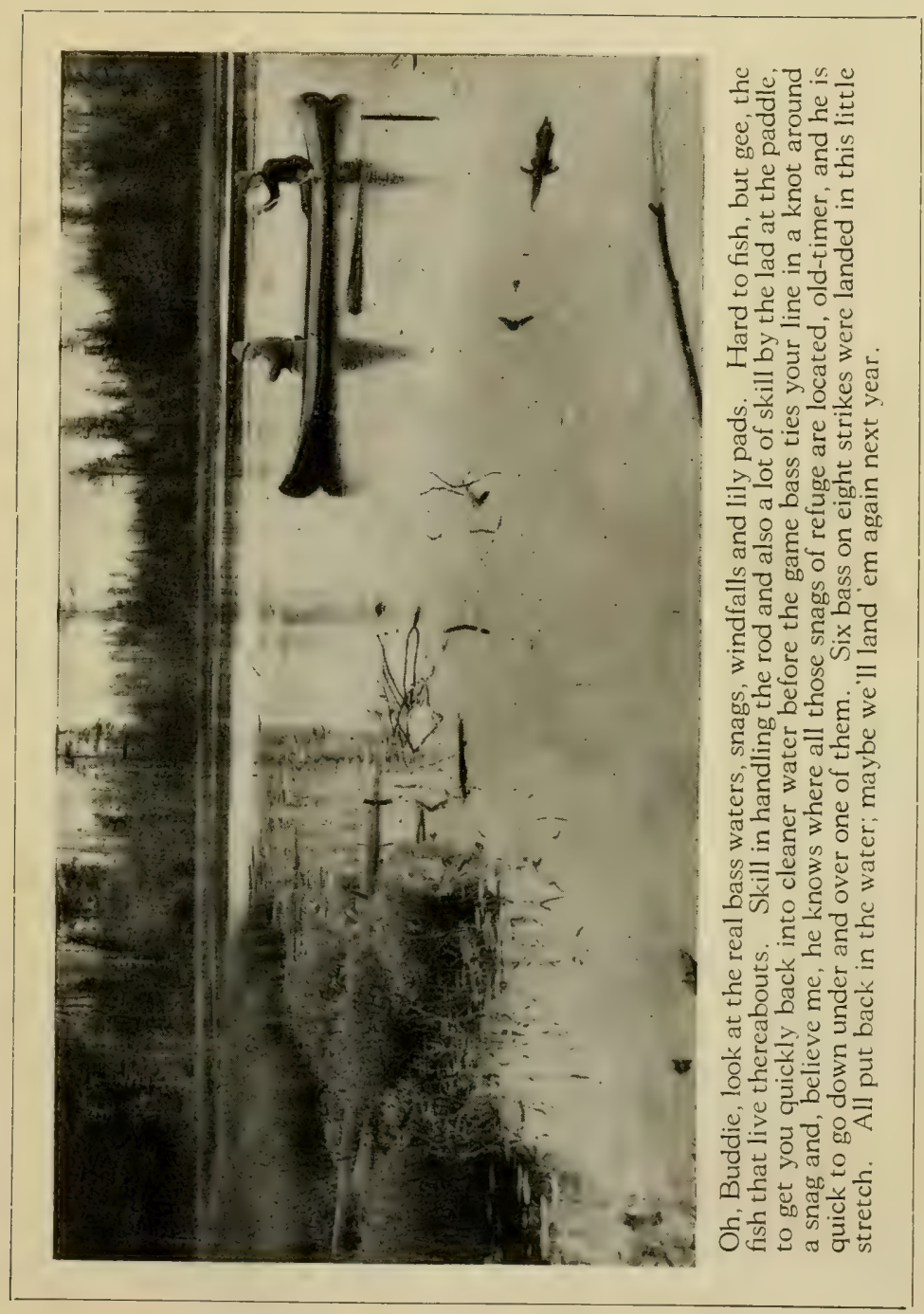



place to stock up after leaving Eagle River until you strike the Frenchman's, about three miles below Rainbow Rapids. Here you can get enough vegetables at a moderate cost to carry you through the rest of the trip, although you will pass farms here and there all the way to Rhinelander from the Frenchman's down. But he is a good old scout, and you can make a dicker with him for everything in the garden line, also eggs, butter and chickens.

The first day you will make about thirty miles, starting about 8 o'clock from Conover, and pulling into the high bank to make camp about 4 P. M. the first day in order to practice up on making camp and cooking over the camp fire.

About two miles below camp you will pass a red wagon bridge and near by a farm house, where you can fill your water bottle at an excellent spring. Four miles further is the Eagle River power plant dam. The churning of the water will be heard some distance, but cheer up, old scout, you cannot ride the dam.

The first and only portage is now in order, but it is merely a short hike of a hundred feet around the dam to the river below. Here the rocks stick out of the water and the speed of the stream increases, but it is easy stuff to run and no chance of a spill unless you hit a submerged rock, and a spill here is not at all dangerous.

After a run of about a mile farther you hear the 
rumble of Otter Rapids; it sounds like a bit of faroff thunder, but as you close in on the fast water the rumble and roar become louder.

For two miles from the farmhouse you will have a stretch of riffles and fast water that is real sport dodging the rocks and keeping the canoe in the channel. Keep your eyes peeled for a low bridge of wired logs stretched across the river about three feet above the water. Here you can make camp on the left-hand bank about 300 yards above the bridge, where there is a good spring.

The third and fourth day can be made in easy stages of running and fishing. The small-mouth bass fishing along this stretch is fine. Along about noon the fourth day you will get the first purring sound of the Rainbow Rapids, and as you hear them you will see from the water whirling and foaming over the rocks that this is the fastest and roughest water of the entire trip.

They'll throw a scare into you, at first, so pull into shore and look 'em over before shooting them. If you prefer you can portage here, making a short carry of about 600 yards, but the rocks are nearly all below the surface and the running is safe. Slip the little old canoe into high and the ride between the cliffs of Rainbow will give you a bunch of thrills that will make you feel like portaging the canoe upstream and hitting them down again. 


\section{LEAVES FROM AN ANGLER'S DIARY}

A WEEK ON WISCONSIN WATERS

Three Lakes, Wis. - It takes all kinds of people to make this world the grand old place it is to live in and likewise it takes all kinds of people to make up the fishing clan. It sure was a mixed group holding down the cushions in the Pullman smoker on the way north to the home of the game-fins among the thousands of lakes of upper Wisconsin.

Discoursing on the best bait for the early morning stunt was the secretary of one of the great west coast railways, and his pal of the smoking-room, who made a specialty of casting with the floating bass bug, was a doctor of note who knows more about the nose and throat than most fellows know of their favorite brand.

Mixed here and there in the keen-eyed crowd was a wholesale grocer and his star traveler, a druggist from a down-state town, and his best friend, the local horse doctor, a preacher, and a city-hall chair-warmer and myself, sitting back and sawing wood.

It sure must be a great call made by the lake and stream gods to drag men of all professions and work 
from their every-day life, and it certainly registers strong, because these same fellows hit the steel each year to add to their records of game battles well won and sometimes, as they will admit if you have the goods on them, lost.

And ragged and worn from the driving work of putting the shoulder to the wheel and speeding things along to keep production up, this band of workers comes back from the trip to the big woods country full o' pep and with a clear brain.

That the call is widespread and the rod wielders come to these famous-waters from the far edges of this great old country is shown by "shooting the lamps" over a few registers at the different resorts and camps. Here at Three Lakes I found them from Boston, Buffalo, Newport News, and Pittsburgh on the east; Mobile, Houston, Memphis, and Jacksonville on the south, and St. Louis, Omaha, Wichita, and Oklahoma City on the west, with a big scattering from towns we do not know by their first names.

Hitting the long trail to the late Shorty Fournier's camp on Butternut lake through twenty miles of timber from Three Lakes gives you an awful appetite for breakfast, but, say, old-timer, the smallmouth bass fishing in Butternut and nearby lakes is as fine as you will find anywhere.

Al Shotwell, of Chicago, landed seven smallmouth that went over four pounds yesterday, which, 
by the way, we might say is some fishin'. H. A. Steinwender, of St. Louis, brought in as fine a string as you'll see in many a day's fishing and his wife flashed a couple of three and four pounders that showed the gallantry of the Butternut small-mouth bass, but then what fish could resist striking the lure of a charming lady in khaki.

Watts Richmond, of Buffalo, who has tossed his line in the waters from coast to coast and who knows most fish by their pet names, gets them via the fly route, and they certainly must like his flies because he makes the big ones come up to the surface right along. Watts' opinion of these bass waters is shown by the fact that he came up last season to stick around a couple of weeks, and he stuck right on the job for five months with a comeback on the openers this season and still here.

On the back trail we run in at the Laurelton resort, over which Mrs. Drake presides and tacked up to Mrs. Drake's rod is a forty-three pound musky. Do you get that, fellows, a forty-three pounder, and just a slip of a woman handles the rod with the skill necessary to make it say "uncle"? This game-fin struck on a No. 9 Skinner spoon, and the rod used was a light Bristol No. 25, with a fifteen-pound testline. Some light stuff to rough-house a forty-three pounder. One hour he pulled every musky trick he had learned from the old fathers of the tribe and what new ones his own keen mind had doped out. 
Four times he hit the air, then under the boat and circled it with a corkscrew turn and a head-rush for a long dive. But he came to gaff, and this musky is probably high fish now on record for the lady anglers.

F. C. Binckley, of Sycamore, Ill., pulled out an eighteen-pounder from Little Fork Lake just to show me how they were hitting it that day, and Charles C. Burton, of Edwardsville, Ill., and C. F. Johnson, of New Smyrna, Fla., brought in fine strings of bass and wall-eyed pike to show what Laurelton folks could do if they really wanted to.

Eagle River, Wis.-Up in these famous musky waters there is one big old granddaddy musky that will never answer to the twirling flash of the golden spoon as it glides invitingly through the deep green waters of Meta Lake. This sire of many muskies passed on to musky heaven in the quiet waters of Meta Lake, probably surrounded by the whole tribe; at least, while fishing a stretch of the south shore of the lake with Horace Tilden we found him floating, white side up, the waves kissing him tenderly as they washed him shorewards.

There is a bit of a story connected with this big fellow, who topped the scales at fifty-eight pounds, had a length of fifty-five inches and a girth of twentythree inches, to say nothing of a mouth that looked like a coal scuttle and armed with a double row of dagger-pointed teeth that spoke well of his ability 
to forage enough to eat among other roughnecks of the weed-beds. When we hauled this old-timer ashore and gave him the close-up we found a bulletmark close behind the gill covers. It was entirely healed over and this bullet probably helped the old fellow to his last swimming-place.

But to the story. Early in June, B. D. Hoornbeek, of Elgin, Ill., who had been fishing out of Tilden Brothers' resort, on Lake Meta, hooked and fought for over an hour a large musky, and, after bringing him close to the boat, he took a shot at him with his automatic, hitting the musky behind the gills. This sort of livened the big one up and in the final effort for freedom and the right to kick around the cool waters of Meta he snapped the line on Hoornbeek and did the fadeaway.

The big fight was witnessed from the shore and it was a disgusted angler who told the story that evening before the big log fire. Having had a taste of the fighting power of this gray-whiskered father of the Meta muskies, Hoornbeek stuck around four more weeks and spent the entire time trying to beguile this self-same battler to take his LoweStar Spoon with its gold and silver sides, figuring that he had liked it so well the first time he probably would take it again. Although he succeeded in landing a number of other muskies, the big one was trying to get back his kick down in some cool hole far from any lure. The bullet, however, probably 
worked its evil spell and no other fisherman will ever feel the thrilling fight of this wily barbarian. For his hour's fight we give him credit. May he kick around happily in the musky waters over the great divide.

Fishing has been good at Meta and the other lakes fished by the anglers at Tilden Brothers' resort, the bass and pike playing the game friendly like with the musky coming in when coaxed a bit. Alfred M. Lane, of St. Louis, had a nice string of bass the day I tricked a four and a half pounder into the landing net. H. E. Holbrook, of Boston, brought in a fine string of bass and pike, the largest wall-eye a five pounder. I'm betting a stack of white chips that Holbrook feels right at home with the Tilden boys, who were originally from Boston; that was away back when I was a kid, because we had as nice a pot of real Yankee Boston baked beans as any Bostonian ever caressed with a fork. Great beans, great fishin'! What more could a fisherman want in a day's paddle?

Meeting Sheriff George Jackson, of Vilas County, on the main street of Eagle River, not officially, of course, "fellers," but just accidentally, I "flivvered " down to Lake Alma, where Mrs. George has the Red Oak resort and put in a day's fine fishing on Alma, Little St. Germain, and Moon lakes.

The bass were particularly interested in a PfluegerSurprise Minnow that I tossed in among the weed 
pockets; luck was with me and the bass in these lakes, which probably accounts for the fact that I had as nice a bit of fishing as I have met up with this season.

E. C. Woods, of Milwaukee, brought in a bass limit the same day from Little St. Germain and took 'em home with him, and Colonel Andrews landed a seven-pound pike as well as a fine string of bass in the same waters. Fishing with a sheriff is a great game, especially when he is a corking good fellow like George Jackson and everything you are doing is within the law. That the game and fish laws are respected in Vilas County as well as the regular line of laws that are necessary for other fellows than anglers is no doubt largely due to the fact that little old George Jackson is on the job. I'd rather have him with me than "after" me. He's one of those medium built fellows who don't say much, but one squint at his eyes gives you the dope that he gets what and who he goes after.

There are days, of course, when the fishing is off. That is a natural thing: days when you can toss 'em any old feed or bait and they don't even nose it, but any fellow but a game-hog expects such days and can find many delightful ways to pass the time in the north woods when the fish happen to be off their feed. Then, again, there is a lot of locating the fish in any waters if you expect to land these gay tailkickers. Often a fellow will waste his time fishing 
a stretch of water that no self-respecting game-fish would inhabit. Waters that have no feed have no attraction to the game fish that thinks of a feed above all else. You've got to locate 'em to fill the creel or stringer, and the best way is to have a guide or study the waters yourself that you intend to fish.

Arthur Guy Empey, famous as a Hun strafer with the British Tommy before the U. S. kicked into the big scrap, later famous as the author of "Over the Top," has slipped back to the primitive and is strafing the bass and musky up in great old Eagle River waters. There is confusion in the fish families and warnings have been given to all the big fins that this short live wire is on the job and after them.

Like anything else that Empey has tackled, he has kicked into the fishing game with both feet, and yesterday he landed five small-mouth, red-eye bass weighing $4 \frac{1}{2}$ to $53 / 4$ pounds, not counting a bunch of smaller "feelers" he put back in the Eagle River waters to grow up. In this respect Empey is a sure enough clean sportsman, as he returns many fish to the water.

In the meantime, fellows, don't those old "hewop " bass sound good, and can you slip back into your easy-chair and dope up the rattling good fight they put up, four or five pounds of high-volted kick in every one of them. The sing of the line as they made their rushing run for a snag or windfall, then the back rush on the line to get a bit of slack. The 
frantic speedy reeling in to take away the slack as the game-fin made his wonderful break on top o' the water for the massive shake of his whole body in order to throw the stinging hook. Then the giving of just a little line as he fell back on the water so that he would not land on a taut line and tear the hook from his mouth. And finally as his runs shortened and his kick lost its pep, slipping the landing net under him and there in the boat is a bronze-backed warrior, as keen a battler as ever fell to the skill of a fisherman. Man, that's the life, full o' thrills from the strike to the landing-net, and never once sure of your fish until you have him on the stringer.

Captain Empey is making his headquarters at Tilden Brothers' resort on Lake Meta, the same old lake from which we dragged the 58-pound musky. Horace Tilden has been showing Empey the high spots in the fishing-game in the Eagle River waters, and by the way, Horace knows just where these spots are, as he has been kicking around the lakes and streams in the vicinity of Lake Meta for twenty years, and he sure has a close acquaintance with the real "holes" of that part of Vilas County. After hearing the dope on the 58-pounder, Guy made up his mind to stick around the waters until he connects up with the walloping kick of one of these oldtime residents of Meta or one of the other famous musky lakes nearby, and as he generally gets what he goes after, I am playing it right across the board 
that he lands one of these husky roughnecks before he gets through. And by all of the points of the game, he should; the musky are there and Empey has shown by his bassing work that he is no mean angler at that. Fact is, he plays the game fins skillfully and with good judgment.

I sure feel sorry for the musky of the Eagle River waters. That Empey certainly has his mind on the game, and with Horace Tilden hunting out their hiding-places, the musky has no chance a-tall. The big one might just as well follow the dope of the coon with ol' Davy Crockett and come right up and hook himself on Guy's lure and be done with it. That pair are going to stick to the musky game if it takes a year, and when I recall that a forty-pounder two seasons ago fell to the lure of Mrs. Molden, of Chicago, from these same waters, here's crossing my fingers with the wish that Empey gets a chance to hook up with a real old roughneck and test his tackle skill against the wily cunning of a musky with a tailful of tricks he has acquired himself and what he learned from the other gray-whiskered musky of the under-water trails.

Phelps, Wis._- "There he goes!" piped Dick Menefee at the steering-wheel, as a big fine buck jumped on to the road and speeded in front of our Henry the Fourth on our way to Long Lake, where Charley Hazen holds forth at the Long Lake Lodge. That word had arrived at Eagle River that the wall- 
eyed pike were " hitting 'em" up at Long Lake, so we decided to take the cast at some of the big relatives of the past performing wall-eyes of that deep, cold lake, which, by the way, is the real home of the wall-eye pike.

As a big buck made his getaway down the road between the walls of hardwood timber, four trigger fingers gave a nervous twitch and with a fanning wave of the tail Sir Buck hopped into the green. This was the sixth buck that we had jumped on the eighteen-mile drive to Long Lake, which sure makes the old buck law look good to the deer-hunter. Last season a bunch of antisportsmen had enough influence to have this law set aside and many doe were knocked over by a bunch of near deer-hunters who were too lazy to go after a buck.

Not only was the buck law a protection for the doe and a means to increase the deer of Wisconsin, but it also was a fine protection for the hunter, for the simple reason that another hunter never shot at his deer until he had a clear enough view of the game to see the horns. This fact saved many lives, as the inexperienced hunter generally banged away at any movement in the brush or at what he thought might be a deer, with the result that the casualty list from the north woods ran high and the deer got the habit of sticking to the tamarack-swamps during the day time and feeding at night while the season was open. With the one-buck law off the statutes for keeps 
there is not a big enough spread of horns in the north woods country to get me into the timber dressed in a suit of khaki hunting-togs. And as far as wearing a fur hunting-cap, nix, that's too clean a target for the over-anxious pot-hunter. It might have been all right for ol' Dan'l Boone to skip around through the woods with a coonskin hunting-cap, but in his day they never shot until they knew what they were shooting at.

The last few miles on the way to Long Lake run through virgin hardwood, and the deep dark forests of green with the sun-shafts filtering through in golden spots are a wonderful sight for the city man, whose eyes are dimmed by the backfire of the sun from the brick walled cities builded by man, not to mention the eye-strain caused by the gay broiler as she trips the light fantastic while he guides his fork through the midnight supper. And nerves, why a couple of days in the hardwood country make you forget you ever had any, especially if you spend the in-between days on the lakes or streams coaxing the big boys up to the surface.

We hit Long Lake Lodge and the glad hand of Charley Hazen just in time to see Elmer Patton come ashore with a twenty-six pound musky that had put up a twenty-eight minute fight that was a nervetingler. Up out of the water five times in a rattling good leap, with a shake of the body each time that rattled the No. 2 Lowe-Star spoon like the tattoo of 
an impatient telephone. Back on the line after the third rise, with a straight run for the boat and a header under it, and Patton had his work cut out for him for a few minutes to keep the wise old musky from corkscrewing back on the line and getting a purchase hold for his tail so that he could break it.

The day before Neic Peasley landed a twenty-one pound musky that scrapped like a thoroughbred, but just the rushing, snappy fight you would expect from a cold spring lake right in the center of the divide between the Mississippi and St. Lawrence waters. Mr. and Mrs. L. H. Davidson, of Chicago, landed fine strings of bass and pike the afternoon we met a few nice small-mouth bass.

It is from the waters of Long Lake that O. K. Richards, of Chicago, played the winning fight with a seven-pound four-ounce and a seven-pound eightounce small-mouth bass a couple of seasons ago, which, by the way, are mighty big bronze-backers. These two small-mouth bass are the largest caught in the Midwest for a number of years and $\mathrm{O}$. $\mathrm{K}$. comes up here every year hoping to beat his own high record for these famous small-mouth waters.

Another Chicagoan who summers up at this height of land is Bishop Anderson of the Methodist Episcopal Church. And say, fellows, the bishop is a real, sure enough fisherman. The way he can toss the feathery fancies to the trout family is well worth watching. His favorite trouting-stream is the Alvoy 
Creek, a bit east of Long Lake, and to get there he hits the seven-mile trail like an old-time woodsman. $\mathrm{He}$ also fishes in the Brule River and the Deerskin, which has its source in Long Lake.

The brook-trout fishing in the Alvoy and Brule is excellent, and the Deerskin has stood by its record for rainbow trout this season, as usual. The mouth of the Deerskin down at Scattering Rice Lake has been stocked for a number of years with plenty of rainbow fingerling, and these husky youngsters have worked up to the cooler waters of the upper stream, where they are tickled to death to get a chance at the flies.

Long Lake Lodge has one thing that few fishing resorts can boast of, and that is a chapel. Bishop Anderson, who has his own log-cabin on Long Lake, has a wonderful little chapel built close by, where the overzealous fishermen can hear a few words of wisdom from the bishop before telling their fishstories to their friends back home. I have an idea that the bishop knows how awfully large the fish grow up in Long Lake, and that if the average fisherman ambled home and told the other fellows how large the one was that got away, adding, of course, the natural increase through repetition of the story, the back-home people would get the impression that nothing but prevaricators fished those waters.

Anyway, a fellow is lucky to have a chance to fish 
these waters, and if, at the same time, he has the opportunity to hear Bishop Anderson tell a fish-story or preach a sermon, he is doubly lucky.

Donaldson, $W$ is. - Of all the north woods country of Wisconsin there is none finer than that along the great divide, the ridges of which push the waters to the north and on into the St. Lawrence, and on the other side down into the Gulf of Mexico via the Mississippi and its tributaries. And these streams that flow on and on toward the Atlantic are the favorite waters of the trout family, while those which flow to the south lands are the breeding-homes of the fierce old musky and his family. The ridges are covered with virgin hardwood timber all along from the Lac Vieux Desert waters over to the Cisco waters, and as we ambled along the wheezing cough of the lumber logging trains made strange music in the depths of these sturdy forests.

The cutting-out gangs were busy as a bunch of beavers getting out the hardwood timber, and these husky fellows can snake a log along with about as much speed as I could man-handle a toothpick. For real downright, unalloyed pleasure that is different from anything you have ever experienced before, spend a day with the loggers and hop up into the cab with the throttle-pusher on one of their prehistoric engines and rattle and cough along through the closewalled alleys of maple and oak. There's a sniff to the air that will give you an appetite that you have 
not experienced since the time when you were a kid, and, believe me, a stack of cakes six inches high is merely the opener.

A few days ago I had traveled a bit with George Jackson, the live sheriff of Vilas County, and, besides being a rattling good pal on trail or stream, George stands ace high with the inhabitants of that little county. A drag like that is worth having in the party, and I was tickled when he volunteered, after a little coaxing, to do the Lac Vieux Desert waters with us. On the way out we were held up by a fairly wet settler with a pronounced German accent who had a barrel of bottled hops in the tail end of his buckboard. As soon as this son of the soil spied the sheriff he wanted to make good as to his Americanism, and during his protestation, which included his record on Liberty Bonds, Red Cross, War-saving Stamps, and his personal opinion of the Kaiser, which is censored, he forced us to dispose of a bit of bottled bait with which to toast confusion to the entire Hohenzollern family from Frederick the Great down. As the day was a bit warm and the road a trifle dusty, we toasted with gusto and frequency; in fact, I never knew before that there were so many Hohenzollerns in Germany.

Lac Vieux Desert is one of the largest inland lakes of the North and it nestles in among the hills, a pretty blue gem in a setting of greens of the timbered shore. This is primarily a lake of muskellunge, 
many of the big ones answering to the last call from its waters, although the bass and pike are also taken in good size and fine strings. The lake has forty miles of shore line, pleasingly wooded and with wellhidden bays and numerous islands. An ideal lake for the big game muskies, with enough elbow-room to give them many miles of water range and feed, something that affords them a chance to grow up into the old "he-wop" class, the kind of fish all the real "muskyteers" are looking for at least once in their lifetime.

Here is the home of the Maple Grove Resort Musky Club, the headquarters of which are at the Maple Grove resort, over which Harry Frank presides. And whether Harry Frank is the host at a dinner at the Maple Grove or over the campfire, in the trout stream, or on the lake for musky, he is there forty ways from the jack. He knows fishing from the kiddie days up and is a sportsman clear through the deck, standing for game laws and regulation to help make fishing better each year. The more men of his caliber who get behind the game in the north country will mean much for the great outdoors and the feathers, furs, and fins of its wonderlands.

There is one thing that stands out strong in the musky game at Lac Vieux Desert, and that is the large number of big fish that have been caught there by rank amateurs at fishing for his lordship. Last 
season seven muskies of over forty pounds were landed by fishermen who had never fished for musky before, and two of over forty pounds were landed by ladies on their first foray after these husky roughnecks. It sure is queer dope, this horseshoe stuff of the musky game. A' regular, sure-enough musky fiend may follow it for years and not get one over the twenty-five mark, and along comes a tenderfoot who knocks over the cards to the tune of a fortypounder. And after a rattling fight of an hour or so he lands the old-timer, from which time on he never fails to tell the story, which, by the way, is a story worth being able to tell at that.

The Maple Grove is located right on the divide, and while the waters of Lac Vieux Desert head for the Mississippi, the streams to the north and east rustle and gurgle along to the St. Lawrence. Brooktrout fishing in these north-bound streams is ideal, and a fellow should bring along his fly-rod for a cast at these swift scrappers. From Paint Creek, a short trail from the big lake, we brought back thirty brooktrout that tipped the scales just a tremble under fourteen pounds, which I might say is some fine brooktrout fishing, an average near to the half-pound mark. And they were a sassy lot of tail-kickers, being in no way particular about the kind or style of fly that was tossed to them. They simply took it with a walloping punch.

Dan Padnote, one of the Maple Grove guides, 
tells a good one that bears repeating. Last season he guided a beginner who insisted on using a spoon with a spread of two and a half inches and a length of six inches. A spoon of this size is generally wished on a beginner by an overzealous tackle salesman and never toted by a regular. Trolling over to the musky waters one day the big spoon hooked a thirty-two pounder and the next day a twenty-eight pounder fell for it. On leaving for home the beginner presented the big bunch of nickeled brass to Dan as a parting gift, and Dan says he dragged that spoon all around the lake for the rest of the season, raking up half the weeds in the lake and never got a strike. But that's the musky game. Sometime you get 'em and sometime otherwise, but when you do connect up with a full-grown musky from the cold water of Lac Vieux Desert, it's a fight worth while, a fight to the finish. 


\section{BAIT-CASTING RODS}

The short bait-casting rod, that great little joybringer that put the fishing game on the map with a cap $\mathrm{M},-$ in fact, popularized the sport of coaxing the gay tail-kickers out of their watery recesses,made it a recreation that most anybody could kick into without growing gray-whiskered learning the art. Can the main bunch of us fellows of the common herd ever thank it enough?

After the long cane pole of the ruddy-cheeked, barefeet stage of our angling days it was quite a jump to the long, slender, fly-casting rod and many fellows slipped up on the effort and stuck to the still-fishing sport. When some one, the Lord only knows who (and, believe me, there are enough claimants, really so many that I have not the space to name 'em all), out in the mid-West section, invented the short rod for the snappy overhead cast. You see the grand old bass family sort of made their headquarters in the many lakes of Michigan, Wisconsin, and Minnesota, and the local boys were not getting the big ones that loafed in the weed-beds and pockets. The approach to these hangouts had to be made without advising the bass in advance and 
a fair to long cast was necessary to get the bait there from a distance. For this reason some old-time scout of the water-trails slipped his think-tank into high, pushed on the gas, and evolved the short baitcaster. Then probably, like a regular fisherman, he sneaked out and came home with a string of big ones just to show the rest of the gang what a wonderful fisherman he really was.

But you cannot keep a good thing buried, so the bait-casting rod came into rapid popularity and along with it came the wooden baits and bucktail lures. The act of casting the bait with the short rod could be mastered in a few hours, although, of course, one could not become particularly accurate in such a short time; nevertheless, you could toss out the bait and reel it in, which carried enough of a thrill to interest you until practice brought perfection in placing and handling the lure where it would do the most good among the fish and his friends.

Thanks can be offered up to the short bait-casting rod by many, many thousands of fishermen for interesting them in a sport that has made their days happier and their life longer. After having lamped the glow of satisfaction wreathing the face of a beginner at the game, after a few hours on the water, I lift up a little prayer of thanks to the gay old waterdog who thought out the short rod, and I also pass a bit of a growl on the hectic highbrow who is eternally damning this method of fishing as being more 
or less of a bore and not as high-class as what he calls the "high art of angling," namely, tossing the feathery fancies to the spotted tail-kickers.

Fellows, the bait-tosser is just as much a fisherman, or angler if you please, Mr. Highbrow, as any other fishing-fan, and to handle the bait-casting rod right is not child's play by a long shot. After becoming a bit skilled in the art and using the light whippy split-bamboo of say three or four ounces, landing the bronze backer or his big-mouthed cousin is some sport. Of course, a fellow starting into the game of bait-casting has no right to subject one of these real light wooden rods to the sudden jerks of "buck fever" that are sure to mantle his fevered brow when the first few big ones swirl up in that pleasing curve and swipe the bait. A bit stiffer rod is better for the beginner, and it can be of either split bamboo, the solid woods, or steel, as his wishes indicate and his pocket-book allow.

I feel that it is the loving duty of every follower of the lake and stream trails to encourage and assist any poor deluded mortal, who does not follow the sport of fishing, so that he becomes a devotee of this great national nature pastime that gives us all health, happiness, and pleasure, not to mention the opportunities to stretch our imagination and veracity on the length of the ones that get away. And there is no easier way for the other fellow to get into the game than by wrapping his paws around the butt 
grip of a short bait-casting rod. As he develops in skill he naturally swings along into fly casting and enjoys that thrill producer, but never does he wholly give up his first love, the short rod. He does, however, go in for finer tackle, as his skill makes the use of such tools a joy, and the keen sport of playing the fish on the light rod is real sport, be it the short rod or the ten-footer of the running stream or bubbling brook.

Taken every way from the jack split bamboo is the most consistent worker in the wooden rods, it is full of life and action, light and graceful, and it sure can toss out the plug, live bait, spoon, or most any lure that can be rigged and does it with little effort on the part of the caster. It has strength and pliancy, and is the most resilient of the woods.

In bait-casting many fellows have a bit of trouble casting the lighter lures, the spoon rigged with pork rind or minnow or the bass fly and light spinner. This trouble is generally in the tip, as the split bamboo that is stiff enough to handle the heavier plugs has too much backbone and is not pliant or, in other words, is not whippy enough to speed out the light lures. For this reason a rod equipped with two tips, one light and pliant and the other a bit stiffer for the heavier plugs and lures, makes an ideal baitcaster. At the same time it is good policy to use a lighter line when casting the light lures, say a No. 6 soft braided, and for the plugs you can go one 
point heavier and use a No. 5. Although after casting a bit you will find the No. 6 line the one you will probably tie to as the one best bet for most any kind of casting.

Naturally, the one-piece rod is the real dinger of the split-bamboo family, either with the butt attached or with it detachable to make it easier to handle in traveling. Of all the fishing kit there is nothing more unhandy to tote around than a onepiece rod. It is eternally slipping in under the feet, poking the innocent bystander's eyebrow off, or flirting with the porter's legs as he tries to amble up the aisle of the sleeper as you hit the steel for the faraway fishing waters. At the permanent camp where there is no chance of the one-piecer getting into trouble it is a joy unto itself. Once you feel the swing and whip of a one-piece rod, it is sure your pet, and you love it like a long-lost brother, swearing by it for the rest of your natural life and hopin' that you fish the Milky Way with one when you go to the happy hunting-grounds.

The next best bet, and the rod most used, is the two-piece one designed with the long tip and short butt. This rod comes the nearest to retaining the resiliency and lively action of the one-piece rod, and the type of long-tip, short-butt rod is made commercially in the medium-priced rods more than the onepiece affair which generally runs higher up the price scale. The reason the rod of this style retains the 
whip of the single piece of bamboo is because the ferrule is set well below the middle of the rod and there is no stiffening ferrule up where the natural bend and curve comes when the game-fish pulls the arch in the rod that eventually kills him. It is natural that the most strain on a rod would come above the center, up where the tip lightens off, and to weaken this end of the rod with a ferrule renders it more subject to breakage, especially when handled by the beginner, who is likely to play the rod at an angle that will make the pulling fish overstrain it.

The real skill in handling a bait-casting rod is to make the pull or spring of the rod kill the fish and not merely reel him in so fast that you drown him. With the ferrule well below the center you get a natural unbroken curve to the tip, the strain is about equally distributed and this brings into play the lively action of the rod. The beginner in playing a fish will often try to hold the fish too short, with the result that the tip snaps. It is well to play the rod so that the fighting bass has a bit of a pull to take the line, and in so doing the rod swings to a natural curve that will soon tire the kicking lunker. As the full enjoyment of landing a fish comes from the playing with the rod springing in a well-balanced curve, making it a case of give and take of the line, the two-piece rod will make the pleasure of landing your fish keener and more enjoyable.

I am not quite sure, but I believe that the late 
Jim Heddon was the originator of the long-tip and short-butt style of rod in split bamboo. At least, way back when they first came into use I had one of the early ones. In cost me the great sum of $\$ 2.50$, and many were the happy days that old rod gave me. Fact is, it is still almost as good as the day it came to me and it hangs in a place of honor in my cabinet at Timberedge. This fall I had it out for a little work, and it is surprising what fine action that old rod still has tied up in its system.

It is odd how a fellow becomes attached to a rod, either because of the action and feel or through associations. While chinning with Claude Refner, the man who makes a rattling good floating bass bug, and who has turned out a lot of fine handmade rods in his short lifetime, he told me of a little rod story that happened down on the Pleasant Lake chain in the northeastern end of Indiana, which, by the way, is a good piece of bass waters. Ref had dropped in on an old-time fisherman, down that way, Bradley by name, and standing in the corner was one of those old dollar-and-a-half one-piecers put out by Heddon. It had been worn some and needed a line of repair, and Claude carted it home to fix it up for the old man. He put in about ten bucks' worth of time on the rod, wrapped it well in vari-colored silks, and sent it back to Bradley, with his compliments, for the many days of pleasure he had spent on the waters with him. 
Dropping down for a bit of bassing the following season, the rod had the place of honor above the clock and the old man had hauled out another older one and was using that as his favorite. Would he take that dolled-up affair out and wet it? No, siree, boy, he just kept it at the cabin to whip about a bit in that dry air easy-chair fishing we all do once in awhile when we are far from the favorite lake or stream. That's the game, though, once you get a rod that has the feel, the hang of your arm, you just simply raise it a pet, and as far as borrowing it goes, good night! let any one dare throw a cast with it but your own self.

Getting back to the style of rods, the next we have is the three-piece affair, and if one cannot secure a two-piece rod then the three-piece would be the next choice. The main thing in its favor is that it packs easy and is handier to carry than the longer ones. You can slip this rod into most any suit-case and forget it until you hit the water, but I am willing to go a little out of my way in handling a piece of tackle that I think will make the pleasure keener when on the water. Naturally, wherever you put a ferrule on a rod you cut out some of the action of the wood, but even so the three-piece rod is more active and stronger under a strain than the two-piece rod with the ferrule right in the center.

To get the right balance and feel to a rod is the main thing to look for in making a selection. A rod 
that seems to have too much weight beyond the first guide and feels heavy or unwieldy is over-weighted for you and does not have even balance. Although few bait-casting rods are out of balance, if you do get one that is, it will be rather tiring on the wrist after you have whipped it a few hours. Taking up a few bait-casting rods and making the casting movement with them one after another will show you the difference in balance, while the one that seems to swing in an easy sweep with the wrist and in unison with the movement of the forearm is the rod that has the right feel and which should be your selection for the best results at the casting game.

In the matter of length to a bait-casting rod, this is usually a personal choice. Some of the fellows cotton to the real short four or four-and-a-half footer; I do not. You cannot get the right action in a real short.rod, and playing the fish is not half the sport that you get out of the longer rods. In length, I find that the five-foot rod gives me the best results for casting the plugs and heavier lures, while the five-and-a-half footer for the lures running around a half ounce and lighter just suits the swing of my arm, which is a short member at that. Even the six-footer for the spoons and spinners with pork rind or bass fly makes a rather fine tool for this style of bait. And you get far more action in playing the fish with the longer rod, it is easier to learn 
to handle the fish with this style, and for all round good service a rod of five foot or over will fill the bill with more satisfaction than the real short ones. 


\section{THE STEEL BAIT-CASTING ROD AND SOMETHING DIFFERENT}

As the split-bamboo of the woods is conceded the finest tool in the bait-casting rod line, being light, resilient, and active, so is the steel rod placed in the position of being the best rod for the beginner. The light split-bamboo rod is too fine a piece of kit to be given the rough handling a beginner generally is sure to give it, especially when he gets a strike and goes to pieces trying to drag the battling game-fin through the water, in order to drown him before the fish gets to the landing-net. And at that said beginner has a perfect right to shoot into high when he feels the swirling strike of the bass, pike, or musky on his early trips to the waterlands. And should he lamp the big one as he breaks water, usually the effort to draw him home to "uncle" is speeded up by the sight of the game one's plunge into the air.

There is hardly a split-bamboo that will not break with a dead weight of five or six pounds, and on the strike of the live-wire of the weed-beds the rod is jerked back to an angle that puts too much pull on the light tip and a smashed rod is the result, before one realizes or becomes skilled enough in 


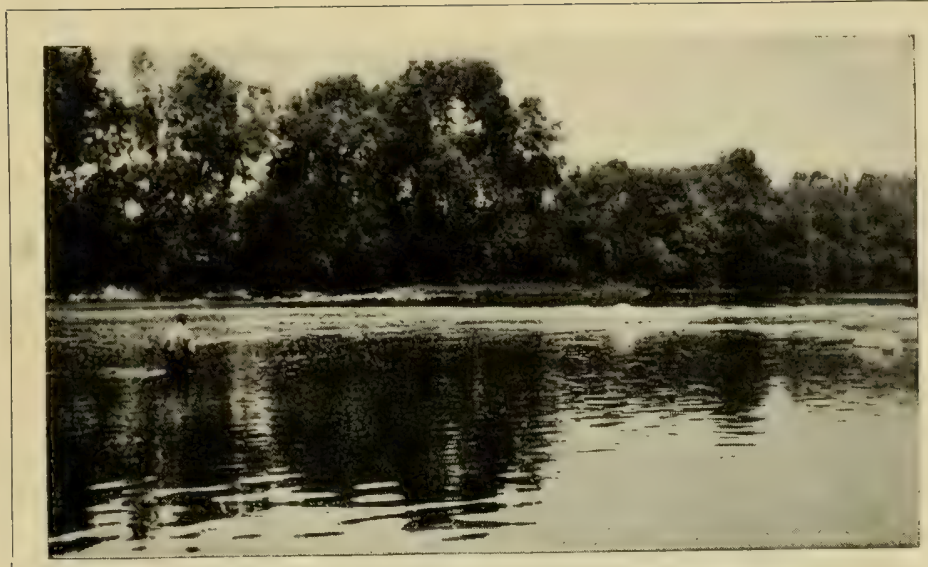

Fishing this bass pool right below the riffles is just naturally productive of results. The bass like to feed on the minnows that battle the swifter waters of the riffs and then when tired out swim into the pool for a rest. Easy feeding for the bass and wall-eye pike and they know it. A live minnow is a rattling good bait here as is the helgramite. Just sort of toss the minnow out lightly and let it move a bit with the current.

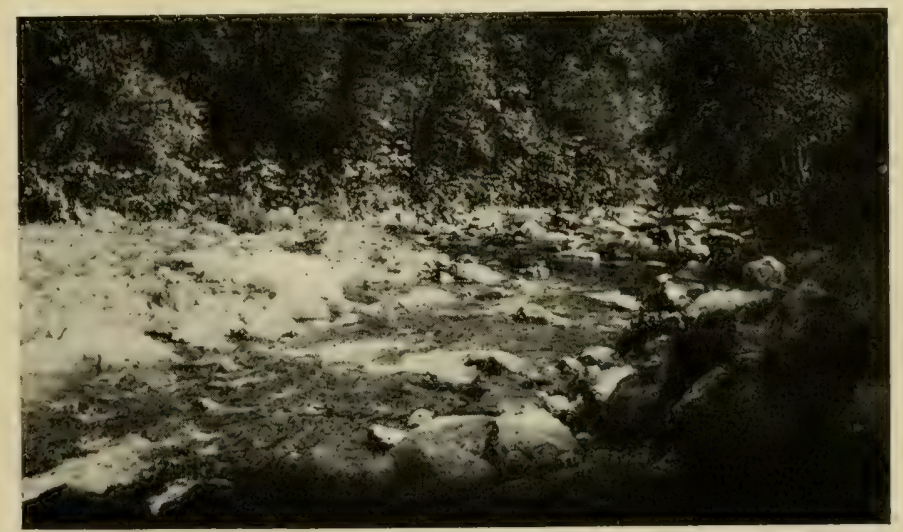

A tumbling little trout stream along which you can cast the fly with the overhead cast and not tangle up in the brush. You can fish this water all the way; it is good trout water. 

handling the rod to know that only a slight swing is necessary to set the hook and then the game is to let the fish take a bit of line, meanwhile holding the rod so that there is a slight curve in it which gives just enough pressure to make the game-fin pull a little for the line he takes and thus eventually tiring the fish instead of dislocating its jaw via the yanking process.

Then, again, handling the bass in among the weeds, where they love to loaf, using the often necessary derricking movement to work him away from these pests to the fisherman and safety firsts of the fish, it takes quite a bit of skill on the part of the angler to handle the rod and come out of the fight with the split-bamboo in good shape. While with the steel bait-casting rod you can afford to derrick or pump the fish out of the weeds without having an attack of heart-failure at the thought of the rod breaking, not to mention the escape of your prize on the business end of the line. From this, however, you must not get the idea that the steel rod is only good for rough work or that it should be subjected to any rougher handling than you must give it, as a good light steel rod, handled skilfully by an angler, produces a rattling fine piece of sport, and although slightly heavier than the split-bamboo rod of the same length, the difference in weight is not such that it is noticeable in a day's casting.

Many fellows have started at the bait-casting 
game with a steel rod, and after many years of fishing continue to use that style of rod, and one reason, I believe, for this sticking to the steel is that this style of rod seldom, if ever, gets out of order, and if it should happen through accident that a break occurs, it is a simple matter to make a repair and go right on casting. There is one little old veteran steel rod that I know of up in the north woods that started its bait-casting days as a five-and-a-half footer some ten years ago. A number of breaks and accidents along the trails and streams have reduced this pet to a trifle below four feet overall, the guides have been resoldered a number of times, the enamel has passed away, and the rod looks like the tail end of a hard winter; yet this old pal of a rod made a 3 I $1 / 2$-pound musky come up to the gaff without a quiver in its short length, and it's still good for many a cast.

You can generally depend upon a steel rod being ready for use at any time and there is no need of revarnishing and winding it each season. About all that is necessary is to wipe it dry after each fishing trip, rub it over with an oiled rag, and lay it away until the next foray. That this is important, the drying of the steel rod, a thing that some fellows do not bother about simply because it is steel and they have the opinion that it should stand for any kind of treatment, was shown to me quite conclusively a few days ago. I had loaned a friend a rod 
last summer and during the week he developed a guilty conscience and returned it. I put the rod together, gave it a couple of whips to feel the action before standing it in the rack, when something snapped and it whipped with quite a wobble. On taking it apart I found that it had developed a rust spot above the second joint where the enamel had chipped a trifle, and this small spot had increased and eaten through the steel close to the ferrule, with the result that the rod broke when being disjointed. A little oil and a rag would have prevented this, as once a rust spot starts it will eat in deeper after each wetting. But such is the result of one loaning his tackle to a friend, stuff that he raises a pet, only to have it get a jolt through carelessness of the one who borrows it.

That the steel rod is popular with the ordinary fisherman as well as the beginner can be seen by a census of the rods being used on any of the north woods lakes. Here you will find more steel rods doing their bit than all other rods combined, and this is particularly so of the waters the big old musky or pike happen to grace with their presence. I have one Bristol steel rod that has been in my kit for slightly over fourteen years, and I have always looked on this rod as a piece of rod insurance. I invariably carry this rod into the hinterlands regardless of what other rods I may take along, beçause I know that should the lighter ones become broken 
through carelessness or accident, that this old reliable will be there as an understudy. And when you smash a rod far enough away from the repair shop and a few days by canoe or trail into the woods, believe me, friend, an old pet in the shape of a steel rod is sure a welcome sight.

Usually the steel rod is of three-piece construction and of this style rod it is the best, as the ferrules do not interfere with the swing or action of the cast. The three-piece rod with separate grip is an easy rod to pack and an all round good worker. A rod of this style can be had in the heavier designs and also in the light whippy affair that has almost the feel of a wooden rod, yet plenty of backbone that will stand the strain of pumping them in out of the weeds if it looks like a sudden getaway of the gamefish. The four-piece, very short sections with separate butt, designed as a pocket rod, and a mighty handy tool to carry is built slightly lighter than the three-piece rods and is a snappy casting rod.

The adjustable telescopic steel bait-casting rod is a very handy specialty in the rod game, the rod telescoping from the smaller tip down, and as the butt grip is detachable it makes a very good rod to pack along as the emergency rod. This rod can be adjusted from five and a half feet down, and the sections are locked at the desired length by patented guides. You can use it as a five-and-a-half footer for the lighter spinners and pork rind when all the 
whip of the rod is found useful in helping cast out these light lures, or you can lower it down to five feet, reduce the whippiness a trifle, and have a good caster for the heavier plugs and lures, while running it down to three or four feet makes an ideal trolling rod. This rod comes nearer to being the real emergency and all-round rod of the bait caster and is a fine light caster that will stand the gaff of most any kind of handling.

When it comes to class and style in the steel-rod family, and one that kicks right up front as a nifty affair, you gotta get acquainted with the all-silk wound fellow that looks so much like a split-bamboo that you would take it for that rod's twin sister. After putting in a few days casting with one of these "good-lookers" I came to the conclusion that the all-silk wound steel rod becomes more resilient and has more whip after it is wound with the silk; it seems to take on more of the action of the rods of wood. A couple of years ago I sent an old used steel rod, that had brought many game ones to gaff, to W. H. Tallett, of Watertown, N. Y., who winds any old steel rod with silk and makes it look like a million dollars. When that rod came back and I felt the whip and action of it on a few casting bouts, I found that this old rod about ready to go home to its last resting-place had come back with a snap and feel to it that was almost impossible to believe. Since then I have had a number of old rods brought 
up-to-date, and I find even the lighter ones retain wonderful action and that they are practically indestructible. The silk is waterproof and varnished the same as the wooden rods, and besides the classy appearance the all-wound rod makes, I know of no rod that is stronger or more sturdy and one that retains action and life, than a rod of this kind.

The requirements of a casting rod are strength, lightness, and casting power. It must have backbone enough to make long casts with precision, yet have whip enough to place the short cast with ease and accuracy. This is a combination you will usually find in a good steel rod, and it makes fishing a pleasure to find the rod that will do the most things the best way, particularly if you happen to be a beginner at the sport.

Although the steel rod is naturally a stronger tool than the rods of wood, some fellows make the mistake of handling it roughly, and for this reason it was only until recent years that a rod-maker would take a chance on his reputation and turn out a real light steel rod. Now you can get a steel rod that is light and fine and one that any angler would be glad to use.

Any rod should be handled with as much skill as the caster has acquired, and playing the fish right with a light steel rod calls for just as fine handling as one would give to the wooden rods. This is not only good medicine for the rod, but it develops the 
skill of the angler and tends to make him depend upon his handling of the rod and not the strength of the rod itself, not to mention the added sport he gets out of the game by giving the fish half a chance for his white alley.

During the past few years I have had a wonderful bit of fun out of a somewhat different kind of a rod, and the game has been so full of sport and pleasure that I feel like a rather selfish sort of a yap to keep it buried.

This something different in the rod line is made of Spanish rattan and besides the two rods that I have, I do not know of more than three others of the same material in the country. I am not the discoverer of this wood for bait-casting rods, by the way, in fact, I dropped on to it entirely by accident while talking over the fishing game a few years ago with Charley Sweder, of Chicago, one of the keenest oldtime fishermen of the mid-West waters and who knows and has fished during the past fifty years more of the lakes and streams of the north woods than probably any other angler. Charley was a personal friend and fishing pal of the late Frank Forester, famous throughout the land as the father of the angling game.

A couple years before the big war broke loose over on the other side a salesman, for an English whip concern, making the West, dropped a bit off his feed while hitting the high spots in Chicago, and 
needing the help of a physician, and a good one, he wandered into the office of Dr. C. H. Bryan out at $43 \mathrm{~d}$ and Indiana Avenue. The Doc rolled up his sleeves, gave him the once over and everything but his diploma, which put the visitor right up on his toes. The salesman was so tickled at being able to once again demolish his regular portion of roast beef, that he called on Dr. Bryan to pay his respects before hitting the trail for home, but this time he caught the medico unawares while he was winding a new rod for a foray on the unsuspecting bass family. It happened the Doctor was a regular fishingfan and would rather go fishing any day than look down your throat, feel your pulse, get a wireless message from your heart via the stethoscope, or just feed you pills, and seeing the Doc was some interested in the game the salesman suggested that he send him a piece of Spanish rattan when he got back in dear old England and to try that out as a rod wood.

About six months later Dr. Bryan received a stick of this wood through the custom-house and rounded up Charley Sweder to make it into a bait-casting rod, as his own time was fully taken up with patients who really needed a fishing trip more than a shot of medicine, as no doubt the good doctor will agree. The rod turned out to be a rattling good one, it weighed only six and a half ounces, although it appeared a good deal heavier and the whip it had was a sight 
to see. In making the first few casts, before getting on to the hang of handling it, the rod shot the bait out in front a little and then the backward swish was so quick on the return that the bait came right along and landed behind the boat. And on the first strike, the rod was so limber that it bent almost double, with the result that the strike in setting the hook answered so feebly that the points merely tickled the mouth of the bass and away he tailed.

After getting the lay of the rod the Doc not only found it a rather good one, but also that it was a gold mine in the trick rod line. It became quite a thing to give it to a fishing pal who was not acquainted with its peculiarities and lay back in the boat and enjoy the show as the friend made a few passes with it and then began to swear.

As soon as I got on the trail of this rod, I started on the still hunt for a piece of Spanish rattan, but failed to find the raw wood until, one day while browsing around with Charley Sweder, we located a number of English coach whips, the stick of which is made of Spanish rattan, and very shortly afterward I had one of these limber rods in my kit and hit the steel for Timberedge Lodge, to try it out on the bass, musky, and pike of the waters thereabouts.

It took just a bit of practice before I could toss a well-delivered bait with this rod, it being so willowy and full of action. But, say, lad, when the fighting musky happened to connect up with the 
bait on the off-end of this rod, it sure was a rather exciting fight and then some. After the first strike, and when I had almost yanked my arm off to set the hook, the game old bird made a run and then, fellows, was the first time that I actually had a fish "bend the rod double" in every sense of the word. Holding the rod with the butt grip at an angle of forty-five degrees slant backwards, that old game-one sure made the line sing and the rod curve until the tip almost touched the butt. It was a fight worth while and one that I remember more vividly than any other, that first big musky landed with this new rod.

The rod of Spanish rattan is an easy one to make for the fellow who likes to make some of his own rods. First, of course, you must locate a piece of rattan, then all you do is smooth it down a bit and wind it according to your own likes, varnishing it the same as a split-bamboo or any other wood. To stiffen it a trifle, if you happen to land a real whippy piece of rattan, you simply wind the rod entirely with the spiral style of winding. This will give it more backbone and make a dandy caster of it. My second rod of this wood is wound with the spiral windings and is far better as a regular casting rod than the first one on which the wrappings are spaced about $2 \mathrm{I} / 2$ inches, beginning at the butt and graduating a little closer on each wrap toward the top. The rod had the best action when made as a one-piecer, or with a 
long tip one-piecer with separate butt, although no doubt a very good rod could be made with a longtip and short-butt design like the popular split-bamboo, made famous by Jim Heddon.

Coming down to cases again on the steel rod, after running amuck on the Spanish rattan, for a small investment you can get a right good steel bait-caster, and one that will give you many years of service; that is, if you buy one that carries a good square name behind it. Dollar for dollar in the lowerpriced rods, the beginner can get more value in a steel rod than in the woods, as a wooden rod at the same price one pays for a good steel rod will naturally have to be one of the lower-priced rods in that style.

For night-fishing the steel rod is a winner. Then you need a rod that you can work without fear, and there is not much chance to use as much skill as in daylight work, and skill in handling means the very life of a split-bamboo. For the emergency rod the steel gives you a comforting knowledge that no matter what happens far away from the home port, you have an understudy on hand to take the place of the star when the time comes. All the way around the steel rod is one that will be found handy and useful to any angler, whether he happens to be a beginner or one of the old-timers. 


\section{THE OUTBOARD MOTOR IN FISHING}

GETS YOU THERE AND BACK AGAIN WITHOUT BREAKING YOUR BACK

Way back in the dim and dusty past, when Rags was a purp and my main run of wisdom teeth were just about in the hatch, I prided myself on doing the outdoors via the hardship route. "Roughing it" was my main squeel and I sure treated my system to a regular diet of making a trip with a blanket, a tarp, a pan or two, and such light equipment, and you can take it or leave it, when I look back over some of those trips up among the Blue Ridge Mountains, I wonder how I did it without developing everything from house-maid's knee to a life-long love for Peruna. Long were the trails by day and hard were the beds at night, not to mention the long tiresome pulls up some of the streams and lakes, when you thought your back was due for a break on the next stroke of the oars. In those old roughing-it days, I just had to show an old granddad, who was ninety-two and past, and who could knock a squirrel out of a tall hickory with his long Kentucky rifle as clean cut as any of the younger fry, that none of the long-gone Indians had anything on me in the way of 
standing torture. This keen old forebear was eternally telling me of the wonderful endurance of the Indians and how they made the trails with nothing but a powder-and-bullet pouch and a blanket.

Since those early days trying to lay one over on the Indian, I have learned many things: that you can sleep on a pile of rocks and feel comfy if you happen to have the right bed; that the waterproof tent of light sail-cloth keeps the rain in the right place, on the outside, and oh, boy! that great little boon to the outdoorsman, the outboard motor will make your water work as easy as playing the little game o' seven-up at the evening camp-fire.

Just as the auto has been such a great little machine to bring the lakes and streams, fields and trails, closer to the fellow who lives in the cities and towns, so has the outboard motor been the little pal that has brought the far reaches of the waters to us. And the beauty of the outboard motor is that it is not a bit complicated, nor is it a difficult thing to learn to run. I never have had an itching palm for a screw-driver and a monkey-wrench to take everything apart to see what makes the "thing-ga-majig" mesh with the "doo-dad," and because the men who planned the outboard motor designed a machine that is about as fool-proof as you can get a machine, I have never had the least trouble with a fleet of five different kickers located in different parts of the country where they will do me the most good. I just 
have to start 'em and they go, go anywhere I want 'em to, and I sit back as lazy as can be and hit the old Henry Clay, thanking the keen fellows, who thought 'em out, for making any fishing and hunting trips so pleasant.

I have an outboard at my head-camp, Timberedge Lodge up in northern Wisconsin, and that little old joy-throbber has been fooled with by perhaps two hundred different people, treated somewhat rough at times and by some of the gang whose knowledge of machinery is limited to the works of a watch, yet, when you give it the juice it throbs right along and takes you up the chain o' lakes without a murmur. Although this kicker has not been raised a pet by any means, it is always on the job and willing to speed along merrily whenever needed. And it always brings the crowd back.

Not only do I recall the many days of pleasure on lake and stream that can be credited to my outboard motor, because it got me there without my breaking my back at the oars or paddle, to reach far fishing waters and reach them as the sun tipped the eastern horizon, just when the game-ones were eager for the feed, but some five years ago this outboard o' mine saved the life of a pal with whom I was shooting partridge up Wisconsin way. And for this help in an emergency I lay another good word for this little machine.

Three of us were covering a tote-road along a 
piece of cut-over: Mac, as keen an outer as ever followed a trail; Dave, a youngster new at the wood's game, but keen to learn the wonders of the outdoors, although a little nervous on the trigger finger,- in fact, a bit short on the "look-see" stunt before you shoot,- and myself. We were covering a fine stretch of bird country and had bagged a few nice ones, with the usual misses chalked up against us. You know, fellows, the misses that happen to a chap hunting these clever speedy wild ones, but seldom happening to the front-porch specie of hunter.

Mac had the kid in tow and had flushed a nice pair to the left of the road and they had winged it off toward a ridge. Giving the kid the high sign to follow the flight of the birds, Mac circled over to flush them so that the youngster could even up his bag, as a northeaster had started to blow and we were to head back for the boat as soon as the kid could get this chance for a last shot. Mac had not gone more than ninety feet when, with a whirr, two birds raised right in front of him and the kid threw up his gun and gave 'em both barrels, right straight for good old Mac.

Somehow, we got Mac down to the boat, the kid being practically useless as an assistant, his nerves busting when he saw what his shooting without thought had done. And say, lads, that little old outboard motor carried us down along ten miles of windtossed, white-capped lake and stream waters like a 
thoroughbred. Crossing some of the wide open stretches where the nor'easter played merry hell with the water, it looked like a short shift for all of us a number of times, but the steady kicking of " li'le Joe," our pet name for the motor, carried us head-on through the big ones. And, believe me, with Mac's head and shoulders on my lap trying to ease up the ride for the good old scout and only one hand to steer, as well as attend to the motor, I was sure glad that it worked "on its own " and needed hardly any attention.

Later, in the hospital at Ashland, the medico said, speed in getting Mac to where he could have proper attention had saved his life, and this after. the old cut-up had taken 286 shot out of his side and arm, not to mention three from the case of his watch. We had just made the railroad twenty minutes before the last train north was due, flagged it, and rode the baggage to Ashland, Mac in the meantime having slipped into semi-unconsciousness, remarking that the water was sure getting rougher, which only goes to show that we were on "some" railroad.

Besides the regular uses of the outboard motor, which are legion, you never can tell when it will save the day by doing something just a little out of the ordinary. I am the happy possessor of a thirtyfoot cruiser, the "Dixie-Rose," with which I have had keen sport on the inland rivers and lakes. It carries a $I 2 h$. p. Waterman engine that has always 
treated me as a perfect gentleman, no matter how I manipulate it. And it carries the "D.-R." along at a merry pace, towing a short stubby dory for fishing trips in the coves and inlets beyond her draft.

Last summer the kid brother dropped in on me with a ten days' furlough from the Navy, and wishing to show him all I knew about deep sea-water work, I took him up to the Georgian Bay waters on the "Dixie-Rose." It happened that the kid had done a stretch on one of those sharp knife-like submarine chasers, and before we started nothing would do but that he overhaul the engine, fix 'er compression, put in new packing, and do a lot of things to the poor old girl that I never knew a perfectly good engine would stand for. He probably got most of the innards back in the right place, because we ran along for three days without a cough; then, in among the many bays of the Georgian waters, she threw up the sponge and quit - and quit cold at that. After spending half a day doing everything but blowing up the gas-tank the kid admitted he didn't know a darned thing about an engine, but wanted to get a bit of practice to land a higher rating in the Navy.

Once more the outboard does its bit. I carry one stuck back under the aft deck to kick the dory along up the small streams and shallow bays, so I hauled it out, hung it over the side and the kicker brought us into the nearest port, just as proud as a peacock. You can't beat 'em, they do what they are originally 
intended to do and many other big jobs when you are in a pinch for a bit of a lift.

Easy to carry and easy to pack, they put so much joy in the water-game that a fellow is sure foolish not to take one along. Who in the outfit likes to get up at three A. M. with the prospect of a three or four miles' row to the fishing-grounds down at the other end of the lake? By the time you get there you are in a devil of a humor and poor company to the pal, with the chances that you have missed a good hour's fishing just when the fishin' is at its best. And then again, if you want to take a shot at the little lake up the channel a few miles, you don't find it necessary to use up a whole day to go and return; fact is, you can slip up there, fish the best waters, and be back in a couple hours with the help of the outboard. And all the way through there is no keener sport than to kick out before breakfast, land a couple nice ones, and bring back the breakfast before the rest of the gang are out of the hay. And, great guns! no more arguments on who takes the oars while the other fellows cast; just let her limp along slow and easy.

There are a lot of fellows who chirp about the exhilarating exercise of the row to the duck-blind in the early A. M., but most of my duck-hunting is done when the mornings are rather cold and chill, and a good, long stiff row out to a blind makes you start far earlier than necessary and does anything 
but add to the pleasant disposition you usually start out with. I like to smooth the game as much as possible, so I hang on the outboard, give it a turn, and chug along to the shooting-grounds in a short spurt, get a few, or miss a few, and come chugging back for a bit of kitchen gossip with the guy who makes the chow.

As I said before, any one can run one of these little useful fellows, even I can manipulate one without a hitch, and mechanical ability is one of my bad friends. It must be the fact that there is so much solid comfort in lounging back in the boat without a hip-stitch of work to do, in order to cover a ten-mile stretch of water, that makes these motors come natural to a fellow who don't know the ace from the jack in the motor-game. I have had fellows up at my place who never saw an outboard motor, send them down to the boat, and after sitting looking at the machine for a minute or two, they cross their fingers, give it a twist, say a few words of magic, and away they go, looking as all-fired proud as though they had invented the darned thing.

What made a big hit with me in the outboardmotor game was that they got you there and back again, and even some of the old-time models that I have had for six and eight years run just as smooth and are just as reliable as the day I took them out of the shipping-case. They have to be made right to pass through a life like they lead from my semi- 
mechanical handling, and now the later models come along with all kinds of added improvements that make my old pals look like "also rans."

If it came to a show down and I had to split my outfit on account of excess weight and bulk, there are lots of things I would leave out and get along without before I would leave behind my outboard motor. Not because I am particularly lazy and like to be pushed along without exertion, but for the simple reason that the outboard motor can do so many things, save so much valuable time in the outlands where every minute counts, and do so much of the unnecessary hard work that I just must tote it along for its value. 


\section{FOOTWEAR FOR THE OUTDOORS}

GIVING THE FEET A CHANCE, OR THE KICKS THAT MAKE US HAPPY

Sometime back in the musty past, when Napoleon was hitting the trails over Europe, history tells us that this wise bird of his day said that an army travels on its stomach. This may be one of the essentials of the traveling end of an army, but I think that my old friend Sergeant Buck Stehle, late with the colors, "somewhere in France," had a bit more of the right idea when he said, "Our old pal Nap may have been right in his time on what the army travels on, but for me, I'll take a chance on feeding my squad off the country if you'll fit 'em right in the shoe end, and they will travel better and farther than Napoleon's men at that."

And fitting the foot right will keep you on your feet while the other fellow nurses a nice collection of blisters caused by too tight a shoe, one that does not lace snug across the instep, or a loose fit in the heel which allows a wobbling move that can wear a blister quicker than any other mis-fit. The shoe is without doubt the most important part of the kit and particularly for the fellow who has been kick- 
ing around the civilized trails of the city the greater part of the year in light shoes.

During those hibernating months in the city there is one great little treat for the feet that has the rest of the shoe family backed off the boards, and that is the Munson Last Army Shoe. Most fellows think of this shoe as only for use on the hike in the woods, and such was my opinion up to six years ago, when I first became acquainted with this wonder worker for tired feet. I had taken a pair of Army Shoes into the woods on a trip of three weeks and found them so delightfully pleasant that I bought another pair on my return from this trip, and have since been wearing the Munson Last right along. And you can take it from me, "fellers," that when it is necessary for me to slip my peds into a pair of fancy pumps for a night affair to please Friend Wife, I feel like I am parting with a pair of pals in my Army shoes.

These shoes do wonders for the feet; they give the toes a spread that is comfy itself, and when you walk you get a press with the toes that seems to give you a grip on the ground that no other shoe except a moccasin will produce. After wearing these shoes for about three months I noticed that the foot had again taken on the normal shape after years of crowding and squeezing towards a pointed shape produced by the standard styles of the day. There was good breathing space between the toes, in fact, 
the space between the large toe and the next one to it was about an eighth of an inch. The inside of the Munson Last is straight according to the correct shape of the foot, and the shoe fits snugly up under the instep.

The shape of a shoe, of course, is not all of a shoe, by any means, although it is very important and the basis upon which a correct fit can be made. Other points to consider are fit, ventilation, cleanliness, and socks, all of which must be considered in keeping the feet right and free from trouble. And a shoe that is the best ever for one kind of travel may not be at all suitable for some other bit of hiking.

The army shoe is a good all-round shoe for ordinary hiking and for the stay at a fishing-camp where the going will not be of the roughest, but it is a bit light for the rougher trips of the mountain country. Worn with canvas leggins it is an ideal walker for the North Woods, and hobbed with small Hungarian rounded hobs, makes them a better proposition for general use in the woods. The usual thing in hobbing a shoe is to use too many hobs, which has a tendency to stiffen up a sole and also make them pick up stuff under-foot. These cone-shaped Hungarian hobs quickly wear off on the point, but still bite well as they retain a good edge and do not flatten as quickly as the corrugated hobs which slip easier on the rocks than the others. 
The army heads figure that waterproofed shoes were not the right thing for the soldier because the closing of the pores in the leather cuts out the ventilation and causes the feet to perspire and steam, especially if worn in warm weather. However, for the shoe worn in the woods in all kinds of weather, in a bit of snow, through the swamp lands or when $\mathrm{J}$. Pluvius is doing his best for the crops and the worst for the sportsman, then a waterproofed shoe certainly makes the going more comfortable. Of course, a waterproofed shoe will only stay waterproofed as long as the oil or composition remains in the pores of the leather. No shoe is absolutely water-proof for all times, and it will be necessary to put on a preparation every now and then as the shoes demand it. To get the best results the dope must be well rubbed and worked into the leather by the hands. Even at that a waterproofed shoe allows the air to work into the feet, which keeps such a shoe from becoming uncomfortable and unhealthy. As a matter of fact, all that should be required of a shoe is that it shed water under tramping conditions and not be expected to be used for continual wading in water without letting the feet become wet.

However, for general hiking during the warm weather, I prefer the army shoe without any waterproofing at all. Wetting the feet will cause no inconvenience and as long as you keep on walking until they dry, or take them off and change socks and 
shoes when you reach camp, you will not line up with a cold. To dry out the shoes, simply turn them upside down and hang them on a couple of stakes driven into the ground near the fire, keeping them far enough away so that they will not burn, as wet leather sure burns quickly, or rather scorches so that the leather is very weak thereafter. And it is surprising, too, how easily the darned things will scorch. Which reminds me that a very good pal, on a trip last summer, had a rough bit of walking on the return ten miles from an overnight side trip to a lake which we had made from our camp. We had packed light with no extra footwear for such a short stay, and the pal tried to dry out his shoes via the rapid route. He scorched the leather handsomely, at least the aroma thereabouts sure was heavy with burning leather. About a mile down the trail, which was none too clean, as it ran through burnt over and was little used, the pal's shoes started to break through in spots and by the time we made about five miles nearly everything was gone but the soles. With a little ingenuity we doped up a sort of a sandal with the remains and a few thongs from the pack, and the way Pal gingerly made the rest of the trail was a wonderful piece of footwork which would have done credit to the flopping shoes of a Chinaman.

For the canoe trip you gotta pace some to beat the moccasin, and my preference is for the soft buck- 
skin about eight inches high; if the portages are few and not so rough this moccasin will be about right for the entire trip, and you do not have to carry a heavy shoe with you as an extra for the carry over the portages. Although if the carries are long and rough and they come a-plenty, then an extra pair of soled mocs will be handy and save the ankles and feet.

For the fellow who gets about one real trip into the woods after many, many moons in the city, I do not feel like recommending the moccasin without the sole, where much walking is in order, for the reason that the feet are not in condition for the roughing it that will surely come to them if they use the soft moccasin. That is if this moc is to be the main footwear during the trip; on such a trip I would say make it a pair of the regular soft buck-skins for the canoe-work and the soled mocs for the hiking.

For general use around the camp after a husky day on the trail, changing the feet into a nice soft pair of moccasins is the end of a perfect day, and they are a mighty handy thing to slip on when you have to fix up the fire at night. For the fellow who can stand the wearing of the soleless moccasin and like 'em, they are a delight. He goes lightly over the ground and ends up the trail at night with pep and high spirits. For the low moccasin on the slipper order, that fastens with a thong passing around the top, I cannot say much, as I prefer a top of some 
kind on all footwear as a bit of support to the ankles.

For snow-shoeing I have used the soled moccasin or mocpac, and with a light pair of woolen socks next to the feet and two pairs of lumberman's socks I have found them very good, but of recent years I have used the hunting-boot with rubber bottoms and leather uppers. This style of boot makes an ideal piece of foot-gear for the snow-shoe, and I like it so much better than the mocs for this style of traveling that I use these entirely now. Some fellows object to the rubber bottoms as being bad medicine for the feet, but in the winter, with arched inner-soles and three pairs of socks, believe me, you never suffer from cold feet no matter how long the trail. These rubber bottoms have the advantage over the oiled leather boots for winter use in that they do not freeze stiff like the all-leather shoes. This style of boot is a crackerjack for still-hunting and can be used over bare ground or through the snow. With the innersole of leather or fiber, or preferably the arched innersole, and plenty of woolen socks you have warm going in the coldest weather. Shoes with rubber bottoms or soles should be changed at once when you hit the camp, and you will then find that they do not have the tendency to tender up the feet, as has been charged against them.

Another shoe in the rubber-sole line that makes a handy piece of footwear for around the camp is the ordinary sneaker of canvas. This shoe is also 
handy for fishing in the canoe or boat, although not preferable to the moccasin on long trips. A pair of either will be found right for ordinary camp use.

The all-leather boot with the high top has advantages and disadvantages chalked up against it. The main thing is to get a hunting-boot that is not too heavy, as the added weight to be lifted on each foot counts up to a nice total in a day's hunt of from fifteen to twenty miles. For mountain work and hiding, the high-top boot is a very good piece of kit and can be used up to the fifteen-inch height without causing trouble. In rough going in the uplands, the high-top, caulked, will get you over the ground lots of times where other shoes will wear the feet to a fare-you-well. Much has been said of the high-top hunting-boot being the father of blisters. A lot of this blister stuff is caused by a boot that does not fit in the first place, and most any shoe that does not fit will coax blisters. If you get a snug fit around the heel and around the instep, with enough space in front that the toes do not rub and wear, the hunting-boot should not cause any more blisters than any ordinary shoe. In ordering a boot, space should be allowed for two to three pairs of socks, as a snug fit over one pair of light socks will tighten the boot too much when you get agoing with the right amount of sockage on the trail.

One very important thing in the high-top boot is to keep the leather soft and pliable by rubbing them 
often with oil, and a boot so treated will not harden and become stiff.

I have a pair of sixteen-inch high-toppers of good heavy leather, yet they are as soft and pliable as a kid glove. This pair of high-toppers stand out as an example of what can be accomplished with a pair of hunting-boots that really fit the foot. This fall these boots were worn on a trip through the Rockies that covered 260 miles of hiking over trails, through timber and rough going found in the mountains. Through a period of twenty-one days, during which time they were worn, only one small blister was developed, and that one was immediately discouraged by the application of a small piece of adhesive tape. In the matter of socks worn with this pair of boots, one pair of closely woven woolen socks were next to the feet, and over these socks were drawn two pair of lumbermen's woolen socks. The start was originally made with one pair of lumberman's socks, but on the appearance of the first blister the other pair was added and no further trouble was had during the entire trip. Many streams were waded, but the fact that the boots were dubbed regularly made them keep the water on the outside, not only in the streams, but also through the snow and the hiking during the wet days.

What suits one fellow in the shoe line may be a Jonah to his pardner, and the one best bet in shoeing yourself is to select what is right and comfort- 
able on your own feet. Coming along about halfway between the light moccasins and the heavy hunting-boots we have a layout that about strikes the general average for most feet, in combining some of the fine feel of the moccasin and the protection of the high boot. This is the popular cruiser style of shoe-pac, or larrigan, as it is termed by the north woodsman. The larrigan is made of oiltanned leather shaped like a moc with the added value of a sole and heel which comes with tops all the way up to 8 inches. The sole is in a way flexible, and the larrigan is more pliable and softer on the feet than the ordinary shoe. The seams are on top where there is less strain, and as long as you keep them well oiled the shoe-pac is water-proof. For the wet swampy going that you will often find in the North Woods they are great, and as footgear for still-hunting they are fine medicine.

For the heavy boys in the clan, the larrigan is right; after trying out the moccasin without a sole and becoming friendly to its soft feel, but cussing it for the sore feeling to the under part of the feet, if the heavy-weights will slip their feet into a pair of larrigans, they will swear by that style shoe the balance of their out-door days.

The wearing of high-top boots or pacs seems to worry some people an awful lot, most of the advice being to get an eight or ten inch top and then wear a 
leggin with this size. I have never had any bother with the high-toppers, and on an ordinary trip of two or three weeks they will not be worn so steadily that they will cause any discomfort or foot trouble. Get 'em high enough to suit your own desires and why bother with a pair of leggins when you can get them right on the shoe or pac. If you are going to do a bit of hiking through burnt over or slashings with all the windfalls and small brush purposely blown in your path by the winds that be, you will find the high-tops mighty good protection without any of the openwork of the leggins in which to gather every upstanding snag in the timber. The main thing is to keep 'em soft and pliant and not get them any heavier than you feel that you can lift around in a day's going.

The big thing is to get good quality materials in your footwear; the best is what you should look for; get them a bit large to accommodate the pair of thin woolen socks and the extra pair of lumberman's socks; be sure and have them fit particularly close up to the instep and around the heel and to keep them in good shape, soft and pliant by working oil or grease well into the leather.

And as a safety first, carry along a little strip of adhesive tape to paste over the first blister, and, by the way, old-timer, don't cut the top of the blister to let out the water, but make a small incision right 
outside of the raised blister and work in under without breaking the skin. The water will come out and the top of the blister remain unbroken, to heal up quickly without rubbing sore. 


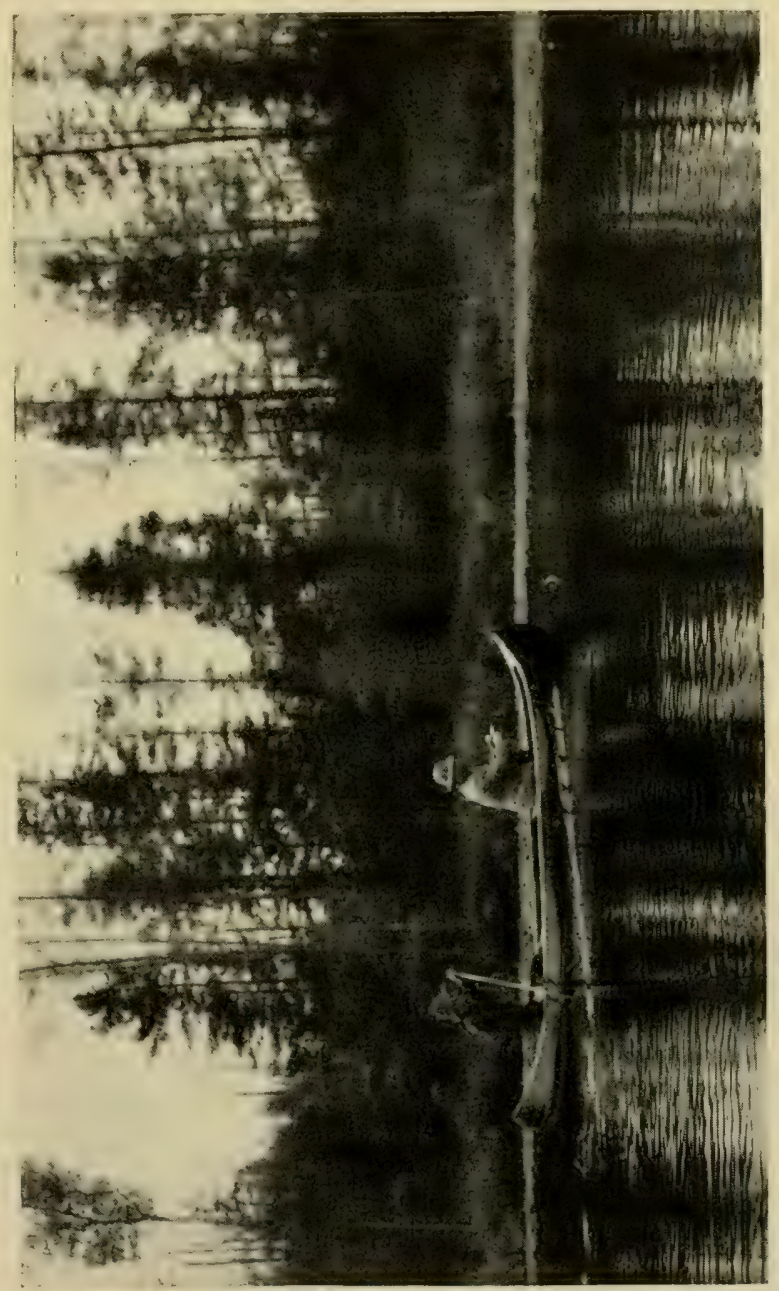

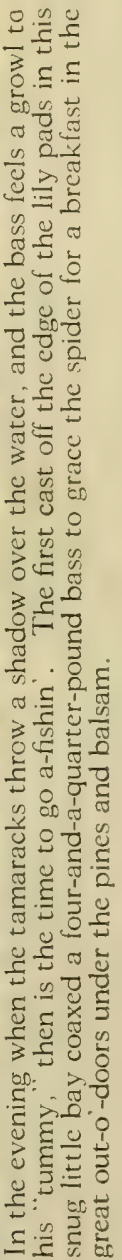





\section{A BIT ABOUT THE CAMP COMMISSARY}

OR KEEPING THE CITY RAISED “TUMMY" IN SHAPE WHILE OUTDOORS

When a fellow passes a good share of his life in the city, treating his stomach to a regular diet, slipping his feet under the table on schedule time each day, said stomach shapes up along regular lines of habit and acts accordingly. When the time comes along to hit the steel for the trip into the woods where camping is in order, the job of figuring out what to take along in the eating-line looms up big, and it is somewhat of a problem to dope out just what to carry.

There is one thing that the beginner at the camping stunt generally fails to take into consideration, and that is the wonderful appetite that comes creeping along about the second day of active living in the out-o'-doors. The first day most any kind of meals will satisfy, the change and excitement carrying one along; but the next morning the crisp, early morning air and the sniff of the bacon frying makes you feel like eating your head off; then after the hike or row and the more or less quick lunch of midday and the strenuous afternoon, say, boy! the evening 
meal jumps up strong and probably double the amount one figures on is dumped into the pots and pans to satiate the growlings of a hungry tummy. And it's great, this appetite we have developed, and it gets heavier every day. Often on my trips I have found it necessary to replenish my supplies before we have made half the stay we intended, due entirely to the nip and pep of the air, and the energy consumed by heavy work has raised the call of my stomach to a powerful yelp that must be satisfied. There is nothing as bad for camp comfort as an underfed stomach. A fellow in this condition is just naturally out of humor and will grouch around and grumble most of the time.

Some fellows pride themselves particularly on the fact that they go on a camping trip to rough it; I do not. When I go into the woods along the water trails anywhere, I want to be just as comfortable as I possibly can and I am not a "soft" bird either. I like to hit the hay on an air mattress, for the simple reason that if I sleep well, I can do so much more during the day and thus derive much more pleasure from the out-o'-doors. And I want to give my stomach a fair deal. I like to prepare good meals, have a bit of relish with them, and top the whole thing off with a dessert, and I find in doing this that I have no "tummy" troubles, and I don't have to carry a layout of indigestion tablets and pills along to keep this organ of my system shipshape. 
When a fellow has made many trips to the outlands he finds out two important things: One, that his kit should be made up of the best things that he can secure, in material and workmanship, and that these pieces of outfit must be selected for what they can do to keep him comfortable in the outlands. Second, that his camp commissary must be complete and that he must not expect to subsist throughout the trip on bacon, flapjacks, hard biscuits, and fish or game. Taking care of these two important features will make any trip anywhere a success and the joy of it long to be remembered.

Naturally, when a fellow breaks into his regular routine of living and goes back to the experiences of his ancestors of the early days, he changes his diet, his living conditions and, in fact, steps as it were into another plane, far removed from the greater part of his life. To bridge this gap and keep in shape there are many little things in the commissary line that can be carried along that will sort of act as conditioners, and these things should not be overlooked.

Letting the main part of the commissary slip back a few pages, we give sweets and sugar the onceover. Have you ever felt the craving desire for sugars when far in the outlands with no sugar in sight? This craving is due to the great amount of energy consumed in hike, row, portage, and the usual work of camp and trail. To the fellow who, as a 
rule, does not do much heavy work or exercise in the city, after a few days in camp this craving for sweets will be a torment. Carry along plenty of sugar, jam, preserved fruits, candy, and chocolate. Don't think that the other fellows will place you in the sissy class if your personal pack shows up a line of this stuff. About the third day you will have to stand guard over it to keep them away from these sweets if the regular food supply does not include such stuff. There is nothing that can take the place of a chocolate bar as an in-between pacifier when fishing or hiking. I always carry a couple bars because it is real food, will take away a thirst on the hike when no spring is in sight, and will enable you to stay out on the trail or water quite a bit longer if the game or fishing is good and your stomach is crying for a feed.

Great is the call for sweets in the woods, and there is nothing that can take their place. I recall a canoe trip a couple seasons ago when four of us started down a stream with no habitation for a bit over a hundred miles. The chap in charge of the commissary slipped up on his job, and we had two pounds of sugar for the outfit. This ran out on the third day, and we passed the fourth and fifth feeling the gnawing craving for anything with a sweet kick to it. With numerous portages, and long ones at that, we burned up our energy on high speed, 


\section{A BIT ABOUT THE CAMP COMMISSARY 267}

The eighth day, which happened to be mine at the "cookie" job, we struck the first cabin, that of a settler from Vermont, and great was the joy when I hit camp with a quart of maple syrup. We never waited to wet the sides of flap-jacks with the syrup, but drank the stuff from our kit cups. We stuck around there four days consuming a quart of syrup each day until the settler ran out of stock, and then paddled away feeling like fighting cocks.

The changed diet of the woods calls for more work on the part of the digestive organs, and often a fellow will experience an attack of indigestion far from medical help that has possibilities of developing into an acute stage which is bad business under such conditions. This is sometimes caused by the change of air, water, and heavy eating, and the stomach calls for a bit of roughage and the system an effective laxative. I have found that bran and grits will help out without falling back on the medicine kit and tone up your system at the same time. And the beauty of these natural foods is that you can take your medicine without knowing it. While mixing up a batch of flap-jacks or biscuits I put in about half a cup to a cup of table bran, which improves the flavor and acts in a perfectly natural way as a stimulant to the lower digestive tract, keeping you regular. For the morning chow that will stand by you for a heavy day's casting, paddling, or hiking, and 
give your stomach some roughage to give it a grind, Cresco Grits or Barley Crystals are well worth carrying along.

Dates in the small packages make a most effective conditioner, carry a high food value in small bulk. They are also of a natural laxative value and besides that they break up the monotony of the usual camp menu and give a little needed change that will taste mighty good to the camper. I prefer to carry the small package dates because they keep better, are fresh and sweet, and they pack well. Dried raisins also are a rather handy bit of diet, and a handful dropped in the pocket will be found great when far from camp, and with a long trail ahead before you reach the head camp, while dropping a few raisins into a batch of bran muffins tosses you right up to the seventh heaven of delight when you sink your teeth into them.

There is one thing that I never go into the woods without. I would just naturally leave my tackle at home as soon as cut this handy practical piece of commissary out of my grub and that is Anker's Beef Bouillon Capsules. For making the camp soup carry the taste of fresh meat, which by the way, is a delightful flavor after much bacon or ham, you simply drop a couple of these tablets into the pot and when you eat it you never forget the flavor. You can slip a little box in your pocket and always feel that you are safe from hunger if you happen to stray off 


\section{A BIT ABOUT THE CAMP COMMISSARY 269}

the trail. For the quick cup of good hot tasty stuff that will warm you up after a wet, cold hike, make you able to wait for the meal without having the south end of your stomach bite a hole in the north end, you cannot beat the beef bouillon by a long shot. All you need is a pot of hot water, drop a tablet into it, or if you like it stronger drop in two, give it a stir, and after you drink it, pass out a silent prayer of thanks to the wise bird who doped out the system of putting so much concentrated beef into so little a space, and still kept it sweet and tasty.

If you don't happen to have much taste for condiments, believe me, pal, when you pass through a week or so on the woods diet of fried this and fried that, you will wish, with all your wishing power, for a shot of ketchup, chili sauce, or anything with a biting kick to it, and probably also cuss a trifle because you failed to include something like this in your layout. The flavors you can add to your grub will give you a variety that will make your palate smile with joy, and changing the taste of the usual run of fried stuff with a dash of sharp tasting condiment will tone up the system; in fact, you need something just like Heinz India Relish to balance the system.

Which recalls to my mind a little experience. Last season I met a chap on the train going up to the north woods country. He was a likable fellow, and having no particular place to hit the timber, I in- 
vited him to fish at Timberedge Lodge with my pal and $\mathrm{I}$. We were going to stay five days on this trip, and I had buried way down in my pack twelve heads of lettuce to give us a bit of greens during the stay. Of course, to some fellows this may sound a trifle fastidious, but to have a nice dish of salad for the evening meal at your permanent camp in the north woods is what I call going it fine, and there is nothing that will taste better than this dash of green at the meal.

After the first day's fishing this chap told me he was head butler for one of the best-known millionaires of the country, so I decided to show him something different in the line of salad dressings. The salad in the woods fifteen miles from steel sort of had him panting at the starting-post, but the dressing made him sit up and smack his lips. As mixing salads with unpronounceable French and Italian names was his main job, he asked me for the recipe for this one. This passed the buck to me as I had put a dash of everything in the condiment line that I had at the cabin, into this dressing, thinking that a good kick to it would add zest to the appetite. I started with a half a cup of cider vinegar, added half a cup of Heinz ketchup, then a spoonful of dehydrated horse-radish, a pinch of paprika, a spoonful of mustard, salt and pepper to taste. This I beat up well with an egg-beater, then mixing up the yellows of three hard-boiled eggs with a cup of 
cream, I mixed the two together and again beat the stuff to a creamy froth with the egg-beater.

You can take it or leave it, old scout, this sure made a wonderful dressing, much to my surprise. If I had had anything else in the cabin in the condiment line I probably would have added it to the mixture, but since the carburetors of the human machines around the festive board seemed to appreciate the stuff, I am glad I left the rest out. Some six months later the butler chap told me that he was serving that darned dressing more than any other at the table of the multimillionaire he worked for, and that in order to camouflage it under a French name to avert suspicion of its lowly origin, he had named it "El Campo Dressing."

Looking over a number of trips last season, I find the list herewith tallies out for two pals on a two weeks' trip. The dope is taken from three trips made on streams along which few settlers were passed and no opportunities were had to buy vegetables or meats en route. This list, however, was varied and helped by fish and small game, and at the end of the trip an average of ten pounds of provisions was on hand. However, it is always better to go a bit over than short, as the appetite is a corker the second week. Then, again, fishing may not come up to expectations, and the game be scarce, which would mean that the left-over ten pounds would come in mighty handy. 
We start the list with bacon in strips, eight pounds; small ham or butt, five pounds; salt pork, two pounds; butter, four pounds; lard, one pound; egg powder, or desiccated eggs, one pound, equaling four dozen fresh eggs; milk powder, three pounds, equal to three gallons of milk; white flour, twelve pounds; cornmeal, one pound; prepared pancake flour, two pounds; rolled oats, one pound; rice, one pound; dehydro potatoes, riced, two pounds, equaling fourteen pounds of fresh potatoes, and one pound sliced, equaling seven pounds of fresh; dehydro carrots, one-fourth pound, equaling three pounds fresh; dehydro onions, one-fourth pound, equaling four pounds fresh; dehydro cranberries, one-fourth pound, equaling two and one-half quarts fresh fruit; dehydro raspberries, one-half pound, equaling five quarts fresh berries; dried beans, four pounds; prunes, one pound; dried peaches, one pound; raisins, one pound; sugar, six pounds; coffee, two pounds; tea, one-half pound; cocoa, one-half pound; salt, one pound; pepper, one ounce; baking powder, one-half pound; lemons, one-half dozen; mixed nut kernels, one pound; dates, candy, chocolate, and beef bouillon tablets, five pounds.

The above list runs about 64 pounds, or an average of 16 pounds a week, about two and one-third pounds per day, for each fellow, and when you add to this amount the fish and small game, your average will run about 3 pounds, which is all the boys from 
the walled-up cities builded by man can assimilate when flirting with Old Lady Outdoors. The army garrison ration allowance is four pounds two ounces per day, but the mess is given the privilege of varying the amount of staples by substituting luxuries in which it is deficient, thus cutting down the weight of the menu and giving it more variety.

To the general list a fellow usually has some one favorite in the grub line that tickles his particular palate, and this article should be included in the grub list. Condiments vary the taste of the ordinary foods and give a bit of spice to the sauces and gravies. A bottle of ketchup and one of Worcestershire sauce should be included, also a jar of mustard, the latter being a good medicine for the woods as well as a seasoner. These additions do not add greatly to the weight of the pack, but they give it a variety of taste that will be appreciated, especially about the middle of the second week, when the diet begins to assume a sameness. I have found that many of the Heinz varieties of foods, relishes and condiments make not only ideal food for the camp commissary, but they are real valuable as conditioners and toners up of the system while on the woods diet and over-feeding the enormous appetite developed in the open air. Their india relish, chili sauce, ketchup, mustard and cider vinegar can be used for making some of the finest relishes and salad dressings and they add that taste to your camp cook- 
ing that makes your stomach feel "at home" no matter how much grease you develop in your cooking. While a can of their baked beans is the quickest lunch you can make over the campfire, at the same time they are handy to take along on the hike from the head camp to nearby lakes for the noonday lunch.

The pack can be lightened a bit and the amount of space reduced a little by substituting prepared coffee and tabloid tea for the regular kind. It is just as good as the latter, and takes but a minute or so to prepare. In fact, for the quick, hot drink and for carrying on the hike these two prepared articles are hard to beat. 


\section{HEAD CAMP TALKS}

A FEW SHORT-ARM JOLTS FROM THE CAMP-FIRE PAGE OF THE NATIONAL SPORTSMAN MAGAZINE

As editor of the National Sportsman Magazine, it has been my keen pleasure to write to over a hundrew thousand sportsmen readers each month, and around the Head Camp Fire we have had some great times together. The fellow who follows the call of the out-o'-doors, is a live-wire, a clean-cut chap, who is full of red blood, quick on the trigger of his brain and an American clear through. Love of the outdoors, love of his country and flag dominate his thoughts and actions. Thus his every-day life along the paths of civilization reflects the clean spirit of nature and her goodness. It is indeed a pleasure to me to belong to this big clan of Americans who mean so much to our country.

During the past year some few of my Head Camp Talks in the National Sportsman have been commented upon and quoted throughout the country and the following selection may interest the sportsmen who believe in playing the game fair and keeping 275 
fishing on the up-kick so that it may be better in the years that follow, and who wish to lead their friends along the woods and water trails of the out-o'-doors so that they may taste of the pleasures which Mother Nature holds out to the pilgrim.

Way back in the dim and dusty past, when this great country of ours was in the making, our fore-

Out-o'-Doors, Man's

Greatest Preacher fathers slipped into the statutes a lot of laws that were certainly corkers. They took so much of the joy out of life that these self-same laws have been termed "Blue Laws" by the people of to-day, living under conditions so entirely different from those of our sober-faced forebears, who, at moments when they were not hustling like the very dickens to keep the scalp on top of their heads, were burning the "witches," of whom they lived in mortal dread.

In the early days Sunday was set aside as a day upon which no work or pleasure should be enjoyed. One sat around and hoped for the best, but did not dare look pleasant lest some one would hie him before the judge for breaking the law. The longfaced fellows were in the majority, and they sure put the skids under the joy o' living wherever they could get a neck hold. A fellow with a torpid liver assisted by a fair-to-middlin' dose of yellow-jaundice probably was the leader of the outfit. 
Springing from a line of old stock like this myself, and holding those sturdy pioneers in the highest regard, let it be far from me to appear frivolous. But these days of ours are a bit different from those days of theirs, and the present-day game of keeping the pesky ol' wolf from getting too darned well acquainted takes up about all of six days a week, which leaves just one on which many of us can get out into the land of out-o'-doors, to commune with nature and her children of the streams and woodland trails.

Which brings us down to the fact that one of these old joy-killing laws is still on the statutes of a number of states, and that is the law that one cannot hunt nor fish on Sunday. Last season a friend o' mine living in an Eastern state camped along a peaceful little lake. While teaching a pal casting on a Sunday, from a pier where no self-respecting game-fish would loaf his time away, and with no thought of catching a fish, being too keen a woodsman to expect such a happening from such a location, the friend was served with a warrant for breaking the law and a rustic justice of the peace slipped him a fine of fifty iron men and costs. And this regardless of the explanation of the situation and the statement that the friend was aware of the law and not trying to break it.

Fifty-nine dollars and forty cents because he was out in the open, breathing in the God-given fresh, sweet air of the out-o'-doors, chumming with Nature, 
cleansing the body and soul of the sordid things of the walled-up cities builded by man, through a close communion with the wonders that endured long before the advent of man and man-made laws.

Sunday is rightfully called the day of rest and all of us hold that day with due respect as the day we seem closer to the Great Architect of the Universe, who made the clean, beautiful outdoors for the children of the earth. Getting out among these wonders of nature cannot help but make of us better and cleaner men and citizens of our commonwealth and country, and if the stream or lakes call us let us go forth rod in hand, if that helps us enjoy the rippling waters, or a gun if we answer to the enticing whisper of the woodland trails; let us take these things with us that we may get the most out of the many pleasures offered us by Dame Nature.

Fellows of the rod and gun, brothers of the outland trails, men of quiet camp-fires, hear me now you all who know the whisper of the wind as it soughs through the pine, the laughing voice of the fast-running stream waters, the quiet murmur of the placid lake as the waves kiss the moonbeams sent down from the blue-bowled starlit dome above, the deep silence of the nightlands of the out-o'-doors, ye are the chosen children within whose being beats the heart that is true and from within come thoughts that are pure and golden.

No man can commune with nature without being 
bettered thereby, no man can view the wonderful work of the Great Architect without a keener understanding of His greatness. The out-o'-doors is the greatest church in the whole world, and it preaches a sermon to every man every time he has a chance to sit right up in the front row. The follower of the call of the outlands is a man every time and true blue. $\mathrm{He}$ is on the square and can look you in the eye without dropping the lids. Far more do we trust him than some of the sleek, squinty-eyed gentry who wear a small halo around their dome in public and who stick the knife into your back when you are not looking; who would not fish on Sunday for anything, but who would likely do about everything else in the deck if no one were looking.

Let my prayer be always that my friends may be from the ranks of the fellows who know the yearning call of the red gods, from the ranks of the fellows who sneak away every chance they get to whip a stream or hike afield, fellows who give you the glad hand of true friendship with a grip that you feel and know is coming from the heart.

In the meantime it is right and just that a fellow who grinds away six days at his work should have the week-end for a visit in the out-o'-doors, and every one of us should get busy at once for a repeal of the law against fishing and hunting on Sunday which is on the statutes of some states. Nothing can be accomplished by sitting back and twiddling 
our thumbs, nobody else is going to do the work for us, we have simply got to put the shoulder to the wheel and push,- - everybody push hard, - and the best way this can be carried on is through the work of state sportsmen's associations and leagues.

Start the good work now,- get in touch with your association and plug for what is right and just to the men who are keen enough to enjoy the God-given pleasures of the great out-o'-doors.

To-day, as I write this, my heart is heavy. I have just received word from a hunting friend that Thomas Bodkin is dead.

Do You Close the Bars and Shut the Gates?

$\mathrm{He}$ has answered the call, and a true heart has beat its last kindly throb. Thomas Bodkin was a farmer, a tiller of the soil, one of nature's own flock, a veteran of the Civil War and a fine man. But what made him famous was his friendship for the hunters. About ten years ago he had posted on his farm a sign as follows: "Autoists, hunt all you please on my farm, be careful of the livestock, and you are welcome to the house for dinner." I recall a pleasant chat with Bodkin a number of years ago while hunting in Indiana, as we sat in the cool shade of a great old tree after a day's hunt. This sign had been respected by all hunters, never had Bodkin any 
cause for complaint, and he had made many friends through this so-different posting of a farm. He had merely put it up to the hunters, and they were on their honor to respect the kindness of this grand old man.

At times a fellow will be forgetful in the excitement of the chase and let down the bars and leave them down or go through a gate and leave it open with the result that livestock wanders in among the corn or cabbages and cuts up considerable damage. Such forgetfulness naturally makes the farmers sore and up goes the usual notice of "No Trespassing This Means Hunters Keep Off." Fellows, we'll have more open hunting-grounds if we stop to think a moment and close the gate.

Here's the best of everything to Thomas Bodkin in the happy hunting-grounds, friend to the hunter and the hunter his friend. They never left his bars down or his gate open.

Right about now is a good time to think about restocking the nearby lakes and streams; no, I stand

The Early Birdie

Gets the Fat Worms corrected, it is time to get busy and call the local fishing clan together and form a committee of the "Brothers of the Angle" of your neighborhood, whose duty it will be to take up the 
matter with your state department of hunting and fishing and find out how many fry or fingerling of the game fish-tribes you can have for your waters.

Nearly every state is willing to furnish the stocking fish if they are sure the cans of fingerlings will be taken immediately on arrival at the station and dumped in the waters to be stocked. And to keep the great sport of fishing on the up-kick, the sportsmen of every community that has suitable waters for stocking should get together and do the job right through. A small committee can handle all the details of the work and handle them right, not only to the satisfaction of the rest of the local rodwielders, but to the satisfaction of the state officials, who are always glad to cooperate with a representative committee from any community within their commonwealth.

Just stop and think for a minute - perhaps fishing in your waters was not quite up to snuff last season, the same old he-wops do not seem to be kicking around thereabouts. You need a little stocking, oldtimer, something to keep the average up, you know ; same old game, taking everything away and puttin' nothing back sets the pile of chips down to nix plus. Try putting in a few canfuls of young fish each season for five years and you will be surprised how much better the fishing is than it ever was before. Now is the time to do the organizing, and placing your request now for fingerlings or fry may mean that 
you get yours before the available supply hits the low-water mark. You know the story about the early bird and the worm-BE THE EARLY BIRDIE.

This little old talk is mainly for us married fellows, but at the same time it will not hurt any of the " singles" to sit in and get

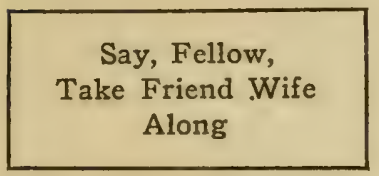

a bit of dope for future use. You never can tell how soon one of the fair sex may come along and slip the double hitch over you, and a little friendly advice from one of the tandem outfit may help smooth the kinks out of the road later, for kinks are bound to slip in more or less, some little, some great, with all of us.

One who goes into the hinterlands along the trails of stream or field, close to nature, probably driven by an impulse or instinct coming down from ancestors of the early days of the country, desires at all times to be sure of his pal on these trips back to the primitive. A pal that is right means much on a trip - it will either be a rattling success or a disgruntled failure, due entirely as to how you two hitch. A pal who is agreeable, likable, and willing to do his share, and even a bit more, makes the trip a joy from the start and one to be made again many 
times in memory in later years. Is there any one, old-timer, who would make a better pal than friend wife?

Mrs. Dixie has been hitting the woods and water trails with yours truly for quite some years, and say, fellows, on the quiet, she is right at home on the trail, in the camp, on the lake or stream. And ghee, how she loves the outdoors, the birds, the squirrels, the whole deck of forest children! Why, man, you are missing half the pleasures of life by forgetting to take the wife along - make a woodsman out of her and give her a chance to enjoy these same pleasures that give you pep and health. Let her breathe the balsam-scented air of the northlands, see nature working overtime on the wonders of the out-o'-doors. After one trip you'll have a steady pal for life on your trips, and you probably will kick yourself around in circles because you overlooked this bet in the past.

Of course, you will have to do a bit more on the carry, take a little more of the work about the camp, but you'll never find a more willing pupil, and they take to the outdoors like a duck to water. It won't be long before you will be looking to your laurels in the game of matching wits with a keen brain that you likely did not entirely credit her with before.

I have a sort of an idea that more outdoors for the real boss of the family would mean less family troubles in many cases and at the same time be a 
wonderful thing for the health of the gentler sex. There never has been an elixir of youth compared to the early rising with the sun, the cool dip in the lake or running stream, which is generally a darned sight colder, the early morning row or paddle to the home of the bass or musky, the hike over portage. Old Ponce de Leon sure was on the wrong trail way back there in the fifteenth century when he kicked around looking for a spring as the elixir o' youth. What he should have had his eye pealed for was a fishing stream or any kind of outdoor trail. So take her along, old man, and the woods will take on a brighter hue, the aroma of coffee and bacon from the evening camp-fire will have a homey touch, and every little thing will be more worth while - but do your share and a bit more of the work. 'Tis a great life in the outdoors, let the better half share its pleasures.

Way back when I was a kid, satisfied with a bent pin and a stretch of string as a tackle outfit and a

By Heck, How

Times Have

Changed, la-la!

few sunnies or suckers as

the results of following the banks of the home creek, the fellows who generally spent their time going afishing were usually called the village loafers; they just sort of drifted into going down to the dam and 
loafing away their time with a long cane pole and a can of worms. A lot of people shook their heads and hoped for the best, but decided that there wasn't much use a-hoping, as these birds would likely just loaf along and not amount to a row of pins. Fact is, the fisherman certainly did not stand ace high with a majority of the local high-brows and ethically he was nix plus with the solid, hard-working gentry.

I thank the Great Master for these old-time fishermen; it was from some of them that I first received my love for the outdoors, for the limpid lake, the bubbling stream, the woodland trail, and all of nature. Many were the warm afternoons, stolen from my books and studies, that were passed with these old "young" fellows, and much have I to thank them for. Great was their knowledge of fins, furs, and feathers; they knew where the crappies lived, where to get the biggest sunnies and bass; say, they knew every little kink in the bassing game. 'Course they did not know much about tackle as it is to-day, but they certainly knew fish and fishing, and that is something that every angler must know to really enjoy the pleasures of lake and stream.

How times have changed! Who are the fishermen of to-day? They come from every walk of life. They are the life of our fair land. You are just as likely to see the president of a bank out a-fish- 
ing to-day as you are to see the freckled-faced kid who dusts his chair. In fact, more so. The more one has developed the brain he possesses, the keener he is to give that brain the benefit of a few weeks out in the clean air of the out-o'-doors. We, of the angling brotherhood, come from the palace and the hovel, but regardless of our source of entry into the game, nature gives to all of us the same opportunity to derive the same pleasures from the great sport. It is our own actions along lake and stream which govern the joy and pleasure we derive therefrom. We can drink deep of the nectar or simply skim over the top.

Just to show the change in say thirty years in the makeup of a crowd of men who go a-fishing now and to the makeup of the earlier days I made a few notes while browsing over fishing and such on a trip to the north woods early this season. To my left, in the smoker, sat the auditor of one of the largest of our railroads, and discussing with him on the attractiveness of the mud-minnow as a bait for wall-eyed pike was the owner of a delicatessen store, and the argument waxed warm and fluent. Across the seat were two men deep in the value of a single or tandem spoon and what the red had to do with making a piece of pork rind more interesting to the bass. One was a "hoss" doctor from a small town in a prairie state and the other happened to be the owner 
of one of the largest mail-order houses in the world, while right behind these chaps were five men deep in the subject of fishing lore in general - a doctor, a shoe salesman, a plumber, a butcher, and a politician, all passing out the information they thought would help the other fellow to better his average.

When you get down to the brass tacks you know that the men who make up the real citizenry of the land follow the call of the lake and stream and that going a-fishing to-day means that one is enjoying the cleanest of sports. No more does the high brow lift the eye-brows when the fisherman goes past, - not on your life; he hustles home and gets the tackle and kicks along, because he has a sneaking idea that they may be biting and that he will miss something if he don't hurry. For a long time they were missing something and did not know it.

Yep, we got a lot to thank the old-timer for; he just kept on fishing regardless of what the other fellow thought and taught the rest of the outfit there was something in the fishing game. There was a reason for his good nature, his always smiling face and his good health, and at last it dawned upon the other fellow that it must be the fishing - therefore the great and eager throng who each year shine up the tackle, hit the trail, and enjoy life because they have made the great discovery. May our fishin' days be long and our actions on lake and stream those of the true sportsman. 
You never can tell when some little old thing you have learned as a sport or pleasure will come in

Pleasures of Sports Pay a Big Dividend handy at the right moment to help put across the vital part of the big game of life. There are still a few drudges of the ordinary work-a-day world who think the time a fellow gives to sport, and especially the great sport of the rod and gun, lake, stream, or trail, is a waste of time, a woful waste of time, brothers, time that these self-same drudges grind out a few more paltry dollars to leave behind when they pass on over the long trail. Of course, we all know that following the call of the outdoors gives us health as well as pleasure, but here is a little tale of how the knowledge gained from following the "call" helped save the day for a bunch of the boys on the battle-front in France.

Charley Klein, of Brooklyn, one of the knights of the out-o'-doors clan, put in his week-ends hitting up the highways to his favorite pools and streams on his modern steed, the motor-cycle, and while enjoying the exhilarating pleasure of speeding along the country roads in the nippy morning air, he learned the motor-cycle game almost as well as a race-driver. He could take her apart, make a repair, do the roughest roads and never "pull leather." With him it was entirely a sporting proposition, that little element in the game which makes us Americans able 
to do things on the spur of the moment, when some other nationalities have to sit down and think it over.

Skipping along to the war, we find Charley "joined up" early, and after going through the paces he is doing his bit over there with his pals; and doing this bit, fellows, where the shells are raising merry hell on the front line, along the Marne.

During the general mix-up, the Boches slip over a box barrage and cut off quite a bit of the line, and it looks like the finish to the outfit. Everything depends upon getting word back to the artillery for a counter-barrage. Three couriers make a running start, but are cut down by the shrapnel, when, by chance, Charley Klein discovers a motor-cycle belonging to a staff courier who has been badly wounded on the way up to the front. Sure you get me, oldtimers, it only took Klein a few moments to tell the C. O. that he could ride 'er and that he would be tickled to give it a shot through the bad lands.

So he gave it a bit of gas, opened her up, and away whisked an American sportsman, with as much sangfroid as though he were speeding along the pikes of Westchester County, New York. Carrying the message that meant life or death to his pals - and able to do it at the right time because he was one of the clan of the outdoor trails.

And he delivered the message - certainly, although he had " put on full steam until the old mo- 
tor-cycle leaped some of the shell-holes like a kangaroo," as Charley said when he woke up in the hospital. And then, because of his smile and quaint humor in the hospital, Klein was nicknamed "Sunny Charles."

I'm for Charley Klein, both ways from the jack, and every one of the many, many Charley Kleins we have around us every day of our ordinary old life. The Charley Kleins are the fellows who love the out-o'-doors, who know the voices of nature's children, the ripple of the falling water as the bass makes its leap into the air, the purr of the motor-cycle as it carries us along our way, the muffled drum of the partridge as he makes music with his wings, the "honk, honk," of the flying squadrons of the air, the "putt, putt, putt," of the motor as it drives our boat through the laughing waves. Of such thoughts men are made. Give me, always for my close friends, those who love the voices of the outlands. Such friends are the ones that can be depended upon as being there with the wallop at the right time, and they never bat an eye, no matter what is to be done, and every time, fellows, you will find that some little thing they have learned from the great teacher of the outdoors will stand them in good stead and they are able to do that which they are called upon to perform.

Of course, a few of the great clan get a chance like Charley Klein to come through with a big chance that 
means so much to so many; but it is a pleasing thought to feel that the citizenry of one's country is made up of a great army of men who are able to stand up and say, "I will deliver the message!" and then know that they will be able to do it.

Every outdoor man is a teacher. He spreads the gospel of the waters and trails among the many men who grind through life without the light of the wonderlands of nature, and if but one convert is made, the work is well done. A little seed of thought of the joys of the outlands may bring to the nostrils of the city-weary chap the scent of the pines, the aroma of the evening camp-fire, not to mention the browning bacon; and after one trip to the woods, you generally have a regular visitor, who never will be able to thank you for bringing him into the walks that are yours and the ways that are wonderful. Brother, be a missionary.

As I write this, I have before me a letter that brings back memories of by-gone days, when, as

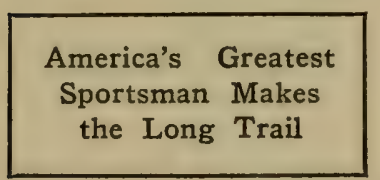
late Colonel Roosevelt when he was out cutting up for a few weeks in covering the "summer White House" at Oyster Bay. Here, one day, I met the

a cub reporter, I assisted 
a tree to keep in shape for the strenuous work of running our country. I had the pleasure of a mighty fine talk on the out-o'-doors with Colonel Roosevelt, and found him intensely interested in the protection of our game and fish, and his knowledge of the subject showed that he had a wonderful insight into every angle of the "how, when, and why" of protecting these children of the forest, field, lake, and stream. And he was for protection strong.

With his passing, America, in fact, the whole world, loses its most powerful and strenuous advocate of the out-o'-doors sports, nature's own heritage, and given us to enjoy if we treat it right.

Although ill-health originally turned Roosevelt as a young man to the outdoors, long before his advent into the Western country he had made a thorough study of natural history in all its phases. Much of this love of the outlands no doubt came from his association with his uncle, Robert B. Roosevelt, author of "Superior Fishing " and other works on hunting and the outdoors, with whom young Roosevelt studied law.

Colonel Roosevelt was a true sportsman, and sets an example that any fellow can follow, knowing that he can find no cleaner ideal of true sportsmanship than that after which he patterns his actions on lake, stream, or woodland trail. He was a great naturalist, a keen hunter, and an active conservationist, and his good influence on matters pertaining 
to the conserving of our fish and game will live long after his passing.

Great as has been his work in other lines, so much greater has been the good he has.accomplished in matters dear to the heart of the sportsman, and had he never entered the political life of the country, he would still have left behind a wonderful record of achievement as a naturalist, writer, and protector of nature's children.

May we all find pleasure in following his teachings along the out-o'-doors trails, that his good work along this line may not fall by the wayside, nor the storehouse of nature be denuded of the good things of life.

Say, fellows of the out-o'-doors clan, do you ever hunch back in the old easy-chair and let your memory

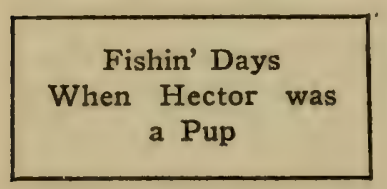
carry you back to the days of the past when you were a barefoot kid toting one of those long ol' cane poles or one of the elders cut à la natural from the bankside? You probably recall with joy many fishin' trips with the kid pals of those days, the first big pickerel you landed, and ghee! how proud you were when you showed him to the grown-folks! And then the first time you connected up with a bass, how he made the long pole double 
up and the scary jumps shoot up along your backbone, and how in the excitement you gave the pole a swish and landed the game-one way back on the bank where you pounced upon him for safety before he flopped back into the water! And the deep pool shaded by the trim old sycamore with the fringe of willows where you could hide and watch the bass as they took their feed with a swirl from the surface. Those were the days, and lucky the fellow who can let his thoughts wander back to such a happy childhood.

Last winter memories of other days came back to me many times, memories of fishin' trips with youths of other days, some of whom now sleep in France and Flanders. I recalled the favorite creek which has its source in the Alleghany Mountains and tumbles and rolls into the headwaters of the Potomac, and in my youthful days as good a bass stream as you could find in many a day; the old milldam, where the big ones lived, and how we would toss the small frogs in and watch the bass come up and grab 'em off the top, later to slip one on the hook and snap it out in the water, and from our hidden spot behind the spice-wood bushes fight the overzealous bass via the fourteen-foot cane-pole route; old Blue-stone Hole, where the small-mouth held sway, and where we would let our minnows swim down around the edges of the huge blue rocks that jutted out of the deep waters; then a little later the 
long stretch of fairly fast water, broken here and there with riffs and white water and pools and such, just what any good stretch of wading water should be and all of two miles until you hit the big pool close to the Devil's Slide, where the creek cut through the mountains at the Narrows; and along the whole stream a big old frowning mountain throwing its shadows down over the pools just where they would do the most good.

An ideal stream was this bubbling, rushing water of my kiddie days, and the memories were so strong that I dropped off there to meet a few of the old "he-wop" bass that had grown up since I had migrated to many other waters. The stream was there, the same old holes, the mill-dam a bit more delapidated but still on the job, the rushing, tumbling stretch of the finest fly-casting water - everything, in fact, looked fish, but not a bass to greet me. I fished that stream every way from the jack, fished it as it had never been fished before without a strike. Had a lot of fun, of course, which is natural to the angler whether he lands the game-fin or not, but I sure was sore that such an excellent piece of water should be shot to helengone.

Here was a stream that was a natural breedingplace for the bass and one that I did not think could ever be fished out, a place that a fellow could come back to any old time and have a few days' pleasure. All of this spoiled because a law had not been en- 
forced, a law on the statutes of that state against the pollution of streams. A tannery having located some ten miles up this stream had so filled it with acids that no self-respecting game-fish could live in it, and probably those that had not died had tailed away in disgust.

Nearly every state has laws covering the pollution of streams, but it seems that in most cases these laws are merely jokers, as many streams that were once fine fishing-waters have become so poisoned that fish cannot live in them, and thus another source of nature's bounty to her peoples has been taken away from them.

Naturally we must have our factories, our manufacturing plants; they are the life of the country; but a little forethought and expenditure on their part would eliminate the pollution of the streams along which they are located. In the great old grab for money - in the rush to get the wandering dollar corralled before some one else nabs it - nature is given walloping jolts below the belt every day, to the loss of the people who love the out-o'doors. It is interesting to note from time to time that local sportsmen's associations are going after the stream polluter, and this work should be carried on until the plants causing the poisoning of streams have put in improvements in the way of filtration systems that will eliminate this curse of our natural resources. 
Think how glad the bass are to raise a large family, how tickled the wall-eyed pike to breed her thousands each year, and yet we take away from them their happy family waters! - not to forget the great good it does us all to get out along the stream if only for a day or for a week or two, as our luck happens to be. If the streams in your locality are getting the worst of it, old-timer, get together with a few of the brothers of the angle and start things moving to clean 'em up. You may not be able to accomplish much the first season, but thought will have been centered on your efforts, which will grow until the good work is finished.

This is a little old Head-Camp Talk that you have not been looking for; it just sort of slipped in between some of those for

Dillon Cobine,

Angler, Trapper age fourteen the grown-up boys of the campfire. I have entrusted your Uncle Sam with a little package which

I hope will bring as bright a gleam to your eyes as the pleasure it gave me in sending it to you. You see, Dil, I'm only sort of a grown-up boy myself and every now and then I think of the days when I was a kid and what a joy jump of happiness came over me when I was handed a piece of tackle, not to forget the choking lump in the throat and the desire to 
just sit down and bust a few tear ducts because of this self-same happiness. And listen close, boy, there are a lot of old-timers at the outdoors game who get this same feeling right now when they slip back in memory to the days along the home-town creeks and lakes.

Son, when you fondle this tackle, if you are like the most of us boys, you will have an overwhelming desire to go out and match your wits with the wile of the game fish - that's just natural, boy, and comes to us from way back in the Stone Age when the natives, our ancestors, coaxed the big fins out of the wet with a carved bone for a hook. Of course those old-timers at the game were not sportsmen; they yanked the fish out in order to change their diet, and the diet in those days was so slim that a change was due them, but right now in this age of movies, patent breakfast foods and flivvers there is no excuse for a fisherman to derrick 'em out of their home waters - play them right, according to the rules of the game and you'll have many a pleasant day on lake and stream.

As the rod bends in your hand from the pull of a bass and arches into a beautiful curve you will feel the same jumps go racing up your spine that you do now when some of the victorious Yanks go marching by, or when the bands strike up the Star Spangled Banner, and your nerves will tingle from the heat of battle - and glory be, when he makes his first 
break out of the water you will feel like a Comanche Indian doing a hoe-down. That's the red blood in your veins hopping to the fore, and when you finally bring the game one to net, you will feel like doffing the lid to the gamest of the game.

Once you get the fever, boy, and you hit the steel for the quiet places, just far enough from civilization to be out of touch with the walled-up cities builded by man, you will then get a close-up of old Mother Nature that will give you a keener insight into what a wonderful place this little earth really is, and it will instill within you a desire for greater and grander things than the trails of civilized life could ever give you. And each year you will feel this call stronger - it will become a part of your life to make a pilgrimage to the outlands to breathe the balsam-scented air as you hike along the woodland trails or paddle along the waterways in your quest of the Golden Fleece.

And many a battle you'll fight on the water, that will come back to you in pleasant memories during the off-season when the snow drives you into your burrow - the aroma of the woodsy campfire and the whiff of the cooking will come back to you and you will enjoy again the pleasures of the great outdoors to the accompanying whistle of the steam radiator and the honk of a passing motor. For downright fun, kid, it has the other games pawing the ground at the starting post, and maybe, after you 
have passed along in the sport, you will discover things in it that some of the other fellows have overlooked, and thus be able to add to the pleasures of the fellows who follow you.

I am sending you a copy of "Lake and Stream Game Fishing," one of my humble efforts to help the other fellow in his quest of the game fish, and while you are in the first stages of the fishing fever, you can whet your appetite on what's between its covers. I hope it will bring to your heart the call of the great outdoors, the whisper of the tall pines and the laughing gurgle of the rushing waters, the flash of the dying sun on the quiet lake waters, the call of the loon as the moon shoots down its beams on a silence far greater than you have ever experienced in the walks of civilization.

I am not going to load you up with advice, boy; everybody seems to have a bit of that to shuffle out on the least provocation, but I want you and all of the young sportsmen to follow the creed of the American Anglers' League when you answer the yelp of the red-gods and make your forays on the game fins. This is the creed and it should be your creed: To observe all fishing laws; to throw back uninjured the undersized fish; to advocate the restocking of lakes and streams and to catch game fish in a sportsmanlike manner with rod, line and reel so that the fishing may be better in the days to come.

Perhaps, some time in the distant future, when I 
am cultivating a fluffy white beard and just hanging around my cabin waiting for the last portage over the long trail, you can ease up the quiet days of us old-timers with stories of the outlands, the camp, trails, lakes and streams, for which memory trips we will thank you. It is the young sportsmen who will have to take up the work of the old-timers and keep the joys and pleasures of the outdoors fresh in the thoughts of all so that its followers may become legion.

Each year, we of the out-o'-doors clan see the interest in nature's sports grow keener, more fellows, Hunting and Fishing License Money
How about the and the ladies too, are answering the great call and becoming regulars along the lake, stream, woods and trail. This is well, it means a finer, cleaner citizenry and a healthier, more free from care, unworried people. The state lawmakers are beginning to take heed of the sportsman as an important factor in the commonwealth and it is certainly up to the state sportsmen's organizations to see that the lawmakers give them a just and square deal. All the unwritten laws of sportsmanship call for a square deal for the game. Sportsmanship in itself is nothing else than uphold- 
ing the laws of man and the laws of one's conscience, and the laws of a state governing the game and fish should be based upon a square deal to the sportsman, which is just and due him.

All states have a license covering game, and each year we see more of them adopting the fishing license, which in itself is right, as both game and fish have mostly in the past been supported by a license paid by the gunner. No sportsman, whether angler or gunner, objects to paying this tax to protect and perpetuate his line of sport, if he knows that the moneys so paid are used for that purpose, but it certainly leaves a bit of a sore spot to have these moneys diverted to other lines of state welfare.

It is often the case that a state will switch a big chunk of the money received from hunting and fishing licenses to some entirely different and foreign fund, while some states do not even have a special hunting and fishing fund, the money derived from this source going into the general state fund, and then when the game and fish department needs money it must waste all kinds of time and effort trying to get a special appropriation through the legislature in order to half-heartedly carry on the work of making hunting and fishing better. And at such times there is generally such a yip goes up from the stiff-collared gentry who do not hunt or fish, about wasting the state funds for such foolishness, that the game and fish commissioner is lucky to get a fund of half what 
he asked for. These "never-goers" seem to forget entirely that the sportsmen themselves have paid in license money much more than the amount generally asked for.

This condition is entirely wrong. Every cent of license money paid in by the hunter and fisherman should be spent to make better the hunting and fishing of that state. Every sportsman in a state where the money from the hunting and fishing licenses is being diverted to other channels should take the firm stand that this money should go to building up the game and fish of that state and not jockeyed into building roads or some other state effort, to the loss of the outdoor sports given us by nature. What's the use of having a fine road to speed along to the lake or stream when you only find a few carp, suckers, bullheads or dogfish to yank into the boat, or a nice stretch of bird country with nary a bird to flush? Give us more hatcheries, more game farms, and if there is any of our money left over, put it into a reserve fund; we may need it the following year if the cold weather happens to kill off the game or an epidemic lay the game fish low.

There are too many political ways to slip the kibosh to a fund, to let the matter rest as it is, and in states where the game and fish department is not getting a square deal, every sportsman should join with a movement to clean things up. See just what the conditions really are in your state - if they 
need a little cleaning, go to it, and stick to the job until your sport secures its rights. Continued effort and work along this line is the only thing that will bring results, and it sure will bring 'em if you go after them and keep pounding away.

In the meantime, it would not be a bad idea at all to have the fish and game department entirely divorced from politics. The best man in the state on game and fish is the man who should carry on the work of this department, and he should be given a free hand to do what he thinks is right to make hunting and fishing conditions better. Too much politics is a bad thing to have mixed up with any state department, but it sure can make a rotten mess of a fish and game department. Give the job to a man who is fitted for such work and the results will be wonderful; give it to a ward heeler and he will make a farce of it in no time.

Remember the key to successfully advancing your fish and game department in the right direction, if it needs it, is through organization. Very little can be accomplished alone - it takes the work of the banded together sportsmen of a state to make their strength felt down where it does the most good. Crowd together and make 'em feel your punch.

Every now and then some one raises the cry that we should get rid of the dogs - that the dog is 
not worth while anyway and that they are a needless

Our Dogs Here's to 'Em economic waste. Taking up the cry comes the wool grower and the textile manufacturers, loudly blaming the stray dog for killing sheep and thus reducing the almost invisible wool supply and trying to harness upon the dog the reason for the exorbitant high prices for the almost woolen clothing. A dog's a dog to these fellows, and because a semi-wild stray pirate of the dog tribe breaks over the line occasionally, they are strong for exterminating this greatest friend of mankind.

Along about this time we find some of the gunners coming out with the dope that by eliminating the bird dog from the game and slipping the leash to the beagle hound that the game birds and rabbits would multiply and hunting be better. The idea is wrong from the starting post - taking the bird dog out of the game would not help to increase the present supply and it certainly would lower the high degree of sportsmanship now so prevalent among bird hunters. As a class the keen fellows who follow the dog afield are clean sportsmen; they are not pot hunters nor game hogs, but fellows who take as much enjoyment from the fine work of their dogs as they do by coming in with a well-filled game bag. To shoot over dogs lends to the making of a cleaner sportsman, and I venture to say that few if any true follow- 
ers of the dog afield would be guilty of an unsportsmanlike act.

What about the dog's point of view? Have you ever noticed the dash and pep to a real bird dog when you go out among the feathers, the real enjoyment of your four-footed friend as he trots along at your side? Say, fellows, all you have to do to start something is to take the old gun down out of the rack and look 'er over to get a wag out of the tail and a gleam to your dog's eyes. They are in the game from the kick-off, and the fellow who loves a dog is loved by his dog. There is no truer friendship from animals than that which a dog gives to his master, and to have the true friendship of a dog means that one must be a fairly decent sort of a chap. The dog is an intelligent animal and he well knows the man who treats him kindly and right, and to such a man he will stick till the cows come home, and fight for him at that.

Have you ever noticed the instinct of the dog in picking his friends, and by the way, I bank a lot on how my dogs receive the fellows who go afield with me. Keep your weather eye peeled for the fellow who doesn't like dogs and take a good look at the fellow that your dog doesn't take to. I haven't much use for a fellow who will kick a dog, and I prize more highly the confidential wag of the tail of my favorite hunting dog than some of the "bull " shot by some humans. 
No, taking the dog out of the bird game will not make hunting better, nor will it raise the ideals of sportsmanship. I think a heap of the fellow who can come into camp with not overfilled game pockets, after following his dog, and then tell you what dandy sport he had watching his old pal do a cunning bit of field work, and to top off such a day, this same chap will see that his dog has a good feed and a place to curl up for the night before he attends to his own personal wants, - little things that in my mind show true sportsmanship.

Let us keep the dog with us, man's most loyal and unselfish friend among the animals, with the hope that he will help make the call afield strong in the hearts of all sportsmen.

The time is near when many of us will hike out into the hinterlands for the annual big time in the

The Annual Pilgrimage to the Great Outdoors woods, along the lakes and streams, into the Land of Heart's Desire, the great outdoors, there to commune with the red gods, to imbibe the nectar of the spirits of the outlands; in other words, hit the steel for our favorite camping-grounds, to wade the stream we love and whip the placid lake of our fancy. 
Many times during the past winter we have doped out the trip, planned the details, inspected the outfit, replaced parts of the kit, and added things that we decided would increase the comfort and pleasures of the jaunt. And keen has been the enjoyment of sitting back in the favorite easy-chair with the pals discussing all these details, not to forget recalling the striking incidents of last season's adventure. In fact, such little campfire talks have helped us to pass through the winter until nature brings the sniff of springtime into the air to stir our blood with the call of the out-o'doors.

Fellows, here is the sad part of the story. Advice is about the cheapest thing we find in the present days of combating the High Cost of Living. Everybody seems to be chuck full of advice and mighty willing to give it away at the first opportunity, - in fact, they more than meet one halfway, often hunting up the chance to spill a few yards of this great free commodity, but as to the line I give you here, all sportsmen will follow it because it means helping to save the out-doors and its wonders for us all as well as for those who follow in our trails in the future, after we have passed on to the Happy HuntingGrounds, just over the long portage.

My little chunk of advice is simply this, "Be sure and put out your camp-fire," which does not seem like an awful lot to ask of a fellow, when we figure 
that it is such a small thing to do. Yet each year, through carelessness in this "little thing," many millions of dollars in value are lost, many lives are snuffed out, and many square miles of forest are destroyed, which means that much game is killed and this same land is denuded of life and beauty.

A big part of this loss can be averted by every fellow who goes into the woods country making sure that his camp-fires are always completely extinguished. Many times the camp-fire is built over ground deep with the dry rot of years and this mat of dried leaves, limbs, roots, and grasses will smolder for hours, the first wind fanning it into a flame which starts the forest fire on its wild course of destruction. As a safety-first, clear off a location for your camp-fire, then be absolutely sure it is completely outened before you hit the trail for other places. And traveling right alongside of the "half-put-out" camp-fire are his pals. These little members of the Don't Family are just as destructive in their devilishness. They are: "Don't throw a match away after lighting your pipe," be sure it is dead before you drop it, and "Don't toss a lighted cigarette or cigar butt alongside the trail," unless it is entirely outened; not to forget that it is not good style in the woods to kick the heel of your lightened pipe on the edge of a log or tree to start a little personally conducted fire of its own - the darned fire might catch up to you anyway, they sure travel with speed 


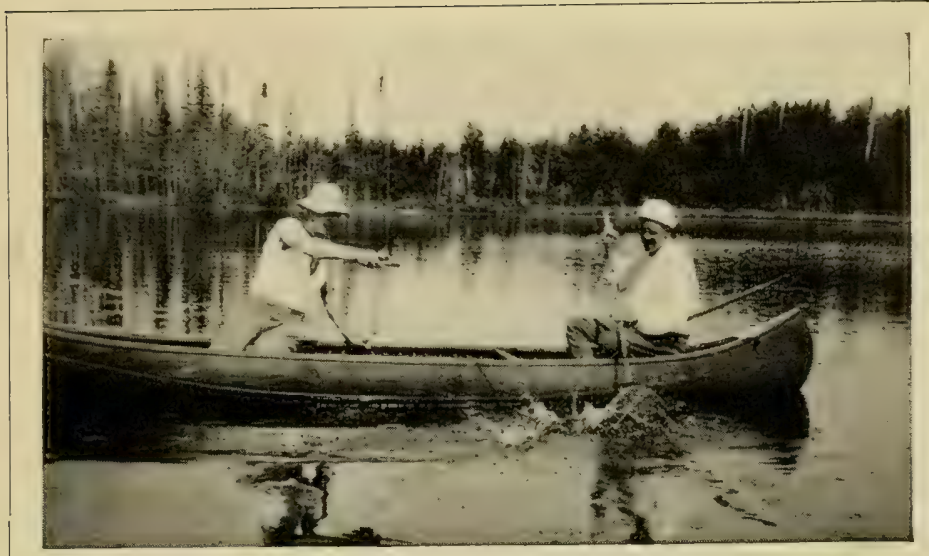

The wrong way to shove the landing net in the fishes face and expect to land him. This scares any sure enough frisky game fish into a final effort at the vital moment, and he generally gets away; but note the correct position of the chap with the rod. He places his weight on the opposite side of the canoe as a balance to his pardner with the net.

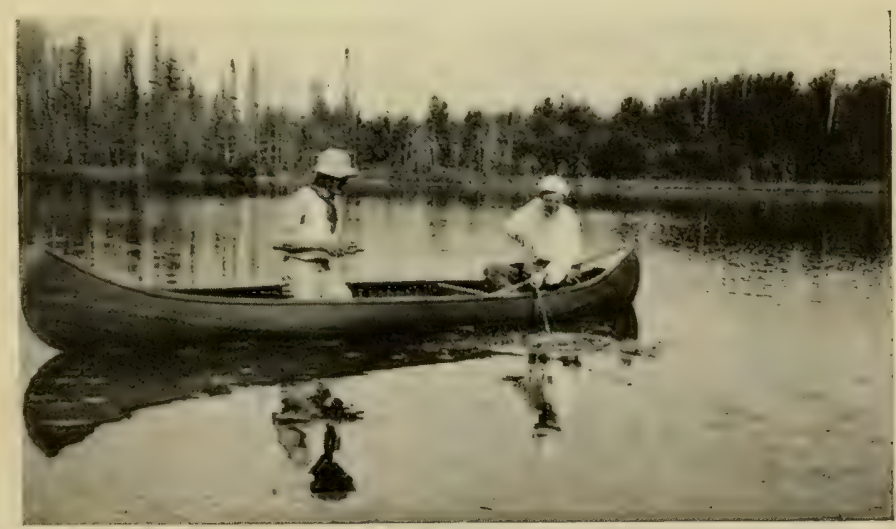

The correct way is to drop the net down in the water and then the rod man leads the fish over it and the game one drops in on the upward raise of the net. 

in a fair wind and it's no easy game to keep ahead of one.

Having relieved myself of this advice, I feel better; everybody does after slipping the advice stuff to some one. But after having raced with one forest fire, trying to beat it to the safety zone and just making it by the skin of the teeth, and a few years later passing seven hours in the chilly lake water, in September, in Minnesota, while the fire raced along the shores, trying to keep one's feet steady on a sand-bar with a gale working " likell" to throw you off and into the deep water; not to mention a fairly well parboiled back, face, and shoulders from the cinders and intense heat, with a duck under the water every time you decided you could not stand the gaff another second, one can fully appreciate the great necessity of following this one rule of the true woodsman BE SURE YOUR CAMP-FIRE IS OUT THEN PUT WATER ON IT.

This seems to be a time when a fellow is simply bubbling over with advice. Now we come to our regular annual request

Throw Back the

Little Fellers,

Make Fishin' Better

increase the percentage in order that our fishing may back the little fellers," so that they may grow up, raise a family or so, and

that all anglers "throw 
be better each year instead of passing back into the kick-off stage, like a lot of past performers in the game end that have been exterminated by the pothunter before the passing of laws to conserve the species.

We all know there are laws governing the length of game-fish that may be legally dropped into the creel or slipped on to the stringer; but sometimes a fellow will take a chance, and, if nobody is looking, stretch the imagination a trifle as well as the length of the fish and keep the little unsophisticated tailkicker. And the little rascal did not put up much of a fight, did his best, of course in a frightened sort of a way, and it was no credit to one's tackle skill to bring him to net. 'Course if he had a couple years more to kick around in the water, learning the tricks of his ancestors, he would put up a rattling good fight - something to go miles to join in.

In returning one of these babies to the water, care should be exercised in disgorging the hook in order not to injure the youngster, and one very important thing to do, is always to wet the hand before holding the fish so that the protecting film over the scales will not become broken or injured. It is this film that keeps germs in the water from eating into the vitals of the fish and eventually killing them.

While enjoying the thrills of the dashing fight of the battling game-fins, think once in awhile of this future supply and about how you will want to fish 
when you are trailing a bunch of whiskers around in the coming years. I'm stacking a bunch of chips that you will put the little fellers back with a smile and good luck to 'em.

Conservative estimates place the number of anglers in this great old country at close to two million.

Make an Outdoorsman of a Friend this Year
Some bunch, fellows, when you come to think of it. What a great army of keen fellows following the principles of good old Izaak Walton, dean of all anglers! We who go out along the water-trails know of and enjoy the pleasures of angling. The call is so strong within us that we answer it even should it happen to be but a murmur. In fact, we are so alert for the least sign of a fishing-trip that we don't even wait to be called.

Why not take a friend along this year, each and every one of us, and make this figure a cool four million? Take a friend along who does not know of the joy of angling - show him the way to a happier life and at the same time, better health. If every one of us would do this missionary work this season, we will have done much for humanity, much toward the making of better citizens and much to the general good of the country. Never will the friend forget that he made his first trip in quest of the game- 
fish with us, and never can he thank us enough for leading him into the walks that are ours. Slip a new pal the glad invitation this year - help make life better.

What about the "Reds"? By this I mean, brothers of the outland trails, the whole layout of

American Sportsmen, Minute Men of I920, Be Prepared! anarchists, communists, bolsheviks, who are trying to undermine law and order in these fair states of ours, trying to run this grand old country on the rocks. Every one of these tangled-brained members of the soviet clan has a hankering to get their hands around the throat of Miss Columbia and squeeze. This is no idle jest, no flight of fancy; the reds are among us and working to spread the idea of radicalism throughout the land. It is a known fact that the country, particularly in the larger cities, swarms with agents of Lenin and Trotsky, the red leaders who have scattered arson, rape and murder throughout Russia, and that funds from the Russian Soviet are being used to finance this wild-eyed dream of the reds to damn this country of ours forever, not to forget that much of this social unrest spotted here and there throughout the land is the growth, like a rank weed, of the poisonous seeds dropped by these advocates of the "coming revolution," as they call it. 
Is this fair land of ours, and of our fathers, to become a flaming torch and be drenched with the free blood of Americans and their families; our women to feel the unclean hands of mob rule; our homes defiled by a raving bunch of maniacs who do not know right from wrong; law and order from violence; the sanctity of our womanhood from the free love they advocate? Not while a drop of blood remains in the veins of five million sportsmen can such a thing take place, I answer, for myself and the great clan of sportsmen, true Americans, followers of the woods and water trails. These Minute Men of I 920 will rise in a unit and crush any attempt to drag in the dirt the glorious old flag we love and supplant it with the red flag of rebellion and anarchy.

I am not a pessimist; it is not my nature to follow the dark and gloomy side; I love the sunshine of the optimist, the rustle of the running stream, the laughing ripple of the wind-kissed lake waters, the smiling, happy face of the outland pal - but, when there is a rumble in the clouds, the sun goes into hiding, and things point to bad weather, then getting everything shipshape and being prepared is mighty good policy even if nothing develops and the sun comes out to liven things up again.

Naturally these raven-hued human buzzards may not be able to find enough weak-minded followers to raise their courage to come out in the open to pull this "coming revolution" they squawk about, 
but should they by accident dope up enough false courage to come out from behind their bomb system and start something, let all of us sportsmen who love our country and its open stretches, step forward ready for action and slip 'em the sting of a $\cdot 30-30$ or a full charge of buckshot as a little reminder that they are stepping wrong in this free land of ours.

To be ready for such emergency is not merely to sit back by the fire and cuss them out as a bunch of varmints and saying that you are ready any time you are called for - but let the sportsmen of the whole country, five million strong, be able to say to the sheriff of their respective counties, "I am ready for instant service when you want me, and ready with one hundred rounds of ammunition." What does this mean to a community? Simply that there are on hand a band of loyal true Americans that the sheriff can call instantly to come forward in the name of law and order, ready to protect the homes and womenfolk against any outbreak that might develop from the poisonous, insidious vaporing of weak, rattle-brained radicals. It places in the hands of the sheriff of every county in the United States a force of loyal Americans who can shoot and shoot to kill, men who are armed and ready with ammunition. For an emergency force they would be able to restore order quickly and with rattling good results, without it being necessary to round up ammunition and guns from the state arsenals. If anything 
should ever break in the rough-house line by the "reds," speed on the part of law and order would nip the game in the bud, and I can think of no better way to quickly get together an armed force of men than for the sheriff to have a list of sportsmen to whom he can issue the call instantly and know that they would quickly rally to his colors with the necessary tools of the shooting trade and the stuff that goes with them. Anarchy relies on a sudden outbreak of terrorism to subject the greater majority of the people to their smaller numbers, using the gun, the knife, the bomb, the torch or any other devilish method they can think of, and a few quick loads of buckshot or bullets would make them cringe in their holes and yip for peace. My own personal opinion is that more use should be made of stone walls and a firing squad for those who try to wreck a country. If this little old country is not good enough for any one who has come to our shores, the best thing for such people is to "get out and get out damn quick"; if they come here with the sole idea of tearing down our laws and institutions, then the firing squad is just a trifle too good for them.

As a little old "safety first" in the red game, let every American sportsman secure one hundred rounds of ammunition for his favorite gun and fifty rounds for his hip gun and then immediately notify his sheriff that he is so prepared and ready for instant orders should the sheriff need him in case of trouble 
with the reds. No uniforms would be necessary to make a gang like this effective, but what better service, what more honorable service, could be given by your old hunting coat, than to wear it in the service of your country, your homes and your women folks.

Let this be a summons to the sportsmen of the country to answer the call of the Minute Men of I920. Be prepared; get your ammunition and notify your sheriff. Trouble may not come, but if it does, let the sportsmen of this fair land be the men who through love of flag and home crush under their heel the venomous snake of anarchy and terrorism, if it tries to debauch the fairest, freest country on earth. American sportsmen - act now-Be ready!

Twelve years of comradeship are ending to-night, twelve years of merry hikes afield after the jumping

Hunting Out the Long Trail little Molly Cottontail, my old beagle is about on her last pegs. No more will she follow the trails of the nimble little Br'er Rabbit singing the lively yip of the hot scent. Twelve years we have been kids together, kids of the field and camp. Badly scarred from many battles, carrying a few shot around for years, yet glad to hit the trail even now if her poor ol' legs would carry her. Talk of the hunt and the tail gives a knowing wag, the ears 
cock up and the eyes carry an answering gleam. The will is there but the weakened, worn and tired little frame has not the strength to move.

Up all night with Trix, glad to do so, glad to be able to try and help this pal of so many wonderful trips afield, to ease her along the long trail, glad to rub her aching muscles, 'cause she knows her pal is doing all he can to help her, glad to wash her mouth and tongue with cooling water to take the fever down a little. 'Course she cannot speak to me, but I know, and any fellow who has ever had a dog pal knows, that she understands and every wag of that stumpy little tail is her way of showing her affection and that she knows.

While I sit here doing what I can, there's a flood o' memories come back to me of the many jaunts afield we've had together and just at the break o' day she slips over the big portage with her head along my knee. Kismet.

Out-o'-luck, buddie, flat on the back with old Mistah Flu and his dark, dizzy cohorts all hiding

Out-o'-Doors on Dreamland Trips around waiting for a chance to swat you between the eyes and knock you for a goal. You don't know much about the beginning of the scrap, the wife tells you that you talked "bugs" the first day or so and now that you are getting a bit better a little pep 
crawls in and you try to order things so and so, but the old Medico still has complete control, so we just lay back and do a little aimless thinking until the "big chief" o" the sick room rubs our head with a few soft strokes that sends our canoe out along another bass stream of the land o' dreams.

About the third day, we think we are a big bass, down in a deep cool pool and along comes a nice silver shiner right into our mouth, we snap the jaws shut and then dimly hear the Doc say, "temperature around I04 degrees when he bit the thermometer in two ; hand me the other one from my case, please," which is the first we know that they have us spread out on our back. And when we raise an arm just to see if it is still there the darned thing don't even raise at all, and from that point on, buddie, it's a great trip of discovery. We never knew so many aches could be concentrated in such little spots. If we ever meet the gang who were camping in the back of the roof of our head trying to kick the lid off, we sure will hand 'em a wallop for luck.

Ghee! how a fellow wants to get out-o'-doors when it just cannot be done and we never really knew how many, many years there are in each hour when one is flatter'n a pancake the sixth day in the same ol' bed. Pancake fine, that gives our memory another trip back a couple years at the camp on Pine Island before the war when the three of us baked pancakes in contest. Some cakes, golden 
brown and of the size of the spider and great was the sport of judging for the blue ribbon and many the arguments as to mixture and when to toss 'em in the air for the best results. And of the lads around the camp-fire that night, two never came back from France.

We know the number of flowers on the wall, because we have counted them time after time, and the wonder to us is, why the pink ones never crawl completely over the blue ones, and great guns, we discovered a lot of butterflies flitting through the flowers, which took us back to the August on the upper Mississippi when the yellow butterflies were on wing, and the every cast of our Yellow Sally was met with a walloping crack by an over-enthusiastic small-mouth bass. They struck with a snap like a pistol shot and the floating Yellow Sallies never had more than a chance to kiss the water before the bass took 'em. And just a couple weeks ago Jack Dahlgren, great lover of the out-doors and a keen fly fisherman of La Crosse, Wis., one of the lads on that trip, made the last long trail of the outdoorsman.

Three days the snow flakes have gone drifting past the window and the sunlight scintillating through them made them look like fairy flowers, just the kind of snow to pile up around the cabin and make a hike on snow-shoes the real stuff, threw me back a peg or two in memory to the time Mac left the snow-shoes too close to the evening camp-fire way 
back in the Blue Stone country and the next day we had one helova time making the eight miles through the deep snow in slashings and burnt-over back to the head camp and how the blizzard made the last two miles or so look like we never would make it. You can bet every old familiar Norway pine on the tail end of that hike looked as good to us as a familiar lighthouse to a Gloucester skipper along the Maine coast during a heavy blow.

So long, fellows, I hear the Medico in the offing, he will now come in, look for a fever, count my teeth, pound me on the chest, take a squint at my eye, make a few passes and demand more quiet. Why couldn't he drop in, bring a poker deck along and sit in a few hands of penny ante to pass some of these eons of time away while no one was looking, but then we would not take so many memory trips each day and raise a fever for him to find every time he shoves that little silver bait in our mouth.

Our National Parks. Yep, sounds sort of big; reminds us of the government and reading the Con-

Our National Parks Are the People's Playgrounds stitution of the U. S. at the old-time Fourth of July celebration and we don't go into details, just let the matter slip along at that, and we outdoorsmen, the people who are really vitally 
interested in these wonderlands of Nature and their development, are missing the greatest handiwork of the Great Architect Who created them for His children.

The national parks throughout the country have been selected because these different locations are supreme examples of their kind, scenery of distinctive quality, or some natural feature so extraordinary or unique as to be of national interest and importance that should be developed for the benefit of the people.

Being of the people and for the people, which means, fellows, you and me and the lad in the next boat, that we are overlooking a winning bet by not packing the duffe and hitting the trail for one of these beauty spots of nature. That is, some of us are playing the losing hand because figures speak right out in meeting and they speak with a fairly loud yelp. During 1919 season over 750,000 people visited the national parks. Over 750,000 lovers of nature and the out-o'-doors enjoyed the wonders of their own parks. A mighty big figure - a heap o' people out of the entire population of our grand country and it's a sure-fire bet that these people, every last one of them, are little missionaries spreading the gospel of the Parks to their friends. These national parks, long considered by many as a financial liability to the government, are in reality one of our biggest economic assets. Outdoor Americans, 
who do their own thinking, have long known that vacations in the natural parks, where nature is at her wildest and best, are the surest antidote for the many ills of our speedy twentieth century civilization.

The national park movement is nation-wide, and it is interesting to know that while in I9I 5 most of the park visitors made the parks via the railroads, in I9I9 an analysis shows that the bulk of the travel was by automobile from all parts of the country, which makes it look as if "Seeing America First " and really knowing one's country was at least coming into its own. Laying aside the big wonders to be found in the parks proper, is there any finer way to see just what a great big, fine land we live in than to tour across its wide stretches, between blowouts and punctures?

And what does it mean to the country, besides educating the people? Formerly a great part of this touring outfit hit the water for Europe and dropped a golden stream of American money in a wide swath across the old continent, leaving a nice sized stack of something like $\$ 225,000,000$ annually in little Switzerland alone and to see a bunch of mountains, etc., that have nothing on those of Glacier, Crater Lake, Yellowstone, Mount Rainier or Rocky Mountain Parks. Now we can tour our own country, see what she looks like at her grandest 
and what " jack" it costs stays right here and helps keep things humming in our own land.

Moreover, as tourists we buy outing clothing, fishing tackle, field glasses, cameras, lunch kits, camping outfits and a thousand and one things useful and ornamental. We buy long before the start and all along the way. Everybody along the route - from the outfitter in the home town to the grizzled guide in the mountains, gets a cut of our coin and the merry law of averages works it back to use while circulating in our own country.

The national parks are symbolic of the democracy of the people. We out-o'-doorsmen can make the parks à la nature, we don't have to wear a "boiled" shirt during the trip, nor make the hotels unless we are so inclined, we can slip into our regular outing togs, take the old camping outfit along and make an honest to goodness close to nature ramble out of the park trip, and as far as fishing goes, we find the finest kind of trout fishing throughout the mountain parks. We can follow the trails that give us the wildest kind of going and we find nature just as she has been for countless ages, and will be for those that follow us.

The national parks movement is in no way political, and it should have the undivided support of every American who loves his country, its natural wonders and the great outdoors. The parks are 
free and open to all of us; we all have a heritage in them and we want our children to have these natural beauty spots preserved for them. When other parts of the country that are now wild and untouched by the inroads of civilization answer to the demands of commercialism and the factory takes the place of the birch and elder of the streamside, then these national parks will really come into their own and get the appreciation from the public which is due them. Through these parks, we of this generation can create and instill in the hearts of the younger ones a love of the outdoors that will make for better citizens and better citizens means keeping this country up to the high standards of our forefathers.

$\mathrm{Up}$ until the creating of LaFayette Park in I9I9 on the Isle of Mount Desert, off the coast of Maine, all of the national parks were west of the Mississippi River. During the past season, the first in which this new park was open to the public, 64,000 visitors made the park, which shows that the east appreciates nature and wants more of it.

The east needs more parks for the great mass of population of that section, and there are plenty of natural beauty spots that would make national parks of the finest and still be right handy to the big crowd. Although the mountain country of the east is not as rugged as the western ranges, yet the ridges and valleys of the east are beautifully wooded, and one can travel many a moon before finding as rare a 
sight as the Adirondacks, the Alleghenies or the Blue Ridge mountain country. And this goes double for the October days, when nature has minted the leaves to the many tints of gold and orange, daubed here and there with the blood red sumac and maple against a glorious background of greens of the pine, hemlock and spruce, slashed here and there with the silvery threads of the mountain streams that tumble and roam along on their way to the sea.

For the many outdoorsmen, the sportsman and particularly the angler there would be nothing finer than a fair sized national park in the Adirondack country, where the streams could be protected and stocked systematically by the government so that fishing could be enjoyed by thousands of fellows and their families who probably could not make the big hike 'cross country to the western parks where trout fishing is one of the big attractions to the outer. Camps throughout the park, with hiking trails through the mountains, canoe routes with camping places along the way, all under government control would make a park that would draw hundreds of thousands of people to the out-o'-doors who have never heard the call before.

Another park for the outer, that would make the attendance records of the present parks look like an "also-ran" could be laid out in the lake country of the north woods of Wisconsin. This great natural wonderland along the divide between the Missis- 
sippi valley waters and those that flow into the Great Lakes and the St. Lawrence, famous the world over for its bass, trout and musky fishing would be the Mecca of many thousands of followers of the woodland and water trails.

Yes, buddie, I am for the national parks, those that we now have with us and more that we should have and every sportsman should get behind this movement which means so much to the outdoors clan and those who follow in our footsteps. To the "little army" of good Americans, "the army of national park enthusiasts" as they have been called, clean cut citizens who have given much of their time and enthusiasm to the furthering of the national park idea, we all owe a vote of thanks for their untiring efforts to keep up the interest and work in the parks.

If we can do it this year, fellows, let's see one of our national parks, places of beauty and grandeur in which we all own an interest. 


\section{WHERE TO GO A-FISHING}

During the past few years I have had many requests for information on where to get the musky, the old roughneck of the weed-beds, the smallmouth bass, the trouts, the wall-eye pike and the pike. Thinking that a condensed list of some of the most popular places in the different fishing waters would be of interest to most readers, and of help to them in planning their pilgrimages to the outlands, I have selected here a few of the good fishing points in Wisconsin, Minnesota, the north Pacific coast country and Canada. During the past three years, I have either fished at these points or have had reliable reports from anglers, members of the American Anglers' League, who have fished the waters upon which they reported, and I feel that a cast in any of these waters will bring joy to the angler's heart and fish to his stringer or creel. 


\section{WISCONSIN FISHING WATERS}

The North Woods of Wisconsin are spotted with so many lakes and threaded with so many streams that it seems you could step from lake to lake, and in fact, one could spend a lifetime in a canoe making this wonderful fishing country passing through these waters without more than the ordinary portages to be found along any chain o' lakes. And each lake is a new field for finny battles with the roughneck fighter, the musky, the fast scrapping small-mouthbass and the bull-dog fighter, his cousin the largemouth bass, or the stream raised rainbow trout with his electrofying speed. Not to forget the graceful fight of the brook trout or the tugging battle of a large wall-eyed pike.

Many of these lakes and streams of northern Wisconsin are so grouped and connected that they have been classified under names and such waters have a reputation for the splendid fishing which they supply. The Three Lakes Waters, jumping off place Three Lakes, Wis., are a group of lakes good for musky, bass and pike and are connected with the Eagle Waters. From Three lakes you reach the famous Butternut lake, twenty miles in the timber, 
where some of the finest small-mouth bass fishing in the country is found. A bit north of Three Lakes are the Eagle Waters, jumping off point Eagle River, Wis., fine for musky, bass, great northern pike and trout. Here is the starting point of the famous Wisconsin River canoe trip with the windup at Rhinelander. A bit north of the Eagle Waters at Phelps, Wis., we have Long Lake with a reputation for big small-mouth bass and musky and just north a few miles farther and we leave the steel at Donaldson, Wis., for Lac Vieux Desert, noted for the large size of the musky taken from its waters, and heading in west we hit the Cisco Chain on the divide where the waters running north give us excellent trout fishing and those running south fine for small-mouth bass fishing.

A little west and on a line with the Three Lakes Waters we have the Tomahawk Lake Waters with the jump off at either Tomahawk Lake, Wis., or at the upper end at Woodruff, Wis., and from this latter place we also hit the Arbor Vitae and St. Germain Waters on the east, all good musky and bass fishing. A little farther north brings us to Lac Du Flambeau Waters of the Lac Du Flambeau Indian reservation, jumping off place Lac Du Flambeau, which also serves for the Trout Lake Waters off to the northeast.

A few miles north we strike Powell, Wis., the heading in place for the Manitowish Waters with 
the lakes and streams of the big musky and bass; here is also the kickoff for canoeing the Manitowish and Flambeau Rivers, fine for the stream raised musky. Just north of Powell brings us to Mercer, Wis., going in place for the Turtle Waters and a trifle northeast is Winegar, Wis., which drops us into the Presque Isle country, the real primitive back to nature part of Wisconsin with its lakes lined with virgin timber and full o' fish worth fighting.

Long Lakes, Phelps, Vilas Co., Wis. Excellent small-mouth bass fishing, run to good size, musky, wall-eye pike and stream trout fishing, first class resort accommodations and camping outfitting, guides, boats, etc. For information, Chas. E. Hazen, Phelps, Wis.

Twin Lakes, Phelps, Wis., Vilas Co. Good large and small-mouth bass fishing, musky, pike and wall-eye pike, wall-eyes run big, resort accommodations good, boats, guides, etc. For information, Andrew Hansen, Phelps, Wis.

SPider LaKe, Manitowish, Vilas Co., Wis. Excellent bass, musky and pike fishing, centers in fourteen good lakes of Manitowish waters, many big musky from here. Good canoeing waters, accommodations first-class. For information, T. J. Koerner, Manitowish, Wis.

Big St. Germain Lake, Woodruff, Oneida Co., Wis. Excellent small-mouth, red-eye bass, 
musky, pickerel, great northern pike and walleye fishing. Very fine accommodations and equipment. For information, Amedee Chabrison, Musky Inn, Woodruff, Wis.

Lake Mamie, Donaldson, Vilas Co., Wis. (R. R. station, State Line, Mich.) southeast end of Cisco Waters, 75 lakes can be fished by canoe from here, good bass, musky, pike and pickerel, small-mouth bass A-I. Good accommodations. Information, Charley Bent, Donaldson, Wis.

Tenderfoot Lake, Vilas Co., Wis. (R. R. station, Cisco Lake, Mich.) northwest end of Cisco Waters, very good small-mouth bass fishing, pike, pickerel and musky and trout fishing, fish many lakes from here, good accommodations, in heavy timber country. Information, C. E. Lundberg, Watersmeet, Mich.

Lake Alma, Vilas Co., Eagle River, Wis. Good bass, pike, wall-eye pike, trout, lake and stream musky. Fish Lakes Alma, Moon, Findley, Little St. Germain. Accommodations great, equipment good. For information, George H. Jackson, Eagle River, Wis.

Little St. Germain Lake, Vilas Co., Eagle River, Wis. Musky, pike, bass, wall-eye pike and stream pickerel, from here fish 20 mile stretch of Wisconsin River, fishing good. Good accommodations and equipment. For information, John R. Powell, Eagle River, Wis. 
Black Oak Lake, Donaldson, Vilas Co., Wis. ( $R$. R. station, State Line, Mich.) Good salmon trout, bass, pike and trout fishing. A dozen connected lakes fished from here. Very good accommodations. For information, Geo. J. St. Clair, Donaldson, Wis.

Lac Vieux Desert, Donaldson, Vilas Co., Wis. (R. R. station, State Line, Mich.) Largest inland lake in Wis. Great for musky fishing, running to exceptional size, small-mouth bass, trout and wall-eye pike, trout streams nearby. Accommodations, boats, guides, etc., of the best. For information, John Lobischer, Donaldson, Wis., and Louie L. Thomas, Vudesare, Wis.

Meta Lake, Eagle River, Wis. Centers on a chain of 27 lakes in the Eagle River Waters; very good bass, musky, pike and trout fishing, equipment, boats and accommodations very good. For information, Horace Tilden, Eagle River, Wis.

Ballard Lake, Eagle River, Wis. Good bass, musky, pike and trout fishing; 25 lakes can be fished from here and five trout streams. Very good accommodations and equipment. For information, Ole Rismon, Star Lake, Wis.

SpIRIT LAKe, Oneida Co., Three Lakes, Wis. Pike, musky, bass, wall-eye pike fishing good; can fish Three Lakes Waters from here. Fine canoe trips, through chain o' lakes; accommodations 
and equipment good. For information, W. A. Beach, Three Lakes, Wis.

Butternut Lake, Forest Co., Three Lakes, Wis. The best small-mouth bass fishing in many a day; trout in nearby streams. Twenty miles in the timber; A-I accommodations in every way for real fishermen and their families. For information, Gus. Griswald, Three Lakes, Wis.

Star Lake, Vilas Co., Eagle River, Wis. Musky, and great northern pike fishing good. Fish Plum, Razorback and Rice Lakes from here also. Accommodations and boat equipment very good. For information, John W. Oliver, Star Lake, Wis.

Manitowish Lake, Manitowish, Wis. Very good musky, pike and bass fishing; fish from here twelve lakes well bunched and connected all good fishing; equipment and accommodations very good. For information, Chas. H. Doriot, Manitowish, Wis.

Little Arbor Vitae Lake, Vilas Co., Woodruff, Wis. Very good bass fishing in Arbor Vitae lakes and good musky fishing in Carroll and Madeline lakes, fished from here also pike and pickerel. Accommodations and equipment O. K. For information, Otto Mielke, Woodruff, Wis. Tomahawk Lake, Tomahawk Lake, Wis. Good fishing for musky and bass in Tomahawk and lakes connecting. Very good accommodations 
and all kinds of equipment. For information, Chas. Sanders, Tomahawk Lake, Wis.

Seuirrel LAKe, Oneida Co., Woodruff, Wis.

Very good bass, pike and musky fishing. Accommodations and equipment first class. Information from Henry Hansom, Woodruff, Wis. Pike Lake, Price Co., Lac Du Flambeau, Wis. Good musky, bass and pike fishing; also fish Round, Squaw and Rice lakes and Flambeau River from here; accommodations and outing equipment O. K. For information, Ross \& Simpson, Lac Du Flambeau, Wis.

Lac Du Flambeau, Lac Du Flambeau, Wis. Very good bass, musky, pike and wall-eye pike fishing here. Fish Crawling Stone, Fence, Long, Pokegama lakes from here, also Bear River; accommodations and equipment good. For information, B. Gauthier, Lac Du Flambeau, Wis.

Fisher Lake, Iron Co., Mercer, Wis. Fine musky, bass, pike and wall-eye pike fishing, west end of Turtle waters; also fish Cedar, Pardee and No Man's Lake from here; some big wall-eyes from these waters. Accommodations and equipment O. K. and for information, Herman E. Mielke, Mercer, Wis.

North and South Turtle Lakes, Vilas Co., Winchester, Wis. Very good bass, musky, pike and trout fishing. Centers Turtle Waters; connected lakes and streams good fishing. Accom- 
modations good, also equipment. For information, Buck \& Son, Winchester, Wis.

Presque Isle Lake, Vilas Co., Winegar, Wis. In the timber country and very good fishing; smallmouth bass, musky, great northern pike and walleye pike and trout; also fish Papoose, Ox Bow, Crab, Wolf, Crooked and Boulder lakes from here. Many canoe trips through connected lakes; accommodations good. For information, Geo. Nelson, Winegar, Wis.

For all around information on the northern Wisconsin waters, the writer will be pleased at any time to give such information and data he has gathered from many years' fishing there and from reports sent in from time to time by guides, trappers and fishermen. 


\section{MINNESOTA FISHING WATERS}

To try and name all the good fishing points in Minnesota would be to practically take the whole state, in fact there are over ten thousand lakes that are real fishing waters and all the game fish have natural breeding waters in this state. While the musky, large and small-mouth bass, great northern pike and cold water pickerel predominate there is very good trout, lake trout, sturgeon and white fish as well as pan-fishing that runs to good size.

You can get fishing from the handy summer resort lake to the rougher, way back in the hinterland camping layout and for the real back to nature stuff the far northern end of the state, north and northwest of Duluth is real going. Here is a selection of some thirty locations, covering both the closer-in places and the far north wilderness lakes.

Lake Geneva, Alexandria, Minnesota, has good bass and wall-eye pike fishing, many other lakes connected by channels, streams nearby; excellent resort accommodations. For information, Geo. L. Treat, Alexandria, Minnesota. 
Clearwater Lake, Annandale, Minnesota, seventeen lakes in this vicinity, largest being Clearwater. Splendid bass and pike fishing; good resorts at all lakes. For information, Geo. C. Schierts, Annandale, Minnesota.

White Bear Lake, St. Paul, Minnesota, bass, pike and pickerel fishing; reached by electric line or automobile from Twin Cities. Excellent accommodations. For information, St. Paul Association, St. Paul, Minn.

LAKE BEMidji, Minnesota, surrounded by dozens of other lakes; pike, pickerel, bass and trout are found in the smaller lakes, while large whitefish and muskellunge are caught in the larger lakes, excellent in-the-city hotels and summer hotels at lakes. For information, H. M. Stanton, Bemidji, Minn.

Gull Lake, Brainerd, Minnesota, one of the chain of fifteen lakes from one-quarter mile to twelve miles in length. High class resorts, fine pike, black bass, pickerel, crappie and perch fishing; for information write Chamber of Commerce, Brainerd, Minnesota.

Cass Lake, Cass Lake, Minnesota, excellent muskellunge, pike, bass, pickerel, and whitefish fishing; many other lakes nearby, good accommodations. For information, write M. N. Koll, Cass Lake, Minnesota.

Chisago Lakes, Chisago City, Minnesota, chain 
of fine lakes, good bass, pike, pickerel and crappie fishing, good resorts. For information, David Bloom, Center City, Minnesota.

Trout Lake, Coleraine, Minnesota, good bass, muskellunge, and trout fishing in the many lakes and streams which are easily accessible, good accommodations. For information, write Jos. H. Galipeau, Coleraine, Minn.

Deer Lake, Deer River, Minnesota, excellent bass, muskellunge and pike fishing, good camping sites and summer resorts, bait or fly fishing. For information, S. J. Moran, Deer River, Minnesota. Pelican Lake, Detroit, Minnesota, pike, pickerel, crappies and black bass in abundance, excellent resorts and in-the-city hotels, many other lakes nearby. For information, Fred Dennis, Detroit, Minn.

Mantrap Lake, Dorset, Minnesota, noted "muskie" fishing lake, also bass, pike, pickerel and crappies; boats, tackle and guides available, good resorts.

White Iron Lake, Ely, Minnesota, lake trout and brook trout, wall-eye pike, black bass, whitefish, muskellunge and pickerel fishing, good summer resorts, baits or fly fishing. For information, George L. Brozich, Ely, Minn.

LAKE Vermillion, Tower, Minnesota, nearly 700 miles of shoreline, wall-eye pike and muskellunge and land-locked salmon fishing, numerous sum- 
mer resorts. For information, H. T. Olson, Tower, Minn.

Interlaken Lakes, Fairmont, Minnesota, good pike, bass and crappie fishing, good resorts. For information, T. E. Himmelman, Fairmont, Minn.

Lake Minnewaska, Glenwood, Minnesota, good black bass, pike, pickerel and crappie fishing, first class summer resorts. For information, C. J. Wollan, Glenwood, Minn.

Pokegama Lake, Grand Rapids, Minnesota, whitefish, muskellunge, bass and lake trout fishing, many smaller bass and pike fishing lakes nearby, good accommodations. For information, C. W. Huntley, Grand Rapids, Minn.

Woman LAKe, Hackensack, Minnesota, good muskellunge, bass, pike and pickerel fishing, fine resorts. For information, E. M. Bartholmey, Hackensack, Minn.

RaIny LAKe, International Falls, Minnesota, pike, pickerel, lake trout, sturgeon, black bass and muskellunge are plentiful. Rainy Lake district has within its boundaries several thousand smaller lakes, many of them still unfished, good camping sites and in-the-city hotels. For information, David Hurlburt, International Falls, Minnesota. Lake Minnetonka, Minneapolis, Minnesota, good bass, pike and pickerel fishing, excellent accommodations. For information, Civic \& Commerce Association, Minneapolis, Minn. 
Shamineau Lake, Little Falls, Minnesota, good bass, pike, muskellunge and crappie fishing, good camping sites. For information, W. E. Olson, Little Falls, Minnesota.

Lake Mille Lacs, Aitkin, Minnesota, largest lake in the state, good large and small mouth bass, pike, pickerel and crappie fishing, good accommodations. For information, R. W. Rogers, Aitkin, Minnesota, or Geo. L. Ticknor, Onamia, Minnesota.

Big Stone Lake, Ortonville, Minnesota, good bass, pike and pickerel fishing, fine resorts. For information, Geo. M. Fosburgh, Ortonville, Minnesota.

Lake Osakis, Osakis, Minnesota, bass and walleye pike plentiful, fine summer resorts, launches, row-boats, and guides available. For information, E. R. Ruggles, Osakis, Minnesota.

Mantrap, Crow Wing and Fish Hook Chains, Park Rapids, Minnesota, numbering 37 lakes, excellent muskellunge, bass, pike, pickerel and crappie fishing, excellent summer resorts at all lakes. For information, Ben Glantz, Park Rapids, Minnesota.

LAKE of THE Woods, Warroad, Minnesota, good pike, pickerel, whitefish, lake trout, sturgeon, black bass and muskellunge fishing; good camping sites. For information, Paul Marschalk, Warroad, Minn. 


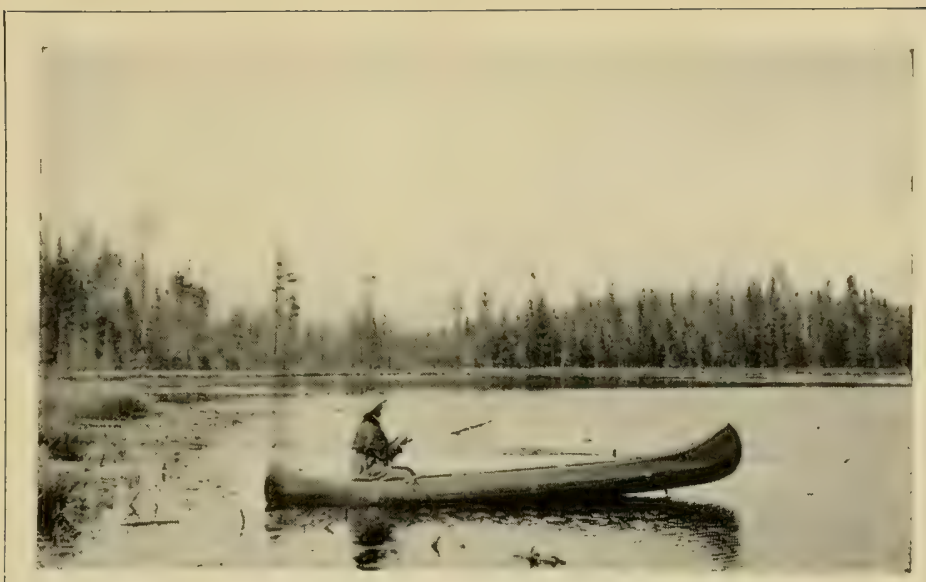

In playing the casting game alone, I have found that after casting a piece of water one can cover more water by letting the canoe run in to shore and then cast both sides lengthways and in front. You can attract many fish by casting downshore and reel in over good water all the way back to the next cast.

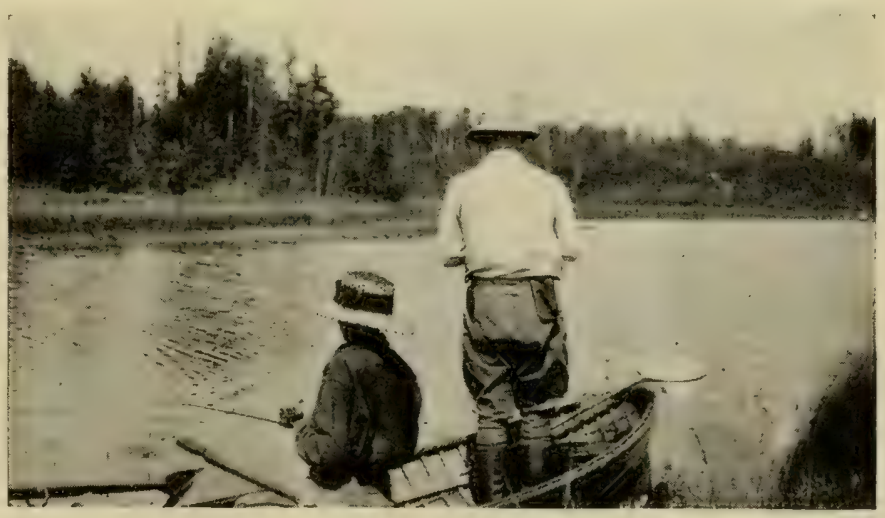

The narrows between two parts of a lake is a regular thoroughfare for game fish particularly wall-eye pike, pike and musky. Run the boat ashore and cast across, up and down. If you don't get a strike, you re "out-o"luck," because the fish sure use that water boulevard. 

Madison Lake, Mankato, Minnesota, good bass, pike, pickerel and crappie fishing, good resorts. For information, Commercial Club, Mankato, Minn.

Lake Jefferson, Cleveland, Minnesota, good bass, pike, pickerel and crappie fishing, good resorts. For information, Joe Hardaegger, Cleveland, Minn.

LeECH LAKE, Walker, Minnesota, excellent muskellunge, bass, pike and whitefish fishing, good resorts. For information, Gus Kulander, Walker, Minnesota.

Lake Sylvia, South Haven, Minnesota, good large and small-mouth black bass, pike and pickerel fishing, good resorts. For information, Commercial Club, South Haven, Minnesota. 


\section{PACIFIC NORTHWEST FISHING WATERS}

For the trout fisherman the waters of the streams and lakes of the mountainous Pacific northwest make ideal wet and dry fly casting. These waters are cold and fast being broken by rough water that gives the trout family just the layout that makes them the premier fighters they are. And the variety of the trout seems endless, from the Deschutes River in Oregon come the famous redside trout, this stream being fine dry fly fishing while the Willamette River, right above Portland, offers rattling good Chinook salmon and the Siuslaw River down in Lake County, Oregon, flowing from the Coast Range Mountains directly into the Pacific Ocean, is fine for sea trout. In Lake Crescent, Washington, we find the famed, but scarce, Beardsley trout, the Crescenti and cutthroat while at Lake Chelan, at Chelan, Washington, has excellent lake and cut-throat fishing. There is good salmon fishing at the mouth of the Campbell River at the northeastern end of Vancouver Island, while the river proper is great for trout and the trout fishing in the Kootenay River, all along to the pools below Bonnington Falls is greát. 
Deschutes River, Crook County, Oregon. A very large mountain river, with thousands of redside trout. Offers splendid dry fly fishing during May and June. Size 8 and ro dry flies are generally used. For particulars write, B. A. Kendall, Redmond, Ore.

Metolius River, Crook County, Oregon. Tributary of the Deschutes. Water unusually clear and cold. Splendid dry fly fishing for large rainbow trout from April to July. For accommodations and further details write, Dan Heising, Sisters, Ore.

McKenzie River, Lane County, Oregon. Another large mountain river, famous for its rainbow trout. Offers the finest dry fly fishing in the State and is good from May ist to July I $5^{\text {th, }}$ and from September I 5 th to October Ioth. For details write, H. D. Sloan, Belknap Spring, Ore.

Williamette River, just above Portland, Ore. Very fine salmon trolling for Chinook salmon during April and May. Thousands of salmon are caught each year within Io miles of Portland. Write to Backus \& Morris, Portland, Ore.

Rogue River, Jackson and Josephine Counties, Oregon. The home of the famous steelhead trout, which are taken on size 4 and 6 flies, and which range in weight from 2 to ro pounds. Some of the best fishing can be had near Grant's Pass dur- 
ing August and September. Write to Joe Wharton, Grant's Pass, Ore., for details.

ElK LAKE, about 40 miles west of Bend, in Crook County, Oregon. This lake was stocked with Eastern Brook trout 6 years ago, and now contains thousands of this variety, up to four pounds in weight. They are taken with both dry and wet flies, by fishing from a boat. July and August are the best months. For further particulars, write up to Douthit Electric Co., Bend, Ore.

North UmpQua River, Douglas County, Oregon. This river has a run of very large Chinook salmon during April and May, and many are taken on the trolling spoon at the town of Winchester. Fishing is done from small row boats with ordinary bass casting tackle. Write to S. B. Crouch, Roseburg, Ore.

Siuslaw River, Lake County, Oregon. This stream flows directly into the ocean from the Coast Range Mountains, and has a good run of sea trout during April and May. These fish rise very readily to a number 6 sunken fly, and are taken in large numbers during the spring months. Write to Jack Young, Swiss Home, Ore., for particulars.

Nehalem River, Oregon. Another coastal river, which has a good run of sea trout during July and August. A number 4 sunken Royal Coachman fly is the best killer on this stream, and many fish 
of 3 pound weight are taken. For details write, E. H. Lindsey, Mohler, Ore.

Trask River, Tillamook County, Oregon. This is the best of the Tillamook County's trout rivers. It is well stocked with cutthroat trout, which take the fly readily during June, July and August. Write J. S. Lamar, Tillamook, Ore.

Lake Chelan, Chelan, Wash. Good lake and cutthroat trout fishing; lake open season year around. Use troll, bait and fly. Bountifully supplied with small creeks and rivers which all contain trout. Good resorts both ends of lake which is 48 miles long. For information, R. B. Nason, Tacoma, Washington.

Lake Sammamish, Seattle, Wash. Good lake and cutthroat trout fishing. Bass and perch also. Principally trolling with bait fishing. Good fishing lodges. Can be reached within one hour and a half from Seattle. For information, Earl A. Fry, Seattle, Washington.

Bocachiel River, Forks, Wash. Good cutthroat trout fishing. Known as a good fly stream, taking them about July Ist. Good fishing lodge. For information, E. Krogh, Forks, Wash. Quinault River and Lake, Olson, Wash. Good cutthroat, Eastern Brook and steelhead fishing. Upper river best fishing. Trolling and fly fishing. Good fishing and hunting lodge. For information, Herbert Olson, Olson, Washington. 
Skyкомish River, Index, Wash. Good rainbow and cutthroat trout fishing. Trolling, bait and fly fishing in seasons. Good hotel accommodations. Traversed by Great Northern Ry. For information, W. F. Ulrich, Index, Wash.

Silver Lake, Castle Rock, Wash. Good largemouth black bass fishing. Bait and artificial minnow fishing. Good accommodations. For information, R. B. Nason, Tacoma, Washington.

Railroad Creek, Lucerne, Wash. Good cutthroat, Eastern Brook trout fishing. Fly fishing principally. Fishing lodge at Lucerne. Information, Oscar Getty, Lucerne, Washington.

Skagit River, Rockport, Wash. Good cutthroat trout fishing. Upper waters of a stream only. Bait and fly fishing, with flies best in season. Accommodations at Rockport and Marblemount. For information, Earl A. Fry, Seattle, Washington.

Lake Crescent, Lake Crescent, Wash. Good Beardsley, Crescenti and cutthroat trout fishing. Beardsley trout taken on special troll. Others on bait and fly. Good fishing tributary streams. Excellent resort accommodations. For information, Earl A. Fry, Seattle, Wash.

Spokane River, Spokane, Wash. Good cutthroat trout fishing. Bait and fly fishing. Also trolling for large ones. Good accommodations at Spo- 
kane. For information, Garrett B. Hunt, City Hall, Spokane, Washington.

Cowichan River, Vancouver Island, B. C. Reached by the Island Highway from Victoria, or by rail to Duncans and auto stage to the head of the river at Cowichan Lake. A fine trout stream from March 2oth to November. It is one of the best canoe streams in the West.

CAMPBEll River, northeastern end of Vancouver Island. Reached by passenger steamers from Victoria or Vancouver. There is a fine automobile road - the Island Highway - from Victoria. Excellent trout fishing from March to November. Salmon fishing at the mouth of the river excellent from July to September I 5 th. Good hotel.

Sproat Lake, Somas River and Vicinity, Vancouver Island. Excellent trout fishing May to November. These excellent fishing waters may be reached by rail or the Island Highway from Victoria. Excellent hotels at Port Alberni, Sproat Lake and Cameron Lake.

Thompson River, on the line of the Canadian $\mathrm{Pa}$ cific Railroad from Kamloops to Ashcroft affords excellent trout fishing immediately following high water in July and from then to November.

Kootenay River and Lake, reached from Nelson,

B. C. Trout at any point on the river from the 
outlet of Kootenay Lake to the great pools below Bonnington Falls, June to November. Good hotels at Nelson and Proctor, and the Canadian Pacific Fishing Lodge at Bonnington Falls.

There are many attractive trout lakes in the vicinity of Kamloops, Ashcroft and Clinton and the streams and lakes near Fort George and along the line of the Grand Trunk Pacific Railroad afford excellent trout fishing from June to November. 


\section{CANADIAN FISHING WATERS}

Who of the fishing clan have not had the desire to make a fishing trip into the Canadian woods, along the lakes and streams of that land famed for its fishing. From coast to coast there are thousands of good fishing points in that land of delight to the outer. I have made a selection of excellent fishing waters from the great salmon streams the Miramichi and the Cain's River in New Brunswick to the lakes around Kamloops, British Columbia where the rainbow and cutthroat trout put up a wonderful fight in these cold waters of the mountains, with stops here and there across the continent such as the French River, Kawartha Lakes and Lake Penache of Ontario, Lake Kipawa and Lake Edward in Quebec and the world famous Nipigon where the speckled trout grow to staggering size, not forgetting the great stretch of rainbow trout fishing in the St. Mary's River rapids at Sault Ste. Marie.

Banff And Lake Louise, Alberta. Lakes and streams of this mountain region generously stocked with cutthroat, Dolly Varden, bull and lake trout. Good fly fishing in season. Informa- 
tion from the Brewster Transport Co., Banff, Alta.

BLIND River, Ontario. Black bass, pickerel and pike, muscalunge and salmon trout around islands in North Channel of Georgian Bay. Information from American Hotel.

Bonny River, New Brunswick. Splendid speckled trout fishing in the numerous lakes and streams of the district. Information from T. A. Sullivan, hotel and camp proprietor, Bonny River, N. B.

Bristol, New Brunswick. Salmon and speckled trout fishing on North Branch and Main Southwest Miramichi. Information from Mr. Murdock Mackenzie, Biggar Ridge, N. B., who has well equipped sporting camps.

CaIN's River, New Brunswick, reached via Fredericton. First class fishing for salmon and speckled trout. Information from Mr. W. Harry Allen, Penniac, N. B., who has control of the fishing rights on this river.

Desbarats, Ontario. Black bass, pickerel and pike. Speckled trout in some of the inland lakes. Information from J. R. Marshall \& Co., or W. J. Kellogg, Desbarats, Ont.

French River District, Ontario, Station, French River. First class muscalunge, large and smallmouth bass, pickerel and pike fishing. Information from A. L. DuBois, DuBois' Sportsman's Camp, Bigwood, Ont. 
Digby, Nova Scotia. Deep sea fishing. Good speckled trout fishing within few miles. For information apply H. A. P. Smith, Game Warden, Digby, N. S.

JACKFIsH, Ontario. Best of speckled trout fishing in Steel River and other streams within short distance along shore of Lake Superior. Also rainbow and salmon trout in Steel River and Mountain Lake. Information from Wm. Fraser, Jackfish, Ont.

Kamloops, British Columbia. Unexcelled fishing for rainbow and cutthroat trout in Fish, Paul and Penanton Lakes. Other varieties of trout in different lakes and streams of district. Information from Secretary, Board of Trade, Kamloops, B. C.

Kawartha Lakes, Ontario. Reached from east via Peterboro, from west via Bobcaygeon. Chiefly muscalunge and bass fishing. Information from Empress Hotel, Peterboro, Rockland House, Bobcaygeon.

Kedgemakooge Lake, Nova Scotia. Station Annapolis Royal, distant 35 miles. Speckled trout in Kedgemakooge Lake and tributary waters. Fine canoeing. Information from Manager, Kedgemakooge Rod and Gun Club, Annapolis, N. S.

KIPAWA, Quebec. Station for Lake Kipawa and tributary chain of lakes and streams. Lake trout, 
pike and pickerel in Lake Kipawa. Capital speckled trout fishing in certain waters of district. Information from Viets \& Clark, Outfitters, Kipawa.

LABELle, Quebec. Speckled and red trout in waters within any range. Information from Postmaster, Labelle, Que.

LAKE EDWARD, Quebec. Fine speckled trout fishing in Lake Edward and multitude of smaller lakes and streams of district. Information from Robt. and G. K. Rowley, Laurentide House, Lake Edward, Que., who operate string of sporting camps throughout territory.

LAKe of Woods District, Ontario. Principal gateway, Kenora. Muscalunge, small-mouth bass, lake trout, pickerel and pike. Wonderful canoe trips. Information from Secretary, Board of Trade, Kenora, Ont.

Lake Penache, Ontario. Station Whitefish. Remarkably fine bass fishing; also lake trout, pickerel and pike. Information from Dr. F. C. Frank or Dan Sheehan, Whitefish, Ont., who operate sporting camps.

Megantic, Quebec. Small-mouth bass, lake trout and speckled trout in Lake Megantic and adjacent waters. Information from Proprietor Union House or Queens Hotel, Megantic, Que.

Missanabie, Ontario. Speckled trout in nearby streams. Small-mouth bass, pickerel, pike and 
salmon trout in lakes within easy reach. Splendid opportunities for canoe cruising. Information from Hudson's Bay Co., Missanabie, Ont.

Nipigon, Ontario. Station for Nipigon River, world renowned for size and fighting quality of its speckled trout. Fly fishing good during July and August and up to close of season, September fourteenth. Small-mouth bass in Bass Lake, connected by creek with the Nipigon River I 2 miles up. Information from Hudson's Bay Co., or Wm. McKirdy \& Sons, Nipigon, Ont.

Nominingue, Quebec. Speckled or red trout in nearly all lakes of the locality. Information from A. Huot, Game Keeper and Fishery Overseer, Nominingue, Que.

Perth and Plaster Rock, New Brunswick. Going in stations for Tobique River system of waterways. Notably good salmon and speckled trout fishing. Information from Wade \& Knapp and Percy B. Falding, Perth, Ogilvy Bros., Oxbow, B. S. Moore and Chas. Cremin, Fredericton, N. B., all of whom operate camps in this territory. Point Au Baril (Georgian Bay), Ontario. Small mouth bass, muscalunge, pickerel, pike and salmon trout fishing among the islands of this district. Information from Manager, Ojibway Hotel, Ojibway Island P. O., Ont.

Ste. Agatge, Quebec. Station for Lakes Archambault and Ouareau and numerous smaller lakes, 


to

N

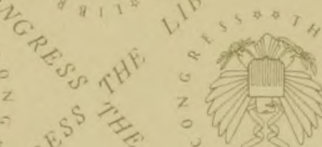

s

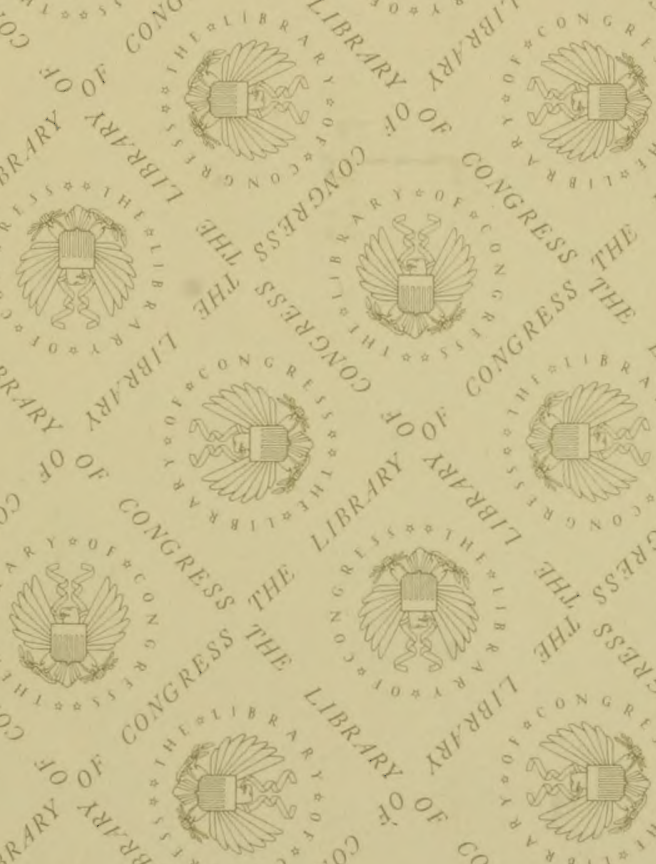

.

$100^{\circ}$

a for

at

(1iv)

"
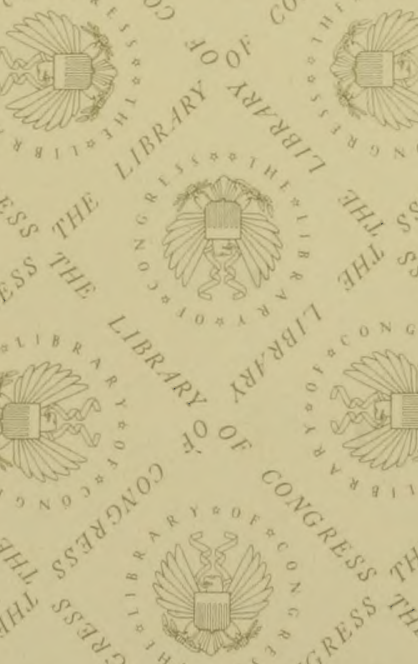

th?

a) $35^{5}=0$ 
LIBRARY OF CONGRESS 